\title{
REVISION OF THE PENNSYLVANIAN FLORA FROM VAL SANAGRA IN WESTERN PART OF THE SOUTHERN ALPS (ITALY)
}

\author{
Josef Pšenička ${ }^{1}$, Stanislav Opluštil ${ }^{2}$, Ausonio Ronchi ${ }^{3}$ \& Zbyněk Šimůnek ${ }^{4}$ \\ ${ }^{1}$ Palaeontology Department, West Bohemian Museum in Pilsen, Kopeckého sady 2, 30100 Plzeň, Czech Republic; \\ jpsenicka@zcm.cz \\ 2 Charles University in Prague, Faculty of Science, Albertov 6, 12843 Praha 2, Czech Republic; oplustil@natur.cuni.cz \\ ${ }^{3}$ Dipartimento di Scienze della Terra e dell'Ambiente, Universita di Pavia, Via Ferrata 1, 27100 Pavia, Italy; \\ ausonio.ronchi@unipv.it \\ ${ }^{4}$ Czech Geological Survey, Klárov 3/131, 11821 Praha 1, Czech Republic; zbynek.simunek@geology.cz
}

\begin{abstract}
The Pennsylvanian flora from the Alpe Logone/Val Sanagra locality in the Western Lombardy (Southern Alps, Italy) last underwent a taxonomic study in the mid 20th century. The main problem is generally poor preservation of the plant remains, which makes their identification problematic. Despite this, the authors have identified 43 fossil species from this locality. Based on the sedimentary context of this paleoflora, we assume that the Val Sanagra sediments were deposited in a continental setting, in a fluvial environment with a well-developed and vegetated floodplain where where clastic substrates would locally and occasionally change into peat swamp. The common presence of rhytidolepis and sub-rhytidolepis sigillarias, as well of Eusphenopteris neuropteroides, Lobatopteris miltonii, Mariopteris latifolia, Paripteris linguaefolia, Pecopteris microphylla, Alethopteris sp. (cf. grandinii) indicates that the flora from the Val Sanagra locality spans the interval between the Duckmantian and Bolsovian (middle Moscovian), and thus represents one of the oldest Pennsylvanian floras of the Southern Alps.
\end{abstract}

Key words: Pennsylvanian, fossil flora, Val Sanagra, Italy, Southern Alps

\section{INTRODUCTION}

The Pennsylvanian Subsystem has among the best-known fossil floras described from many localities throughout the world, including Europe. Nevertheless, Pennsylvanian floras from Italy remain at the periphery of interest of palaeobotanists because of being scattered in only a few localities which often represent tectonic units without clear stratigraphic and paleogeographic context, as well as providing remains that are not always well-preserved. Despite of this, the Pennsylvanian floras of Italy could play an important role when reconstructing the Late Carboniferous environments and paleogeography of this part of Europe, which are masked by strong Alpine overprint. Outcrops of terrestrial sediments, which have yielded Pennsylvanian floras, occur in different parts of Italy, especially in the regions of Western Lombardy, Canton Ticino, the Carnic Alps, Tuscany, and south western, central and south eastern Sardinia (Ronchi et al., 2012).

This paper deals with a revision of the Pennsylvanian flora from the Alpe Logone/Val Sanagra lo- cality (Figures 1,2) in the Western Lombardy (Southern Alps, Italy) which was first discovered in the mid 20th century. A rich collection of about 2000 specimens is now stored in the Museo Civico di Storia Naturale (Milan), and a minor but significant additional collection is in the Museo Etnografico e Naturalistico Val Sanagra (Grandola ed Uniti, Como).

The first report on Carboniferous macrofloras from this locality came from Magnani (1946), who discovered impressions and casts of Calamites Suckow ex Sternberg, Sigillaria Brongniart and Lepidodendron Sternberg. In the mid 20th century, Silvio Venzo and Luigi Maglia (Venzo and Maglia, 1947; Venzo, 1951) collected more than 2000 leaf compressions and impressions from the anthraciferous and silicified beds in Val Sanagra and Val Cavargna at Alpe Logone. These authors described, but never illustrated, about 22 genera and 75 species belonging to the sphenopsids (Sphenophyllum Brongniart, Calamites, Asterophyllites Brongniart, Annularia Sternberg), lycopsids (e.g., 


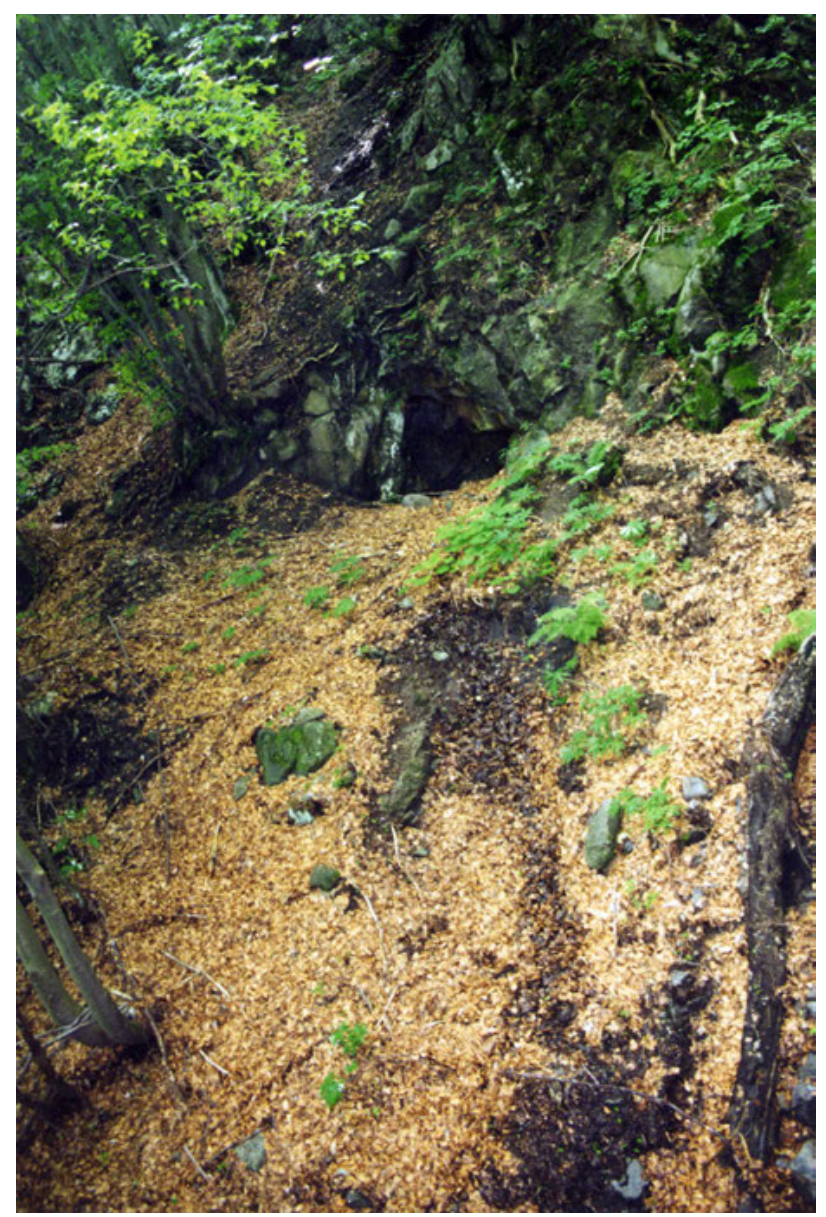

Figure 1. Entrance into one of the two anthracite quarries still existing in Val Gariasca (a small tributary valley of the main Val Sanagra) and exploited around the first half of the 20th century.

Lepidodendron, Knorria Sternberg, Lepidophyllum Brongniart, Sigillaria, Stigmaria Brongniart or Ulodendron Rhode), cycads, cordaitaleans, ferns (e.g. Pecopteris Brongniart) and pteridosperms (e.g. Mariopteris Zeiller, Neuropteris Brongniart, Linopteris Presl). Poorly preserved ribbed fragments of Sigillaria were also reported from the arenaceous layers.

Venzo and Maglia (1947) ascribed this flora to the late Westphalian (Westphalian C/ Middle Moscovian) and consider the flora of the Alpe Logone/ Val Sanagra to be slightly older than the flora from the Manno Conglomerate in Ticino, attributed to the early Stephanian by Sordelli (1896). Some years later, Venzo (1951) attributed the Val Manno flora (in agreement with Jongmans 1960) to the Westphalian B-C transition (early Moscov- ian) and therefore considered it older than the Alpe Logone/Val Sanagra flora. Recently, Pittau et al. (2008) found and described very rich late Westphalian-early Stephanian palynomorph associations in the Bedero locality (Luino, eastern side of Maggiore Lake, W Lombardy). On the basis of a review of the old papers, these authors assigned both the Logone and Manno's macrofloristic assemblages to the Moscovian (Bolsovian) or to the lower Moscovian (Duckmantian-Bolsovian) transition.

This paper revises all the accessible material from the Alpe Logone/Val Sanagra locality, identifies individual species and results based on a new identification of the plant species.

\section{GEOLOGICAL BACKGROUND}

Sparse and thin continental Pennsylvanian successions crop out in the western Southern Alps (Figure 2), to the west of Lake Como (VaresottoLuganese area), across the border between Italy and Canton Ticino (Switzerland).

These deposits are the product of the erosion of the Variscan mountain chain and occur generally pinched as tectonic slices along major tectonic lines or in stratigraphic non-conformity above the metamorphic basement (Figure 3).

The age of all these Upper Palaeozoic sedimentary successions, scattered over a wide area between Lake Como, Lake Maggiore and Ticino, has

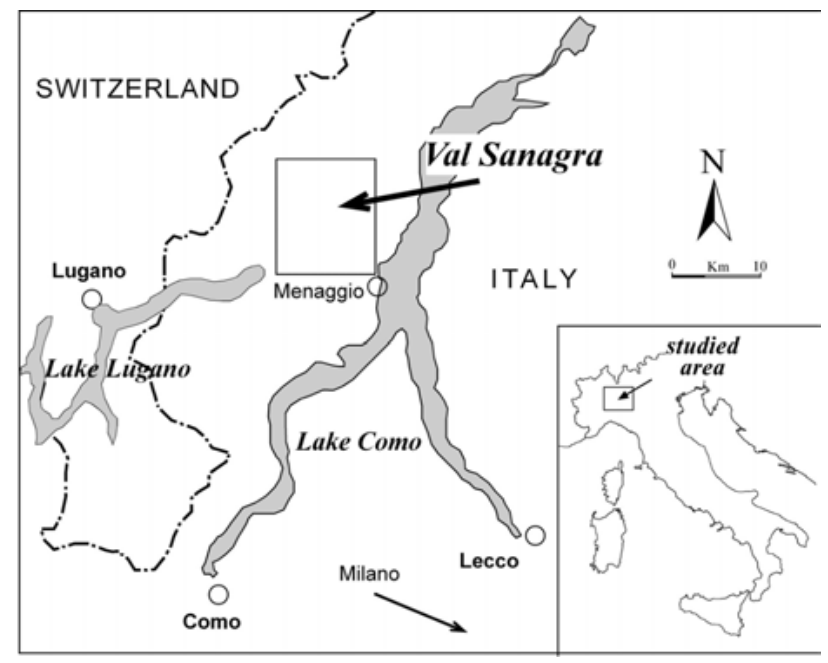

Figure 2. Location of the Val Sanagra/Alpe Logone Pennsylvanian plant fossil bearing deposits in the Western Southern Alps. 


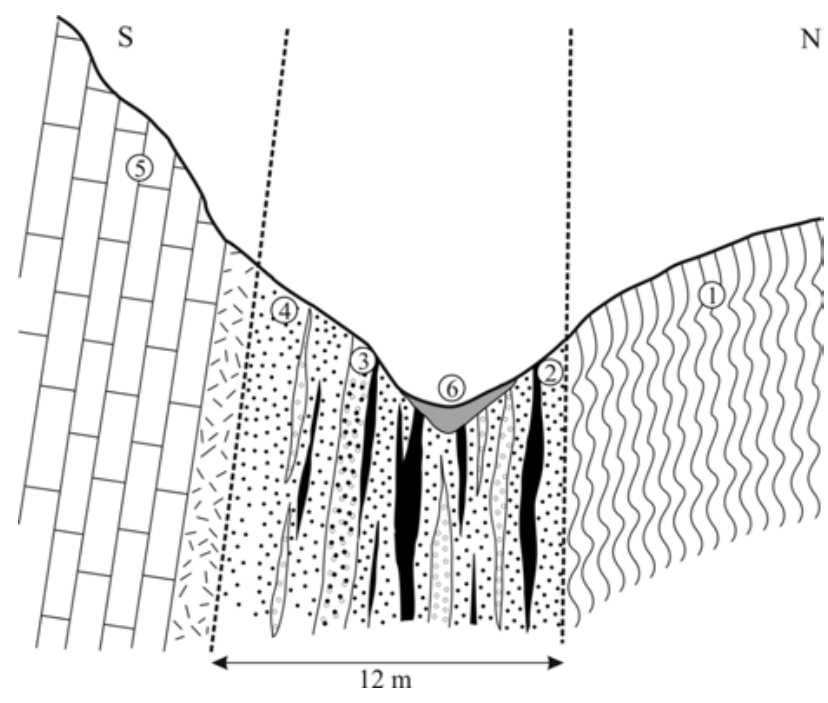

Figure 3. Geological sketch section of the Pennsylvanian to Ladian succession on the ravine of Val Sanagra-Logone, $W$ of Lake Como (from Venzo \& Maglia, 1947, mod). 1. Metamorphic basement cloritic mica shists, 2. Transgressive conglomerates and sandstones, with coal seams, rich in plants 3. Layer of a porphyritic conglomerates $(0.70-2 \mathrm{~m})$; 4. Coarse-grained sandstone, poorly fossiliferous $(3 \mathrm{~m})$; 5. Triassic Dolostones, brecciated at the bottom; 6. Mine debris, with anthracitiferous and fossiliferous shists.

long been debated as being between middle Westphalian and Stephanian (i.e. Moscovian/Kasimovian) (e.g. Lehner, 1952; Venzo and Maglia, 1947; Stadler et al., 1976; Casati, 1978; Gaetani et al., 1986).

Among the main localities, Val Sanagra (or more precisely Val Gariasca, near Alpe Logone) and secondarily Val Cavargna close to western side of Lake Como, were the ones which yielded the richest fossil floras. A detailed description on historical findings as well as the exploitation of the small anthracite mines can be found in Selva (2009).

The thickness of the fine to coarse-grained clastic deposits (Figure 3) varies from missing to $15 \mathrm{~m}$ (Venzo and Maglia, 1947).

\section{MATERIAL}

All fossil plant remains presented in this paper have been studied from collections stored in the Museo Civico di Storia Naturale (Milan) and also in the Museo Etnografico e Naturalistico Val Sanagra (Grandola ed Uniti, Como).

Although the studied fossils are preserved in a wide spectrum of lithologies ranging from con-

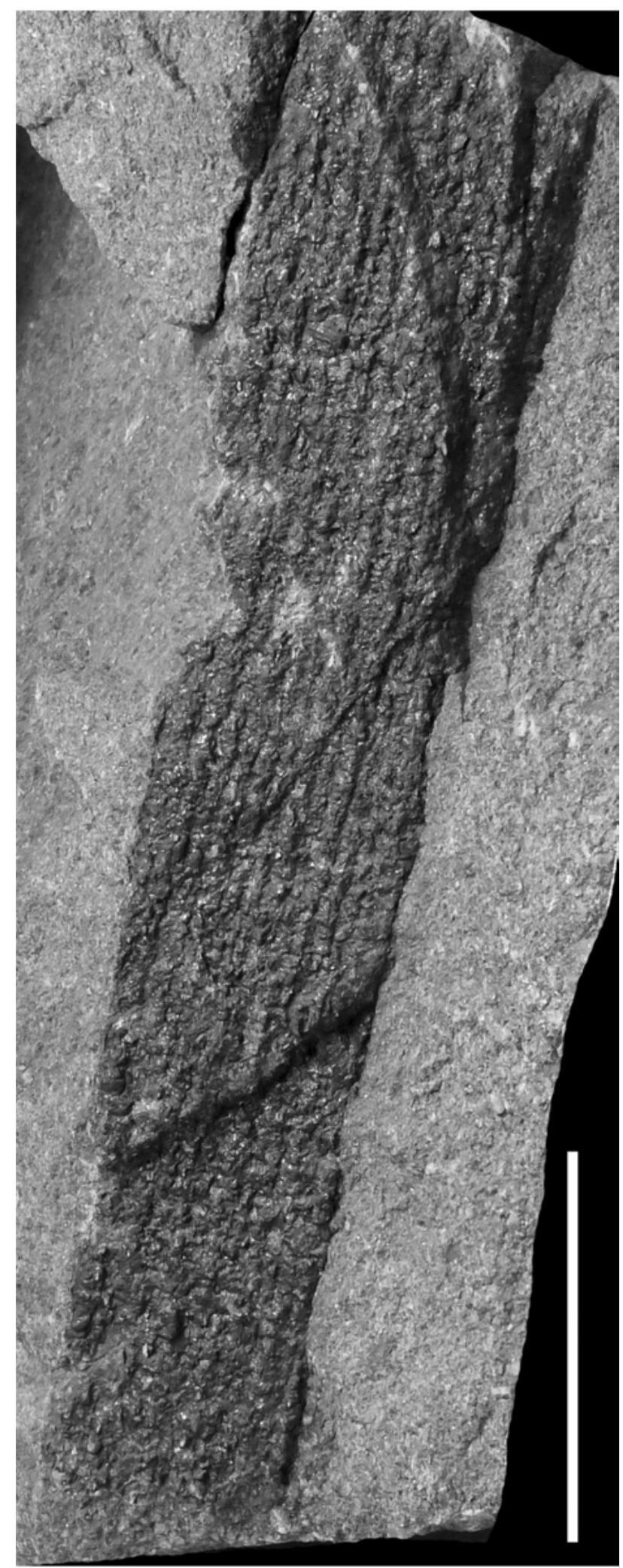

Figure 4. Syringodendron sp. preserved in the fine-grained biotite-rich sandstones. Scale bar is $100 \mathrm{~mm}$. 


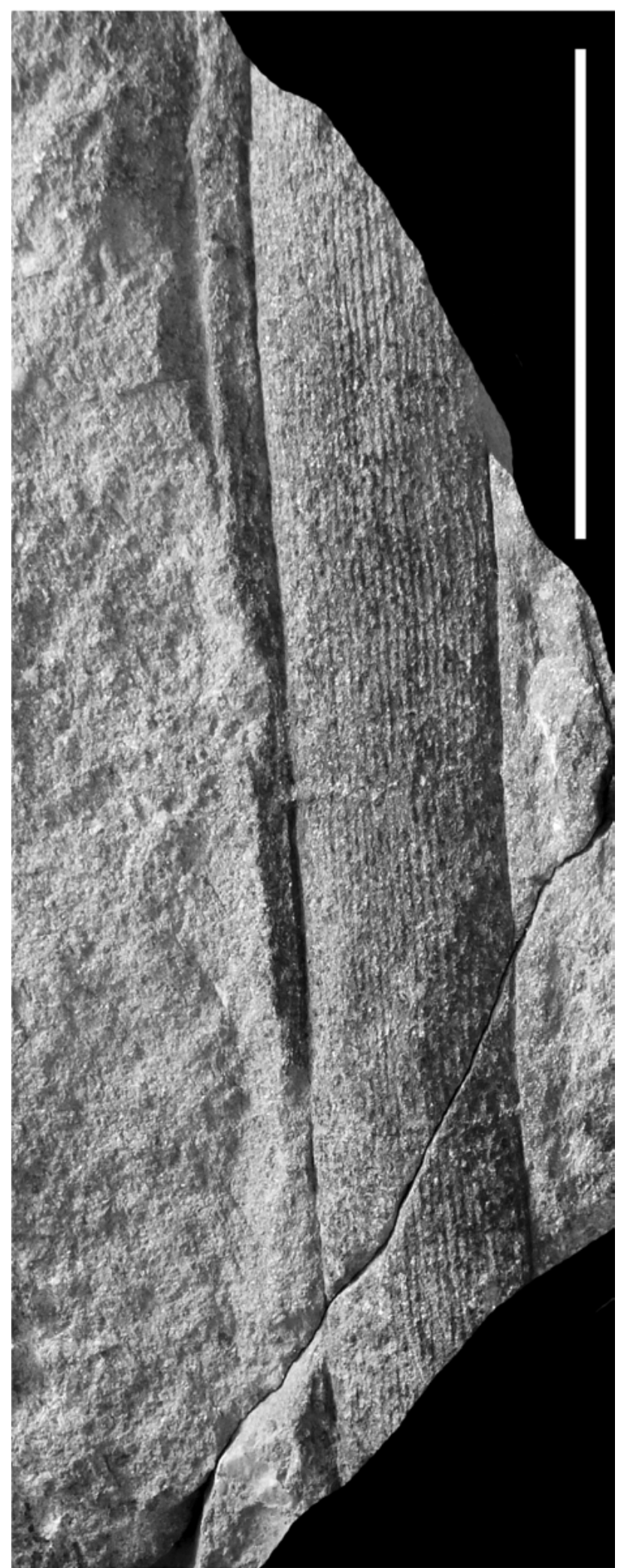

Figure 5. Calamites sp. preserved in the coarsegrained feldspatic sandstone. Scale bar is $100 \mathrm{~mm}$. glomerates and feldspatic sandstones to mudstones, they dominantly occur in fine-grained sediments. The specimens are mostly preserved in dark grey to nearly black, massive to poorly bedded or laminated micaceous siltstone, locally with a clay admixture and/or roots, and mostly comprise lycopsid appendices. Also identified were rare stigmarian axes. Fossils are either scattered or often concentrated on particular bedding planes as drifted fragments, usually composed mostly of isolated linopteroid pinnules, calamites axis or isolated lycospid (mostly sigillarian) leaves. Siltstones often grade into grey fine-grained biotiterich sandstones sometime with silty laminas. They preserve mostly pteridosperm or cordaites axes, or remains of decorticated (ribbed) sigillarian stems (Figure 4). The same fossils can be occasionally preserved in even coarser facies represented by coarse-grained feldspatic sandstones to fine grained conglomerates (about $3 \mathrm{~mm}$ grains of quartz and feldspar). These lithologies preserve mostly sphenopsid stems (Figure 5).

High coal rank, anthracite-coal deposit, precluded usage of any maceration techniques. In addition, some fossils are tectonically deformed. They are preserved as compressions or impressions (adpressions); some of them are rather "shadows" preserving the outline of former fossil remains. Also compressions are often poorly preserved, especially foliage remains which makes their species identification complicated, or even impossible. Dominating among plant fossils from Val Sanagra are unidentifiable axes of pteridosperms and/or cordaitalean plants, decorticated sigillarian stems, isolated linopteroid pinnules and calamites stems. Subordinate are remains of lycopsids and foliage of ferns and pteridosperms.

\section{SYSTEMATIC PART}

\section{Division Lycopsida}

Lycopsid remains comprise a significant part of the Val Sanagra collection, although most of them are represented only by partly decorticated sigillarian stems which exhibit pronounced vertical ribs some of them with rows of double elliptical scars of parichnos strands typical of Syringodendron Sternberg. Specimens preserving the outer surface with leaf scars assignable to the genus Sigillaria are much less common, although several relatively well-preserved specimens were found 
in the collection. These can be attributed to several species described below. Common, but occurring usually separately from stems are isolated long, single-veined grass-like lycopsid leaves, about 4 $8 \mathrm{~mm}$ wide, are attributed to Cyperites Lindley and Hutton, a fossil genus which is generally thought to represent compressed sigillarian leaves. These leaves are mostly preserved in the finest facies where they are associated with isolated linopteroid pinnules or foliage fragments of ferns and pteridosperms. Remains of other lycopsid genera are much less common compared to Sigillaria, and are represented by few specimens of Lepidodendron, Lepidophloios Sternberg and perhaps Bothrodendron Lindley et Hutton. Also identified were decorticated lepidodendrid stems represented by a few specimens of the Knorria and Aspidiariopsis type of preservation. Fertile organs of lycopsids are very rare and only Lepidocarpon majus sporophyll remains have been identified. Underground organs are represented by common appendices and few specimens of Stigmaria. No subarborescent to herbaceous forms of lycopsids have been identified in the studied material.

\section{Order Lepidodendrales}

\section{Family Sigillariaceae}

Genus Sigillaria Brongniart, 1822

Species Sigillaria rugosa Brongniart 1828 (Plate I, Figs 1-6)

Three specimens which possess the scars on ribs separated by prominent straight furrows have been identified in the collections. The ribs are $8-$ $10 \mathrm{~mm}$ wide on specimen B1722 (Plate I, Fig. 2), about $12 \mathrm{~mm}$ on specimen B1740 (Plate I, Fig. 1) and up to the $16 \mathrm{~mm}$ on specimen B3539 (Plate I, Fig. 4). Leaf scars are nearly oval to slightly subtriangular with rounded lateral angles and only gently convex upper end. Some leaf scars still show lateral parichnos as linear markings with punctuate vein cicatricule in between, all situated at about one third down the leaf scar. Length of leaf scars varies mostly between 8 and $10 \mathrm{~mm}$ and width 4.5 and $5.5 \mathrm{~mm}$ (Plate I, Figs 3, 5), except specimen B1740 which possess leaf scars $12.5 \mathrm{~mm}$ long and $7.2 \mathrm{~mm}$ wide in the lower third of the scar length (Plate I, Fig. 6). The shape, however, is very similar to the other two specimens. Vertical distance between leaf scars also varies among specimens from $22 \mathrm{~mm}$ (B1740) to $30 \mathrm{~mm}$ (B1722, 3539). Surface between leaf scars is smooth (B1722, 1740) (Plate I, Fig. 3), however, specimen B3539 (Plate I, Fig. 5) displays fine vertically oriented closely spaced and slightly undulating lines along the ribs. In addition, lateral angles of the leaf scars give rise to two fairly prominent mildly undulating lines descending vertically to the leaf scar next below (Plate I, Fig. 5). Specimen B1722 is partly decorticated. These decorticated parts possess prominent ribs with vertically striated areas between them and markings indicating position of leaf scars (Plate I, Fig. 3).

Remarks: The specimens described above show the same shape and size of leaf scars, and their density and relatively poor ornamentation is typical for Sigillaria rugosa documented by Němejc (1951) or Crookall (1966) or as can be seen from original Brongniart drawing of the type specimen coming from Pennsylvania. S. rugosa can be compared with several other eurhytidolepis species such as S. voltzi Brongniart, S. cortei Brongniart or S. contracta Brongniart, some of them being considered as synonymous to $S$. rugosa by various authors (e.g. Deltenre, 1924; Crookall, 1966). $S$. rugosa is common in Duckmantian to lower Bolsovian (lower/middle Moscovian) strata of most coalfields in Europe and its precise stratigraphic range can vary slightly among basins. Consequently, this species is occasionally reported from Langsettian (upper Bashkirian) strata and Crookall (1966) mentioned it to be very rare even in the Asturian (upper Moscovian) of the Bristol and Forest of Dean coalfields in UK.

Species Sigillaria cf. inferior Weiss 1881 (Plate I, Fig. 7)

The only specimen (B1742) is a poorly preserved fragment of a ribbed bark with leaf scars. Furrows separating ribs are undulating and the distance between neighbouring ones varies from 3 to 5.5 $\mathrm{mm}$; the largest width is reached at the level of the leaf scar or slightly above it. Leaf scars are around $3.5-4 \mathrm{~mm}$ wide and $2 \mathrm{~mm}$ long, about 4.5 $\mathrm{mm}$ apart. Area between leaf scars appears smooth, however, this could be also due to preservation. Leaf scars are generally lenticular in shape, although some of them (Plate I, Fig. 7) seem to be sub-triangular with an upper angle and convex margin, thus being more bell-shaped and 
Folia vol. 46, No. 1-2, 2012

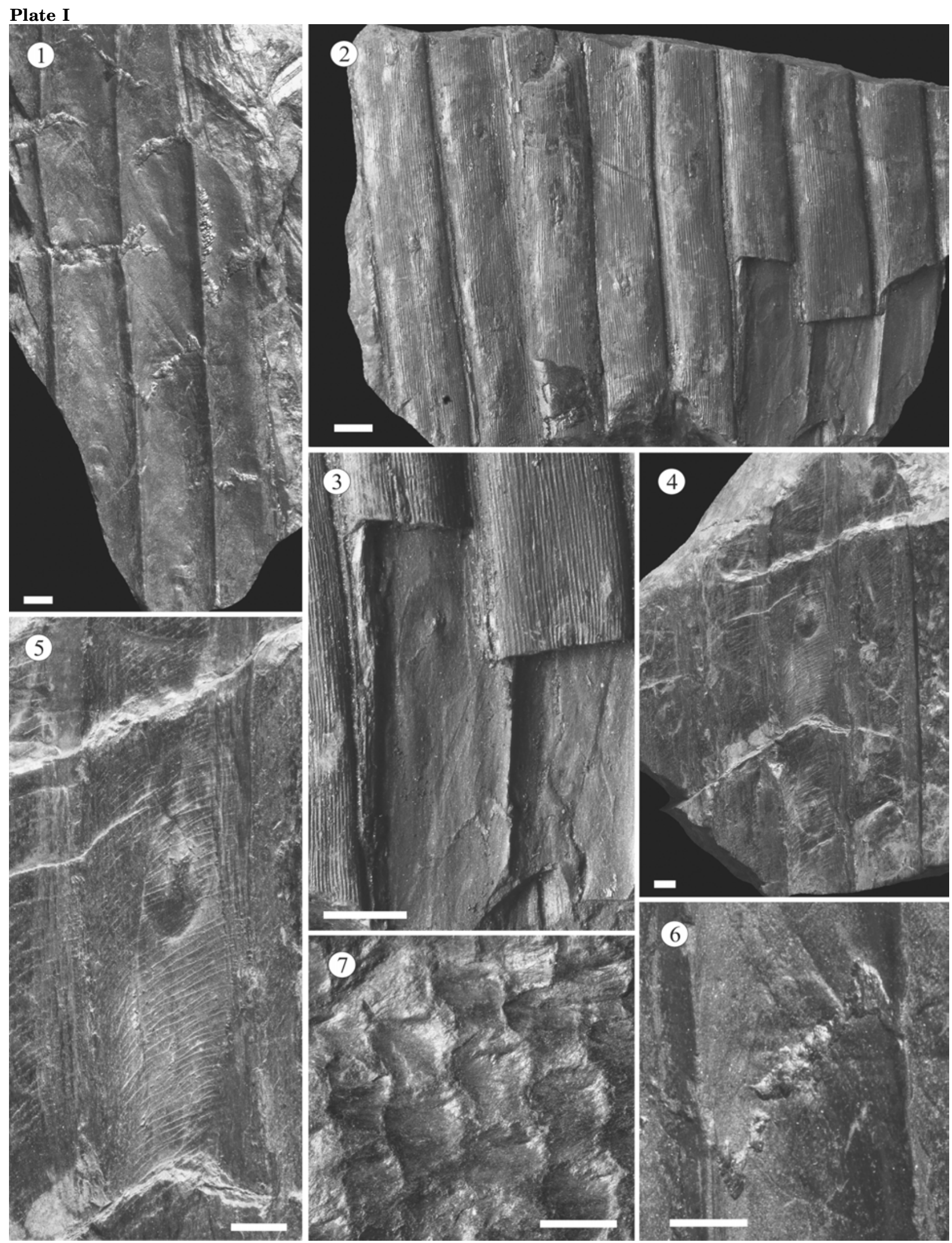


transversally asymmetrical. However, most leaf scars have only a convex upper margin. Pointed or linear impressions of parichnos tissues and/or vein in between are also seen on some leaf scars.

Remarks: The specimen B1742 can be compared with several species among which the most similar is $S$. inferior from the early middle Moscovian strata (Duckmantian) of the Upper Silesian Coal Basin. The Weiss species has similar size and density of lenticular to sub-hexagonal leaf scars and markedly undulating ribs. It possesses also transversally oriented wrinkles (striations) between leaf scars, which however are not observable on the Val Sanagra specimen. Another species which has to be taken into account when comparing with the above described specimen is S. canobiana Kidston 1903 from the Carboniferous of Scotland which is of similar size and shows undulating ribs but has generally more bell-shaped leaf scars. Comparison was also made with $S$. transversalis Brongniart (1828) originally described from Aachen coalfield (?Langsettian-Duckmantian) in NW Germany. This species has lenticular leaf scars of similar size as the specimen described here, but the ribs are nearly straight. Finally, the described specimen strongly resembles Sternberg's "Rhytidolepis ocellata" from lower Bolsovian strata of the Radnice Basin, Czech Republic. Both have undulating ribs, and smooth areas between lenticular to flat sub-triangular leaf scars. Němejc (1951) reinterpreted this Sternberg species, represented only by a single specimen, as $S$. pachyderma sensu Corda non Brongniart. S. pachyderma sensu Corda differs from the specimen described here mainly in having slightly undulating longitudinal wrinkles between the leaf scars. In any case, all the comparable sigillarian species are of the Rhytidolepis-type and are stratigraphically located to the Bashkirian and Moscovian (late Namurian to about early-middle Bolsovian).
Species Sigillaria cf. ovata Sauver 1848 (Plate II)

Two relatively well-preserved and partly decorticated specimens (B1769 and B1887) have been assigned to this species. The specimen B1769 preserves fragments of two associated bands (ribs) of bark situated at a low angle to each other. One of them is about $9.5 \mathrm{~mm}$ wide and smooth with leaf scar(s) that shows rather straight only slightly convex upper edge and rounded lower edge and both lateral angles (Plate II, Fig. 4). The scar is $6.3 \mathrm{~mm}$ long and $5.8 \mathrm{~mm}$ wide slightly below the middle of the scar length. The upper edge is $2.6 \mathrm{~mm}$ long. Although only one leaf scar is well preserved, the outline of the position of the second scar is identifiable which allows the distance between scars to be estimated at about $6.5 \mathrm{~mm}$. A vascular bundle and parichnos cicatricules are situated slightly above the mid of the scar length. The second bark band is $13.5 \mathrm{~mm}$ wide, vertically striated with preserved vascular bundle markings $14.5 \mathrm{~mm}$ apart. No leaf scar is present, which together with vertical striations across the whole rib indicates that it is a decorticated part of bark (Syringodendron stage).

The second specimen (B 1887) is split into several fragments which preserve several ribs of sigillarian bark, partly with leaf scars, partly without them. Ribs are all about $13.0-18.5 \mathrm{~mm}$ wide and are either smooth or vertically striated (Plate II, Fig. 1). Those which are smooth possess leaf scars which have a straight or nearly straight (or very gently convex) upper edge about $2.8 \mathrm{~mm}$ long, and rounded lower edge and lateral angles. The leaf scars of one fragment are $6.5 \mathrm{~mm}$ wide and $5.0 \mathrm{~mm}$ long (Plate II, Fig. 1), however bark bands on Plate II, Fig. 5 have leaf scars which are about $10 \mathrm{~mm}$ wide and $8.5 \mathrm{~mm}$ long. Vascular bundle and parichnos markings are in the upper half of the scars. Striated (?decorticated) bands (Plate II, Figs 1, 3,6) display outline of leaf scars similar to

\section{Plate I}

1) Sigillaria rugosa; Museo Civico di Storia Naturale (Milan); specimen B1740; scale bar 5 mm; 2) Sigillaria rugosa; Museo Civico di Storia Naturale (Milan); specimen B1722; scale bar 5 mm; 3) Sigillaria rugosa; Museo Civico di Storia Naturale (Milan); specimen B1722; scale bar $5 \mathrm{~mm}$; 4) Sigillaria rugosa; Museo Civico di Storia Naturale (Milan); specimen B3539; scale bar $5 \mathrm{~mm}$; 5) Sigillaria rugosa; Museo Civico di Storia Naturale (Milan); specimen B3539; scale bar $5 \mathrm{~mm}$; 6) Sigillaria rugosa; Museo Civico di Storia Naturale (Milan); specimen B1740; scale bar $5 \mathrm{~mm}$; 7) Sigillaria cf. inferior; Museo Civico di Storia Naturale (Milan); specimen B1742; scale bar 5 mm. 
Folia vol. 46, No. 1-2, 2012

Plate II
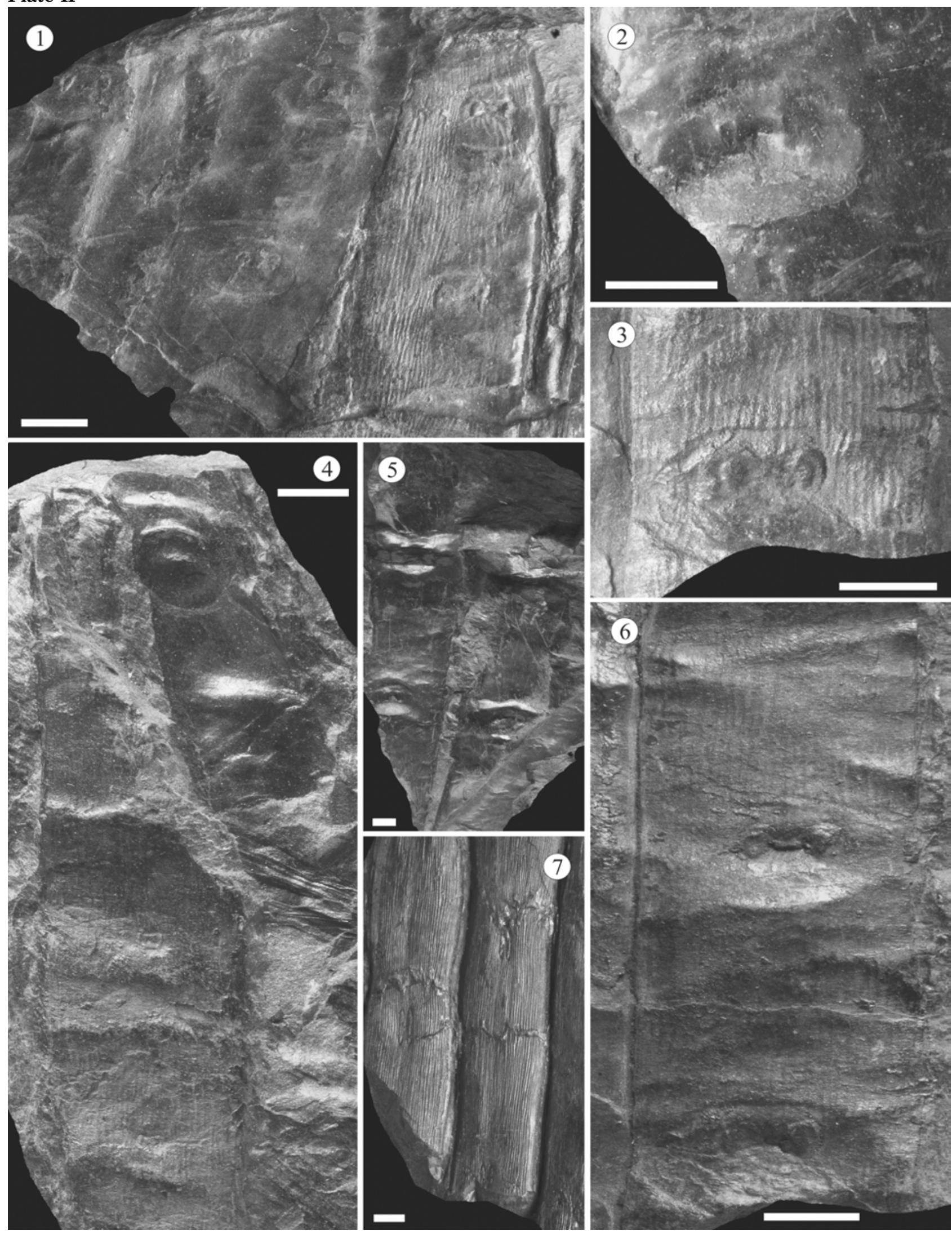

7

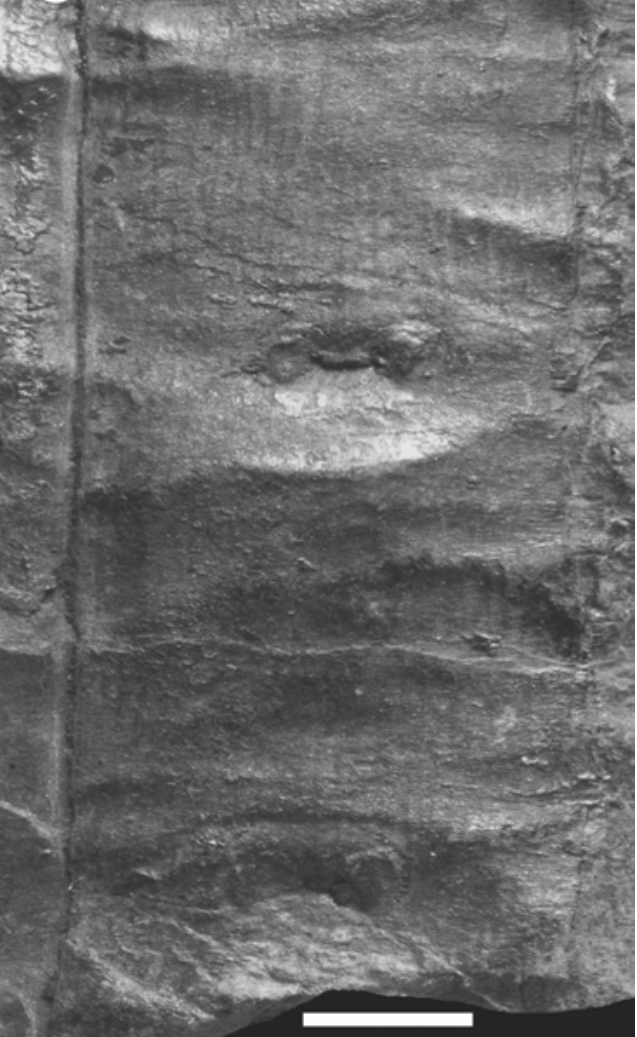


those of smooth bands also with apparent parichnos and vascular bundle markings. The scar figured on Plate II, Fig. 3 displays a concave upper edge.

Remarks: The specimens described here can be compared with $S$. ovata Sauver and $S$. principis Weiss. Both have relatively wide pear-like leaf scars with lateral and rounded lower edges. However, S. principis has a prominent arched transverse mark above the leaf scar and subvertical lines running down from the lateral angles which have not been observed in the specimens described here. Therefore we assigned them to $S$. ovata, although with some uncertainty resulting from the upper edge, which is more straight in the Val Sanagra specimens. S. ovata is a fairly common species in most basins of the belt of paralic coalfields in western and central Europe between the Langsettian to Duckmantian, but becomes very rare in Bolsovian and Asturian floras.

Species Sigillaria tessellata Brongniart 1828 (Plate III, Figs 1, 2)

Only a single specimen shows two straight ribs separated by gently flexuous furrows. The ribs are about $9-10 \mathrm{~mm}$ across. Leaf scars are hexagonal, occupying most of the rib width, about as wide as long or slightly wider, with lateral angles sub-angular to sub-rounded (Plate III, Fig. 2). Margins of scars are straight or slightly convex. Leaf scars are densely spaced separated only by prominent straight transversal furrow across the half of the rib width. Most of leaf scars show the position of the parichnos and vascular cicatricules, which are situated at about one third the way down the scar. Remarks: The specimen described here which is from the Museo Etnografico e Naturalistico Val Sanagra can be compared also with $S$. boblayi Brongniart, S. micaudi Zeiller and S. barbata Weiss. All the mentioned species have leaf scars of similar size and shape, especially in the case of $S$. boblayi. S. barbata has a slightly longer transversal furrow separating the leaf scars than the specimen described here. In any case, all the mentioned species occur in Langsettian to Duckmantian strata, being less common in strata of late Moscovian age.

Species Sigillaria cf. micaudi Zeiller 1886 (Plate III, Fig. 3)

One specimen in the Museo Etnografico e Naturalistico Val Sanagra consists of a fragment with two ribs showing several leaf scars separated along nearly the whole width of the ribs by a straight transversal furrow. Ribs are about $10 \mathrm{~mm}$ wide and separated by flexuous furrows. The transversal furrow is closer to the upper margin of the leaf scar than to the lower one. Leaf scars are hexagonal, slightly wider than long, and with rounded angles. Vascular and parichnos cicatricules are usually one third the way down the leaf scar.

Remarks: The specimen described here resembles strongly the specimen described above as $S$. tessellata, the only difference being that the leaf scars are slightly less densely spaced. Nevertheless this may be a result of a different position on the stem since the shape of leaf scars of both specimens is very similar. The stratigraphic range of S. micau$d i$ is comparable with that of $S$. tessellata.

Species ?Asolanus camptotaenia Wood 1860 (Plate IV, Fig. 1)

The specimen is a fragment of a bark with dense and slightly undulating vertical wrinkles which irregularly merge and/or split after some distance. Scars are not observable.

Remarks: The specimen is probably a poorly preserved bark of Asolanus camptotaenia, a sub-sigillarian lycopsid. This species has a very wide stratigraphic range and is known from at least the late Bashkirian to late Gzhelian.

Plate II - Sigillaria cf. ovata; Museo Civico di Storia Naturale (Milan)

1) Specimen B1887; scale bar 5 mm; 2) Specimen B1887; scale bar 5 mm; 3) Specimen B1887; scale bar 5 mm; 4) Specimen B11769; scale bar $5 \mathrm{~mm}$; 5) Specimen B1887; scale bar $5 \mathrm{~mm}$; 6) Specimen B1887; scale bar $5 \mathrm{~mm}$; 7) Specimen B1887; scale bar $5 \mathrm{~mm}$. 
Folia vol. 46, No. 1-2, 2012
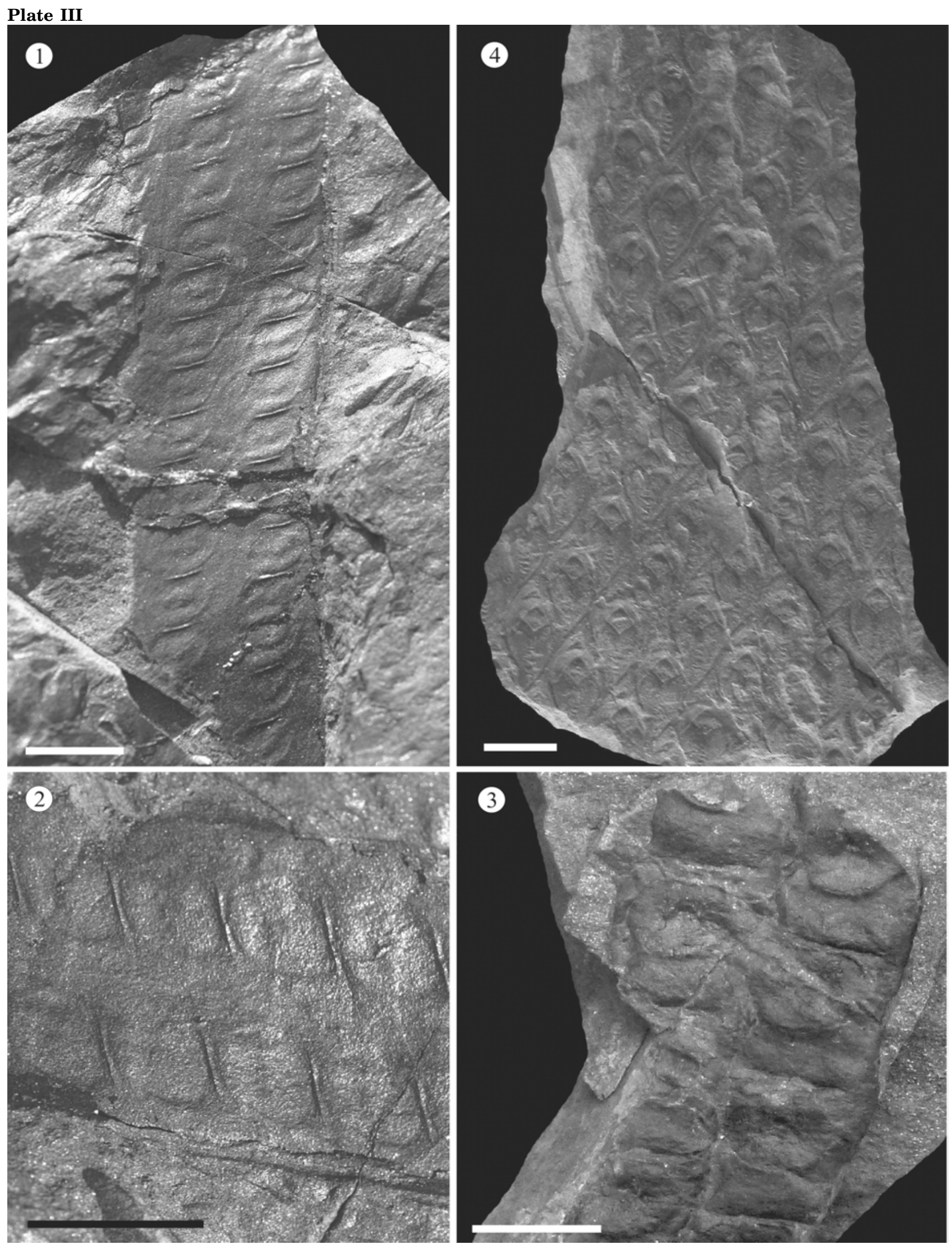


\section{Family Lepidodendraceae}

Genus Lepidodendron Sternberg 1820

Species Lepidodendron aculeatum Sternberg 1820 (Plate III, Fig. 4)

This species is represented by only a single specimen which is a fragment of a bark showing typical longitudinally and transversally asymmetrical leaf cushions with pointed upper and lower angles and rounded lateral angles. Below the leaf scar is a prominent keel with notches across. Diamondshaped leaf scars are as long as wide and some of them possess a vascular bundle and two parichnos imprints. Infrafoliar parichnos scars are present laterally next to the leaf scars.

Remarks: The preservation of the specimen is good enough to identify the main features typifying this species, and therefore its determination is reliable. This species is common from Early to early Middle Pennsylvanian of Europe and North America, and becomes very rare in the end of the Middle Pennsylvanian.

Species Lepidodendron cf. acutum Presl in Sternberg 1838 (Plate V, Fig. 4)

Several specimens are preserved as bark adpression. The specimen figured here shows narrow, slightly inflexed and longitudinally asymmetrical fusiform leaf cushions. They are about $18 \mathrm{~mm}$ long and $3-3.5 \mathrm{~mm}$ wide reaching their maximum width around half the way up the cushion. They display sharply pointed upper and lower angles and rounded lateral angles. The keel is smooth and only slightly raised. A leaf trace rather than a leaf scar can be seen about three quarters up the cushion. This represents a false leaf scar indicating that leaves were still attached to the stem; however leaves themselves are not preserved. No evidence of an infrafoliar parichnos is present. Remarks: The specimen represents the type of lepidodendrid species with fusiform leaf cushions and false leaf scars without infrafoliar parichnos.
The most common and widespread representative of this type is Lepidodendron acutum from early to middle Moscovian strata of Europe. This species corresponds in shape, size and smooth keel to here described specimen. A similar species, L. simile sensu Němejc (1947) non Kidston, from central and western Bohemia, possesses similar but usually a little smaller leaf cushions. However, it clearly differs from $L$. acutum in having much smaller and S-bent leaves. Because the leaves are not preserved in the described specimen, we leave its determination as uncertain.

\section{Species Lepidophloios sp.(Plate V, Fig. 5)}

A single, poorly preserved specimen shows the outline of slightly deformed rhombic and transversally symmetrical leaf cushions. These are about $16-17 \mathrm{~mm}$ wide and about $7-8 \mathrm{~mm}$ long. Their lower end is angular (about $120^{\circ}$ ) whereas the upper end is rounded. Lateral angles are both about $70-80^{\circ}$. Some of the leaf cushions display imprint traces above the lower end which might be a poorly preserved leaf scar.

Remarks: Poor preservation of the leaf cushions which are wider than longer allows only for a generic determination, although the size of leaf cushions suggests it probably belongs to some forms with larger leaf cushions especially $L$. laricinus Sternberg from Early to Middle Pennsylvanian strata of Euramerica.

\section{Species Halonia sp. (Plate IV, Fig. 1)}

The only specimen is about $20 \mathrm{~cm}$ long and about $6-6.5 \mathrm{~cm}$ wide branch showing small helically arranged "ridges" representing poorly preserved leaf cushion outlines. Since no other structure can be observed, it is assumed that the specimen was decorticated already prior the final burial in the sediment. Typical of this fossil genus is an oval $10 \times 12 \mathrm{~mm}$ large branch scar. Some shallow hollows elsewhere on the specimen may suggest the presence of other very poorly preserved branch scars.

\section{Plate III}

1) Sigillaria tessellata; the Museo Etnografico e Naturalistico Val Sanagra; scale bar $10 \mathrm{~mm}$; 2) Sigillaria tessellata; the Museo Etnografico e Naturalistico Val Sanagra; scale bar $10 \mathrm{~mm}$; 3) Sigillaria cf. micaudi; the Museo Etnografico e Naturalistico Val Sanagra; scale bar $10 \mathrm{~mm}$; 4) Lepidodendron aculeatum; Museo Civico di Storia Naturale (Milan); scale bar $10 \mathrm{~mm}$. 


\section{Plate IV}
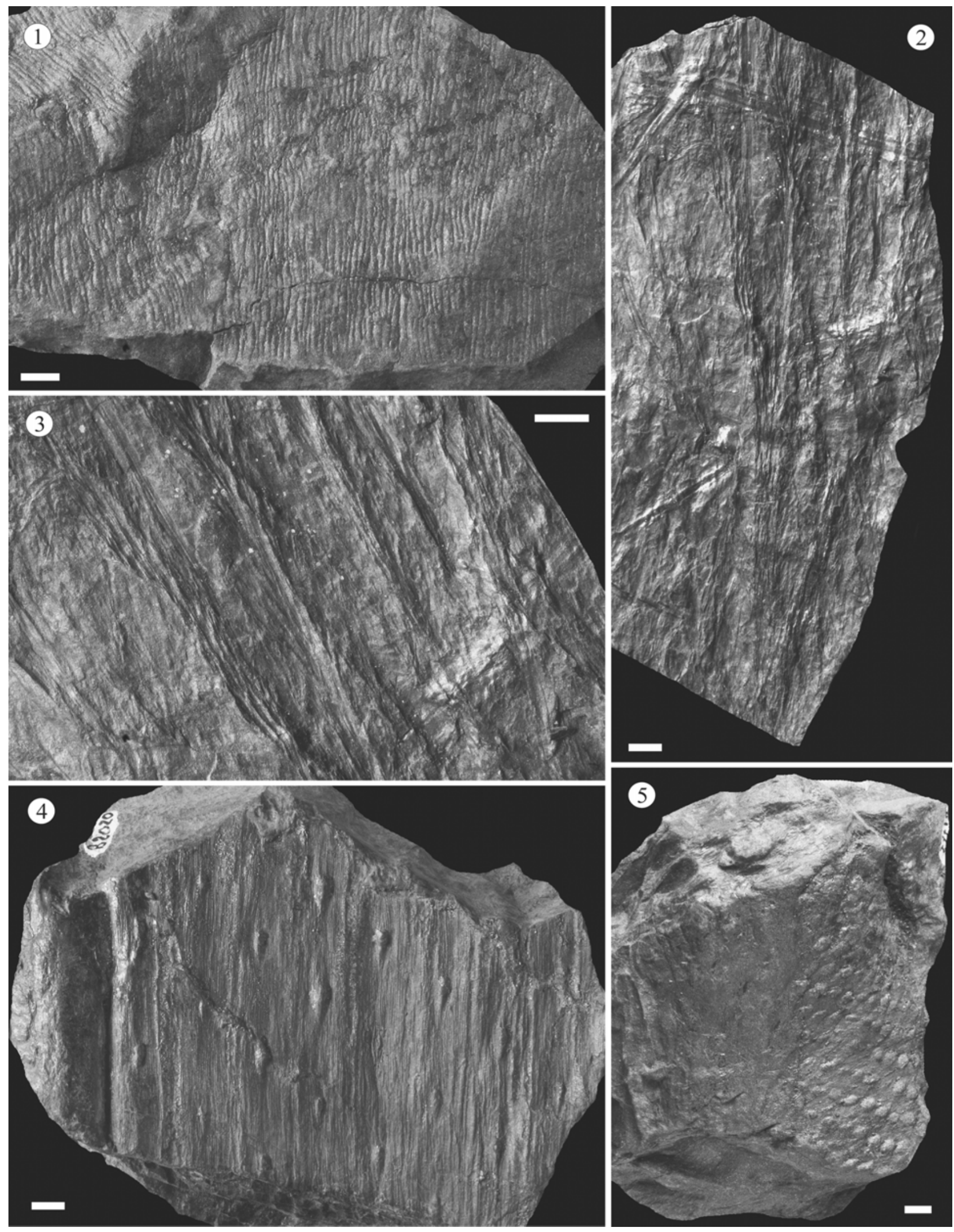
Remarks: Although the specimen is quite poorly preserved the clear presence of an oval branch scar is indicative of its attribution to the fossil genus Halonia sp. which is most commonly connected with Lepidophlois as the parent plant (e.g. Hirmer, 1927).

Species Lepidocarpon cf. majus (Brongniart) (Plate V, Figs 2, 3)

Two specimens represent fragments of the lamina part of a large sporophyll. It displays a pointed apex passing downward into a part with entire parallel sides. A midrib is traceable nearly up to the apical part of the lamina. The fragment, represent about the apical half of a sporophyll blade, is about $52 \mathrm{~mm}$ long and $12 \mathrm{~mm}$ wide.

Remarks: The size and shape of the lamina indicate that it belongs to the fossil genus Lepidocarpon Allen 1961, a large sporophyll bearing seedlike megaspore and produced by the genus of arborescent lycopsids, Lepidophloios (e.g. Bateman et al. 1992). Its large size further suggests that it most probably represents Lepidocarpon majus which is common throughout Early to Middle Pennsylvanian strata of Euramerica.

Genus Stigmaria Brongniart 1822

Species Stigmaria ficoides (Sternberg 1820) Brongniart 1822 (Plate V, Fig. 6)

The specimen figured is a fragment of the rhizophore of an arborescent lycopsid which displays oval (due to a strong postdepositional deformation) scars regularly arranged into a helix. The oval scars are about $6 \times 3 \mathrm{~mm}$ large with a small cicatrice in the middle. The scars are spaced about $6 \mathrm{~mm}$ apart.

Remarks: Although the preservation is poor and the specimen is only a small fragment, characteristic appendices scars allow for its generic determination as Stigmaria, most probably representing the most common species $S$. ficoides.
Species Knorria sp. (Plate IV, Figs 4, 5)

Several remains of deeply decorticated lepidodendrid stems of the Knorria (as well as Aspidiopsis) stage have been found in the museum collections. Two of them have been figured on Plate IV, Fig. 4 and show diamond shaped ridges arranged in to a helix. The space in between them is covered by vertically arranged straight but discontinuous low and narrow ridges or wrinkles. Another specimen (Plate IV, Fig. 5) shows helically arranged and densely spaced oval ridges, wider than long, probably as a result of deformation.

\section{Family Bothrodendraceae}

Genus Bothrodendron Lindley et Hutton

Species? Bothrodendron sp. (Plate IV, Figs 2, 3)

The specimen preserves several thin and poorly preserved leafy shoots (Plate IV, Fig. 2) with small short leaves thus resembling those of some representatives of the genus Bothrodendron. The shoots are about $7 \mathrm{~mm}$ long, $2 \mathrm{~mm}$ wide and slightly bent in an S-curve (Plate IV, Fig. 3). Representatives of the genus Bothrodendron are typical for Duckmantian to late Bolsovian strata of most European coalfields.

\section{Division Sphenopsida}

\section{Order Equisetales}

Family Calamitaceae

Genus Calamites Suckow

Species Calamites (Diplocalamites) carinatus Sternberg 1823 (Plate VI)

Calamites (Diplocalamites) carinatus is a common fossil at the Val Sanagra locality. The species is represented by casts of various widths which vary from $15 \mathrm{~mm}$ to more than $100 \mathrm{~mm}$. The distance between two nodes is possible to observe only in one specimen (B1887; Plate VI, Fig. 4); the other specimens only have one node preserved. Longitu-

\section{Plate IV}

1) Asolanus camptotaenia; Museo Civico di Storia Naturale (Milan); specimen B1999; scale bar 5 mm; 2) Bothrodendron sp.; Museo Civico di Storia Naturale (Milan); specimen B1686; scale bar $5 \mathrm{~mm}$; 3) Bothrodendron sp.; Museo Civico di Storia Naturale (Milan); specimen B1686; scale bar $5 \mathrm{~mm}$; 4) Knorria sp.; Museo Civico di Storia Naturale (Milan); specimen B1784; scale bar 5 mm; 5) Knorria sp.; Museo Civico di Storia Naturale (Milan); specimen B1772, scale bar 5 mm. 

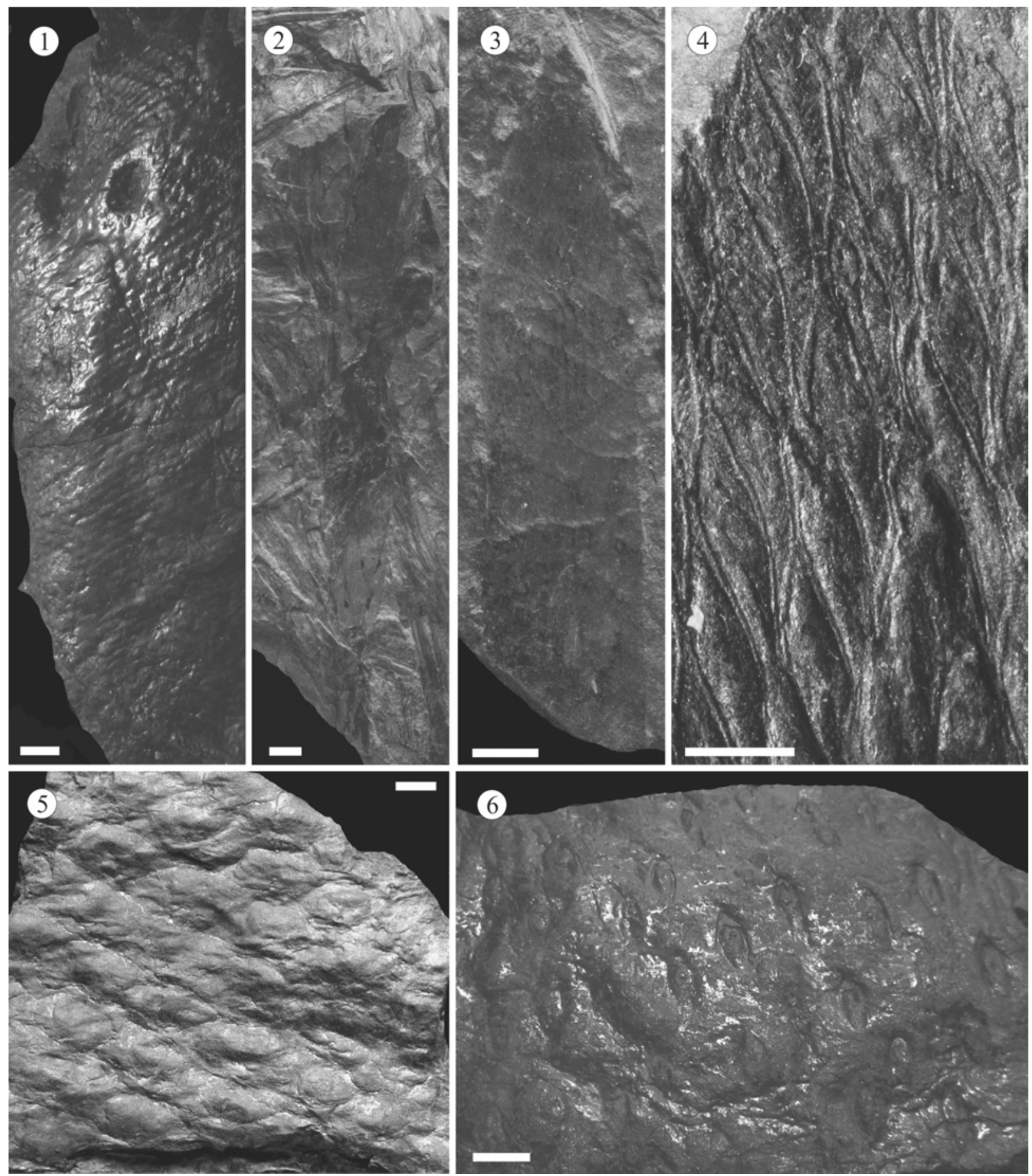

\section{Plate V}

1) Halonia sp.; Museo Civico di Storia Naturale (Milan); specimen B1747; scale bar $10 \mathrm{~mm}$; 2) Lepidocarpon cf. majus; Museo Civico di Storia Naturale (Milan); specimen B1766; scale bar $5 \mathrm{~mm}$; 3) Lepidocarpon cf. majus; Museo Civico di Storia Naturale (Milan); specimen B1587; scale bar $5 \mathrm{~mm}$; 4) Lepidodendron cf. acutum; Museo Civico di Storia Naturale (Milan); specimen B1787; scale bar 5 mm; 5) Lepidofloios sp.; Museo Civico di Storia Naturale (Milan); specimen B1924; scale bar $5 \mathrm{~mm}$; 6) Stigmaria ficoides; Museo Civico di Storia Naturale (Milan); scale bar $10 \mathrm{~mm}$. 

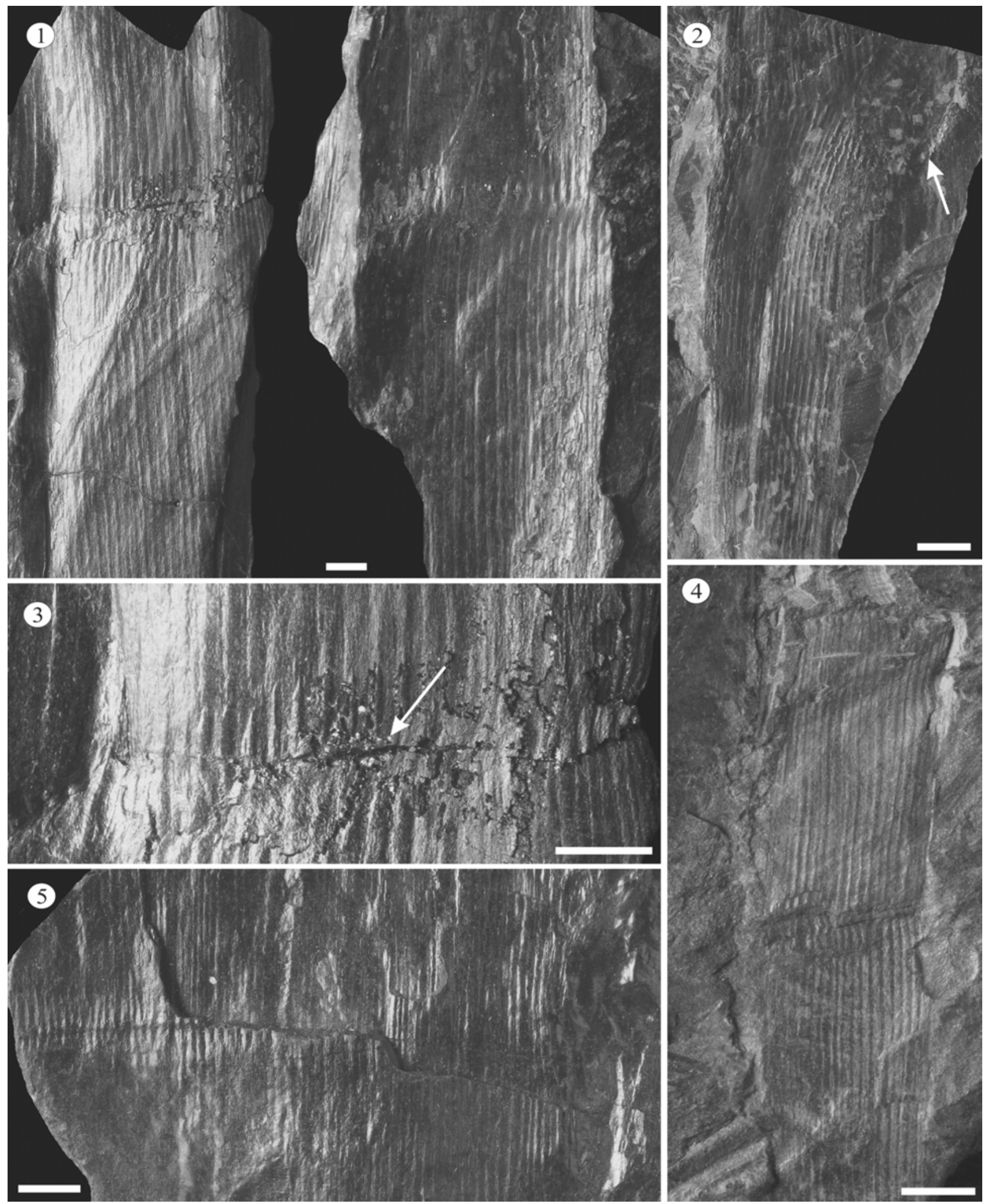

Plate VI - Calamites (Diplocalamites) carinatus; Museo Civico di Storia Naturale (Milan).

1) specimen B1974; scale bar $5 \mathrm{~mm}$; 2) specimen B1693; scale bar $10 \mathrm{~mm}$; 3) specimen B1974; scale bar $5 \mathrm{~mm}$; 4) specimen B1887; scale bar $5 \mathrm{~mm}$; 5) specimen B1619; scale bar $10 \mathrm{~mm}$. 
dinal canals are straight, $1-2 \mathrm{~mm}$ broad. The elliptic leaf scares are rarely seen in the nodal part. The leaf scars are 0.8 - $1.5 \mathrm{~mm}$ in diameter (Plate VI, Fig. 3 arrow). Specimen B1693 (Plate VI, Fig. 2 arrow) shows a round branch scar $22 \mathrm{~mm}$ in diameter. Remarks: This species has a large stratigraphic range from Bashkirian (Chokerian) to Gzhelian (Stephanian) (Němejc, 1953). However, the species is mainly known from the middle Bashkirian (Langsettian) to lower Moscovian (Bolsovian) (Boureau, 1964). This long stratigraphic range could be explained by the fact that this kind of stem in itself probably includes several natural species. The species is in need of detail taxonomic revision.

Species Calamites (Crucicalamites) cruciatus Sternberg 1825 (Plate VII, Fig. 1)

Only one specimen is observed from the collection from this locality in the Museo Civico di Storia Naturale. The species is easily distinguished from other calamitalean species because the carinal canals converge slightly on the branch scars. Branch scars are varied from $5 \mathrm{~mm}$ to $10 \mathrm{~mm}$. The internodes are wider than high. The internodes are $20 \mathrm{~mm}$ high and $60 \mathrm{~mm}$ wide. The carinal canals are straight except near the large branch scares (nodes). Both kinds of branch scars are placed in nodes, from 3 to 4 in number. Leaf scars are not present.

Remarks: This species has a stratigraphic range from middle Bashkirian (Langsettian) to Gzhelian (Stephanian), however it mainly occurs in lower Moscovian (Bolsovian) to Kasimovian (Barruelan) floras (Boureau, 1964).

Species Calamites (Stylocalamites) cisti Brongniart 1828 (Plate VII, Fig. 2)

Like Calamites cruciatus, one specimen was recognized from the collection from this locality.

The stem is $40 \mathrm{~mm}$ broad. Internodes are $35 \mathrm{~mm}$ long. Carinal canals are narrow and straight, having elliptical scars in the upper part (in the nodal region). At the bottom of the carinal canals are only a small scar represented by „dots“ (again nodal area). Carinal canals have a character of flattened straight canals that are separated by a narrow groove.

Remarks: This species has a large stratigraphic range from Pennsylvanian to Permian (Němejc, 1953), but is mainly known from the lower Moscovian (Bolsovian) (Němejc, 1953; Boureau, 1964). The long stratigraphic range could be explained by the fact that this kind of stem in itself probably includes several natural species. The species needs detail taxonomic revision.

Species Annularia radiata (Brongniart 1822) Sternberg 1825 (Plate VII, Figs 6, 7)

A few specimens of Annularia radiata were observed in the collection from the studied locality which is housed in the Museo Civico di Storia Naturale (Milan) and also in the Museo Etnografico e Naturalistico Val Sanagra. The ultimate shoot is $1 \mathrm{~mm}$ broad. Three whorls are presented on the specimen. Two adjacent whorls on the ultimate shoot is $12 \mathrm{~mm}$ broad. One whorl has up to 15 leaves. Leaves are laminar, lanceolate, $5 \mathrm{~mm}$ long and $0.8-1 \mathrm{~mm}$ wide (in the middle part of leaf) with more or less sharp tip. The specimen figured on the Plate VII, figure 7 probably represents a juvenile stage of this species. Leaves are still undeveloped (Figure 6).

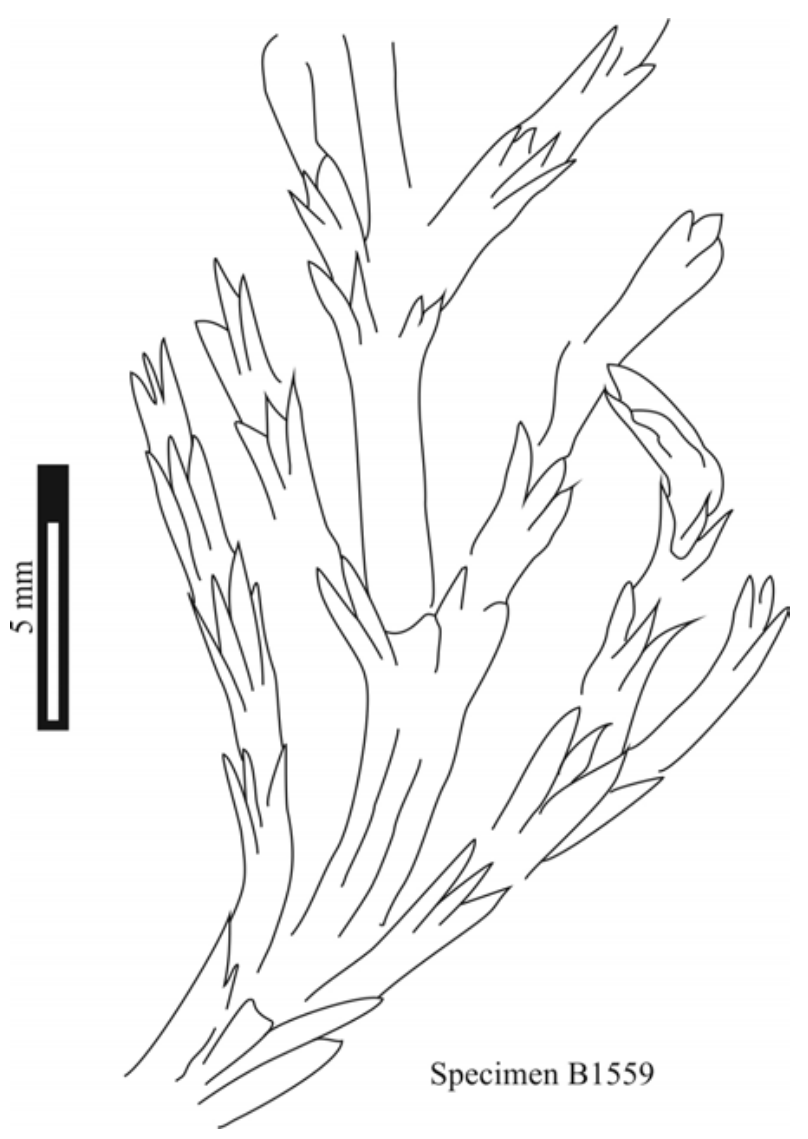

Figure 6. Probably a juvenile stage of Annularia radiata with undeveloped leaves; camera lucida from specimen B1559. 
Remarks: This species occurs from the Serpukhovian to Gzhelian, nevertheless the most abundace of the species is from the middle Baskhirian (Langsettian) to lower Moscovian (Bolsovian) (Boureau, 1964; Němejc, 1953).

Species Asterophyllites longifolius (Sternberg 1825) Brongniart 1828 (Plate VII, Fig. 3)

One specimen shows interesting calamitalean leaves having diagnostic features of Asterophyllites longifolius. It represents part of leafy branch, more than $60 \mathrm{~mm}$ long. The shoot axis is $2-3 \mathrm{~mm}$ broad, and is slightly thickened at the nodes. The distance between the nodes is $15 \mathrm{~mm}$. Characteristic, very long linear leaves are $35-40 \mathrm{~mm}$ long and $0.8-1 \mathrm{~mm}$ wide with a sharp tip. The leaves are fused together in a small area (ca. $0.2 \mathrm{~mm}$ ) near their attachment point to the nodes. More than 11 leaves are attached to each node.

Remarks: This species has a wide stratigraphic range from Moscovian to the Permian (Boureau, 1964; Němejc, 1953).

Species Calamostachys cf. tuberculata (Sternberg 1825) Jongmans 1915 (Plate VII, Figs 4, 5)

The studied material included several specimens of calamitalean cones assigned to the same species. The cones are more than $50 \mathrm{~mm}$ long and 5 $8 \mathrm{~mm}$ wide (Plate VII Fig. 4). Internodes are 3 $4 \mathrm{~mm}$ long with the axis $2 \mathrm{~mm}$ broad. Sterile bracts are lanceolate, $5-7 \mathrm{~mm}$ long. Cones are really poorly preserved which makes it impossible to distinguish sterile and fertile parts, or to determine the character of the sporangia.

Remarks: This species is mainly known from the Moscovian (Bolsovian - Asturian), although it also occurs in the Kasimovian and Gzhelian stages, as well as in Permian deposits (Boureau, 1964; Němejc, 1953).

Species Asterophyllites equisetiformis (Schlotheim 1820) Brongniart 1828 (Plate VII, Fig. 8)

The collection contains only a single, poorly preserved specimen of this species. The leaves are typically short, acicular and arranged in whorls. The sample could not be photographically documented.

Remakrs: The species is not stratigraphically significant.

\section{Division Pteridopsida}

\section{Order Marattiales}

\section{Family Asterothecaceae}

Subfamily Miltonoideae

Species Lobatopteris cf. simonii Zeiller 1888 (Plate VIII)

Several specimens of Pecopteris cf. simonii were identified within the material from the study locality. Nevertheless, it is not an abundant species. The specimens represent fragments of sterile penultimate pinnae, most of them with incomplete ultimate pinnae (Plate VIII, Figs 1, 5). The penultimate rachises are not visible. Ultimate rachises are $2.5 \mathrm{~mm}$ broad and form an angle of $50^{\circ}$ with the penultimate rachis. The ultimate pinnae are more than $40 \mathrm{~mm}$ long and $7 \mathrm{~mm}$ wide (Plate VIII, Figs 3,4). Due to poor preservation of specimens, it is impossible to describe any ornamentation on the rachises. Pinnules are attached to the ultimate rachis at between $90^{\circ}$ and $45^{\circ}$. Pinnules are $3 \mathrm{~mm}$ long and $2.5 \mathrm{~mm}$ wide. Two adjacent leaves touch along about half the pinnule length. Their margins converge quickly to their end, which is arched. The midrib is strong, up to about $1 / 3-1 / 2$ the length of the pinnule, slightly curved at the base. Lateral veins dichotomize once or twice, or are rarely simple (Figure 7). The apical pinnule of the ultimate pinna has a triangular shape with rounded apex (Plate VIII, Fig. 2).

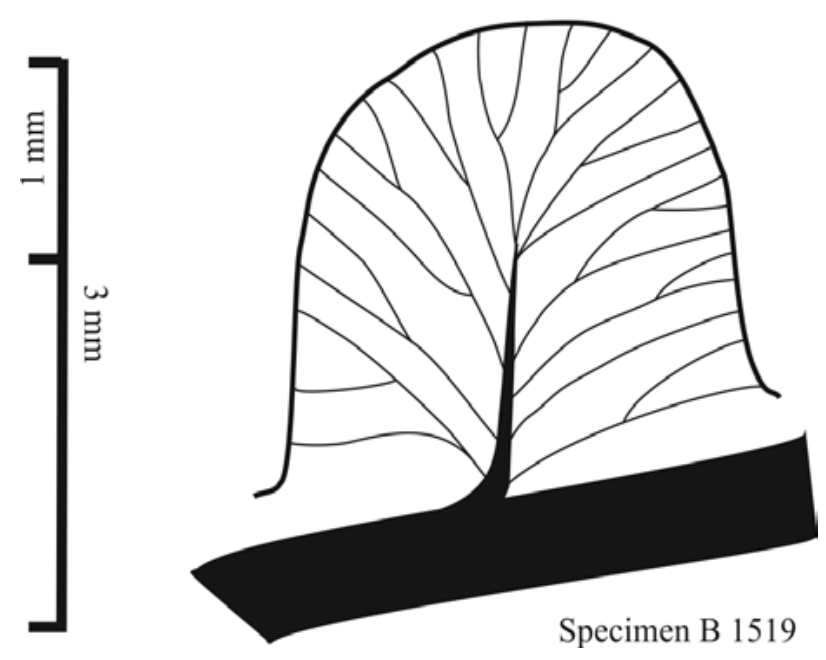

Figure 7. Venation diagram from Lobatopteris icf. simonii with margins converge quickly to their end, which is arched; camera lucida from specimen B1519. 
Folia vol. 46, No. 1-2, 2012

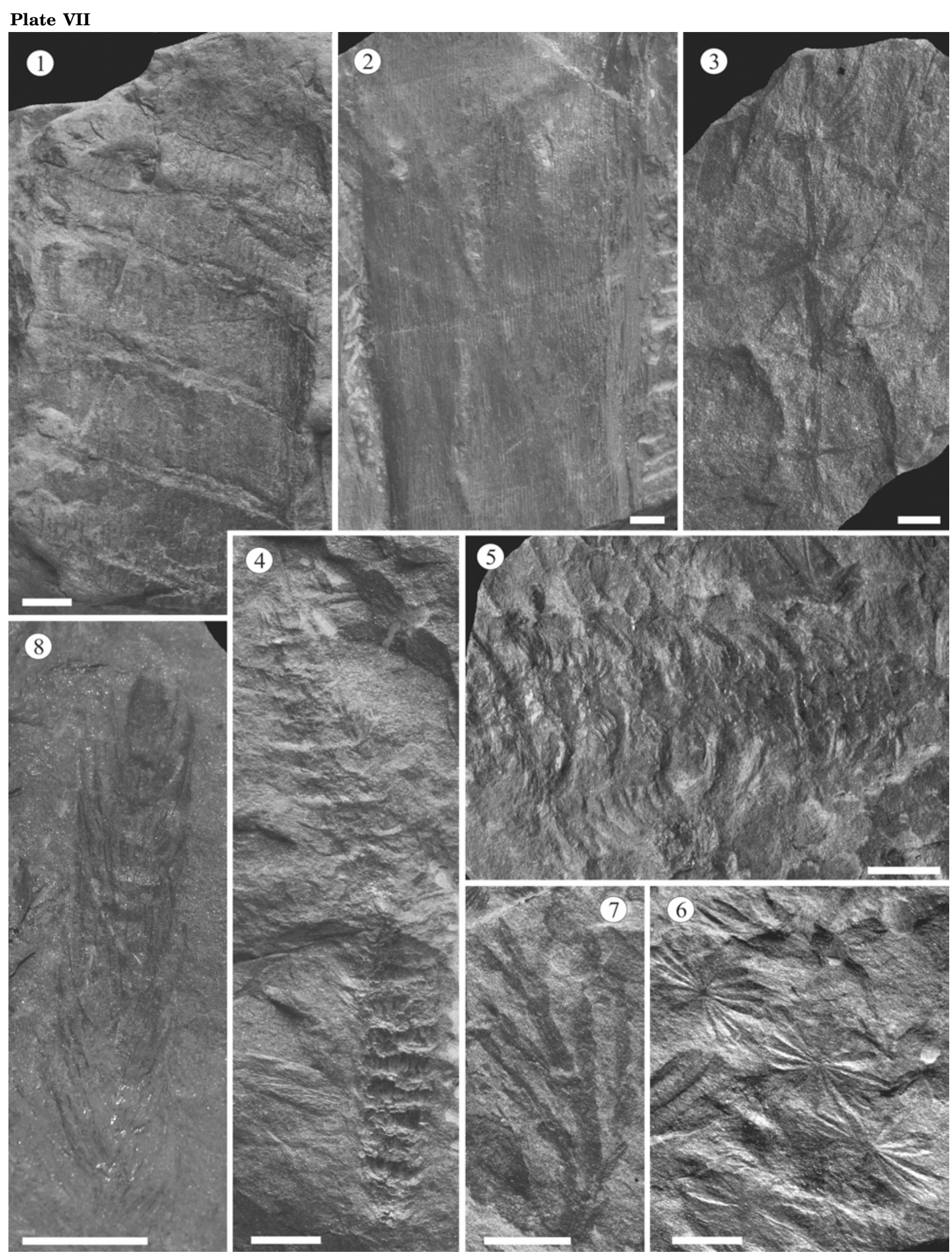


Remarks: These specimens can be compared with the specimen published by Dalinval (1960, plate 56, fig. 1), which also has a strong ultimate rachis, small pinnules and similar venation pattern. Dalinval (1960) mentioned that pinnules of his specimen (Pecopteris cf. simonii) are attached perpendicular to the ultimate rachis, while the pinnules of studied species often form an angle of $45^{\circ}$ with the ultimate rachis. However, fossil remains from Val Sanagra locality are really very poorly preserved and partly tectonically deformed, and so it is impossible to use the angle of attachment of the pinnules as a reliable taxonomical character.

Pecopteris (Lobatopteris) simonii occurs in uppermost Bashkirian (Duckmantian) to middle Moscovian (Bolsovian, Asturian?) strata (Dalinval, 1960).

Species Lobatopteris miltonii (Artis 1825) Wagner 1958 (Plate IX, Figs 1, 3, 4)

Several specimens from Val Sanagra locality have been attributed to this species.

Specimens show sterile fragments of separated ultimate pinnae (Plate IX, Figs 1, 3, 4). Ultimate rachises are $0.8 \mathrm{~mm}$ broad and probably covered by trichomes. Ultimate pinnae are $15 \mathrm{~mm}$ wide and more than $30 \mathrm{~mm}$ long, parallel-sided for most of their length and have blunt $\left(70-90^{\circ}\right)$ terminals. Pinnules alternate on the ultimate rachis, are pinnatifid, $7-8.4 \mathrm{~mm}$ long and $2-2.4 \mathrm{~mm}$ wide, usually with no more than 5 pairs of lobes along their length (Plate IX, Fig. 4). Venation is not visible because of poor preservation.

Remarks: The studied specimens compare well with the Lobatopteris miltonii holotype described by Pšenička et al. (2009).

Lobatopteris miltonii occurs in middle Bashkirian (Langsetian) to early Moscovian (Bolsovian) strata (Němejc, 1953; Dalinval, 1960).
Species Pecopteris microphylla Corsin 1951 (Plate IX, Fig. 2)

Several species from collections housed in the Museo Civico di Storia Naturale and Museo Etnografico e Naturalistico Val Sanagra belong to this species. The lateral veins once divided, close to the midvein, into two arms which are decurring against each other, straight the pinnule margin with a rounded/triangular tip.

Remarks: Lobatopteris microphylla occurs from Moscovian (Bolsovian) to the lowermost Kasimovian (Corsin, 1951).

\section{Order Zygopteridales}

Family Zygopteridaceae

Species: Corynepteris (Alloiopteris) sp. (Plate IX, Figs 5, 6)

Only two sterile specimens of Corynepteris were discovered in the collections from Val Sanagra locality.

Both specimens show small fragments of penultimate pinnae with three incomplete ultimate pinnae attached (Plate IX, Fig. 5). The penultimate rachis is $2 \mathrm{~mm}$ broad and hirsute. The distance between two adjacent ultimate rachises is $10 \mathrm{~mm}$. Ultimate pinnae are linear, $4-4.5 \mathrm{~mm}$ broad and more than $15 \mathrm{~mm}$ long. The ultimate rachises are $0.6 \mathrm{~mm}$ broad. Although the pinnules are really poorly preserved, it appears that they are free or partly merged, asymmetrical, $2.2 \mathrm{~mm}$ long and $1.1 \mathrm{~mm}$ wide (Plate IX, Fig. 5).

Remarks: The studied specimens show a similarity with Corynepteris sternbergii Ettingshausen sensu Zeiller described from Újezd u Svatého Kř́že, Radnice Basin, Czech Republic (Pšenička and Opluštil, 2011). However, a detail comparison cannot be done because of the absence of diagnostic features.

\section{Plate VII}

1) Calamites (Crucicalamites) cruciatus; Museo Civico di Storia Naturale (Milan); specimen B1960; scale bar $10 \mathrm{~mm}$; 2) Calamites (Stylocalamites) cisti; Museo Civico di Storia Naturale (Milan); specimen B1886; scale bar 5 mm; 3) Asterophyllites longifolius; Museo Civico di Storia Naturale (Milan); specimen B1761; scale bar $5 \mathrm{~mm}$; 4) Calamostachys tuberculata; Museo Civico di Storia Naturale (Milan); specimen B1902; scale bar $5 \mathrm{~mm}$; 5) Calamostachys tuberculata; Museo Civico di Storia Naturale (Milan); specimen B1887; scale bar $5 \mathrm{~mm}$; 6) Annularia radiata; Museo Civico di Storia Naturale (Milan); specimen B1888; scale bar $5 \mathrm{~mm}$; 7) the juvenile stage of Annularia radiata; specimen B1559; scale bar $5 \mathrm{~mm}$; 8) Asterophyllites equisetiformis; apical part; the Museo Etnografico e Naturalistico Val Sanagra; scale bar $10 \mathrm{~mm}$. 


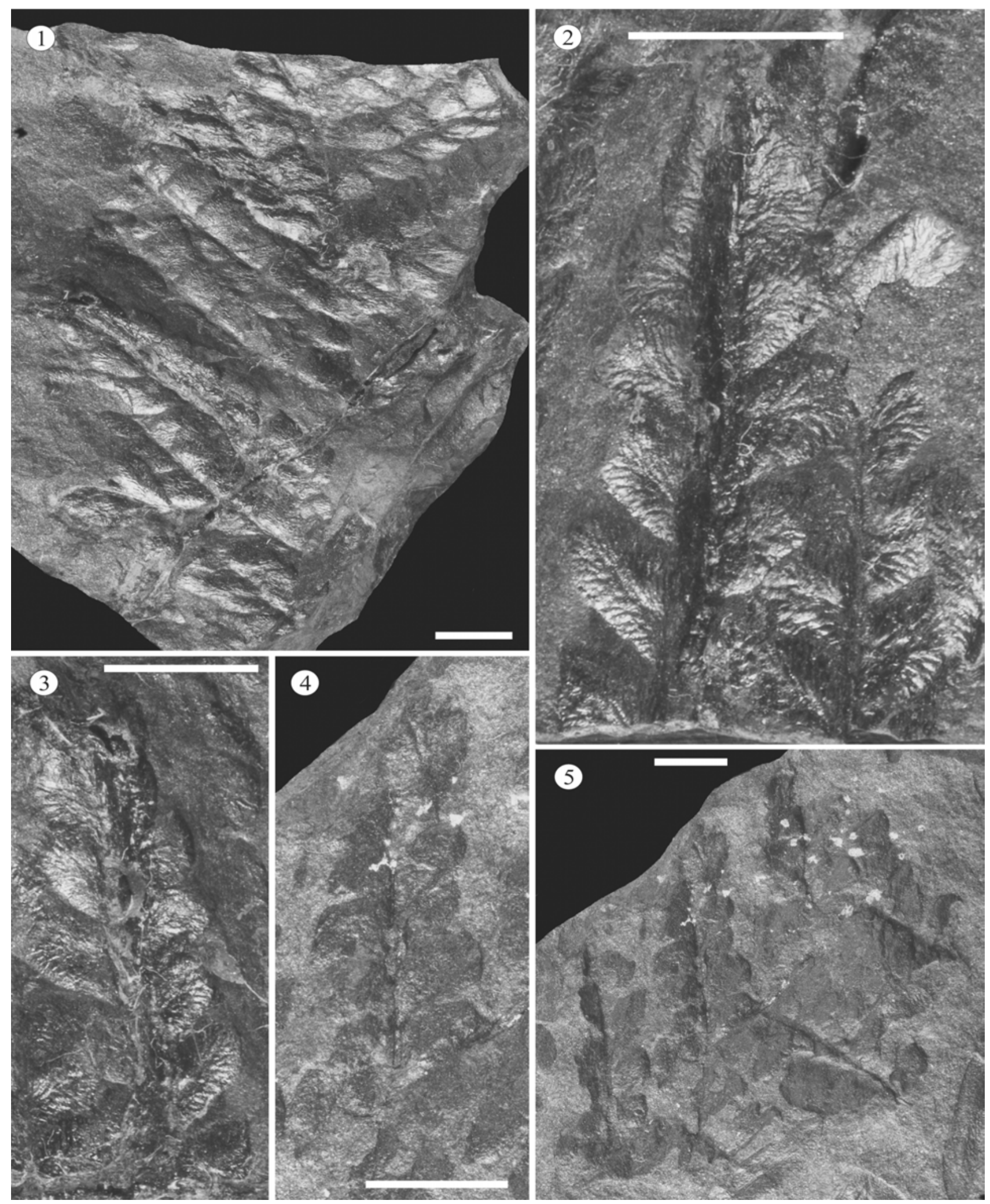

Plate VIII - Lobatopteris cf. simoni; Museo Civico di Storia Naturale (Milan).

1) specimen B1519; scale bar $5 \mathrm{~mm}$; 2) specimen B1519; scale bar $5 \mathrm{~mm}$; 3) specimen B1519; scale bar 5 mm; 4) specimen B1546; scale bar $5 \mathrm{~mm}$; 5) specimen B1546; scale bar $5 \mathrm{~mm}$. 
Corynepteris sternbergii ranges stratigraphically from the middle Bashkirian (Yeadonian) to middle Moscovian (Asturian), but is most common in strata of the early Moscovian (Duckmantian, Bolsovian) age (Němejc, 1953; Galtier and Scott, 1979).

\section{Order: Filicales (leptosporangiate ferns)}

\section{Family: Tedeleaceae}

Species: Senftenbergia plumosa (Artis 1825) Stur 1877 (Plate X)

This common Euramerican species occurs abundantly at the studied locality. Nevertheless, all specimens are really poor preserved.

The largest specimen B1634 (Plate X, Fig. 1) shows part of antepenultimate rachis more than $80 \mathrm{~mm}$ long with $2 \mathrm{~mm}$ thick straight rachis. The penultimate pinnae alternate on the antepenultimate rachis, and are lanceolate, more than $40 \mathrm{~mm}$ long $15-18 \mathrm{~mm}$ wide, with a straight rachis $0.7 \mathrm{~mm}$ wide. The distance between adjacent penultimate pinnae is $17,6 \mathrm{~mm}$. The ultimate pinnae are linear lanceolate, $10 \mathrm{~mm}$ long and $2 \mathrm{~mm}$ wide, slowly tapering toward the acute apex (Plate X, Figs 3,4$)$. The pinnules alternate, are more or less oblique, triangular, elongate, and are attached to the ultimate rachis by the whole base. The pinnules are $1-5 \mathrm{~mm}$ long and $1-3 \mathrm{~mm}$ wide (Plate $\mathrm{X}$, Fig. 2). The midvein extends to the apex. Lateral veins are not visible.

Remarks: The penultimate pinna is too narrow and some pinnules are relatively small (specimen B163) in comparison with measurements of the Senftenbergia plumosa specimens published by Pšenička and Bek (2003). It probably, therefore, represents a part of an immature pinna.

Senftenbergia plumosa stratigraphically ranges from uppermost middle Bashkirian (Yeadonian) (Carboniferous) to Cisuralian (Permian) strata (Bek and Pšenička, 2001).

\section{Division: Gymnospermopsida}

\section{Order: Lyginopteridales}

\section{Family: Insertae sedis}

Species: Sphenopteris sp. (Plate XI, Figs 1, 2)

Specimen B1671 is a fragment of sphenopterid foliage, $20 \mathrm{~mm}$ long, with a rachis with several incomplete and one complete sphenopterid pinnules
(Plate XI, Figs 1, 2). The rachis is $1 \mathrm{~mm}$ broad and slightly curved. The complete pinnule is lobate, $6 \mathrm{~mm}$ long and $4 \mathrm{~mm}$ wide with a serrate/dentate margin (Figure 8). The pinnule base is slightly constricted. The distance between adjacent pinnules is $5 \mathrm{~mm}$. The midvein is strong and slightly S-curved. Lateral veins bifurcate several times.

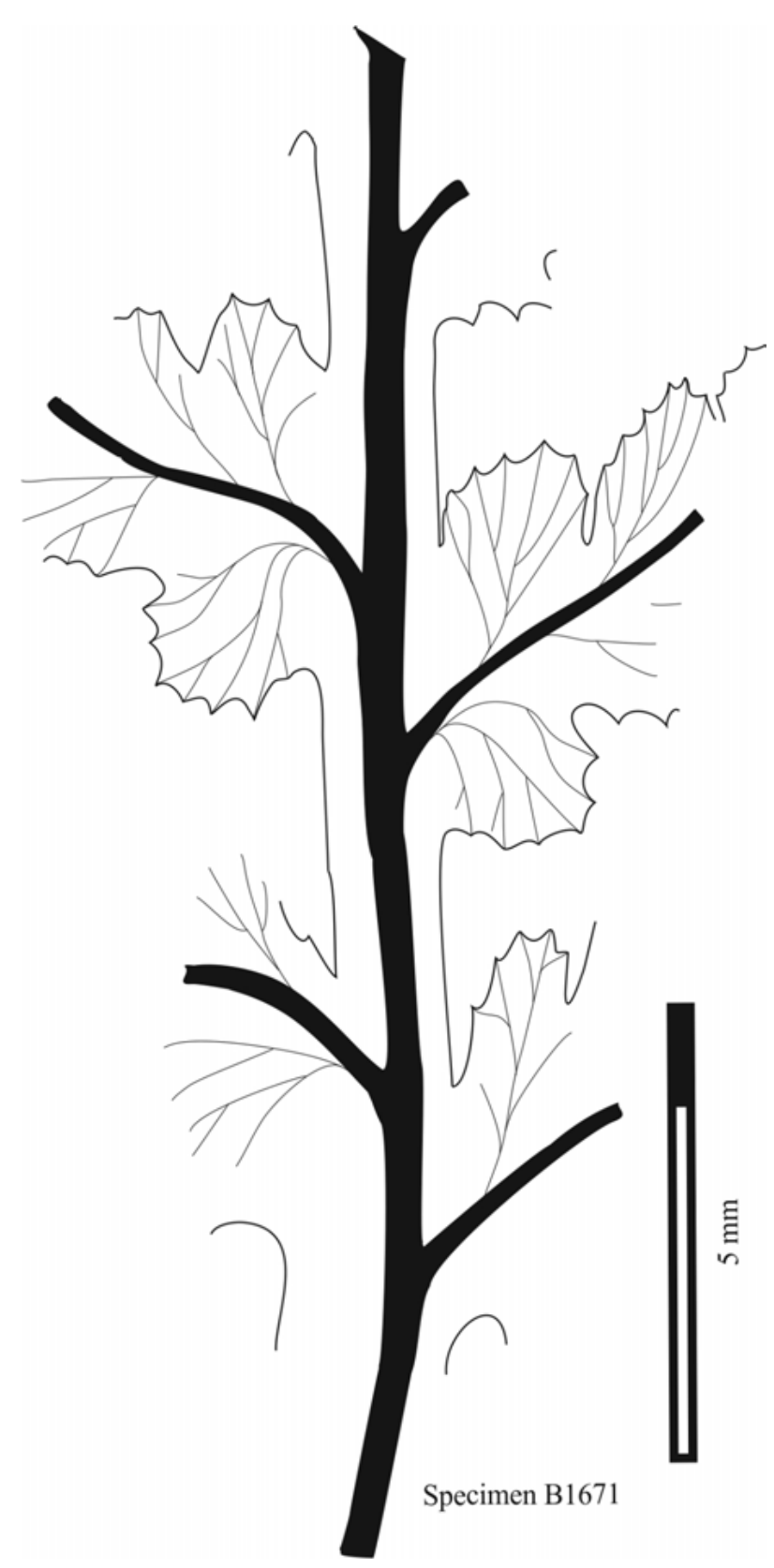

Figure 8. Venation of pinnules of Sphenopteris sp. Pinnules has dentate margin; camera lucida from specimen B1671. 

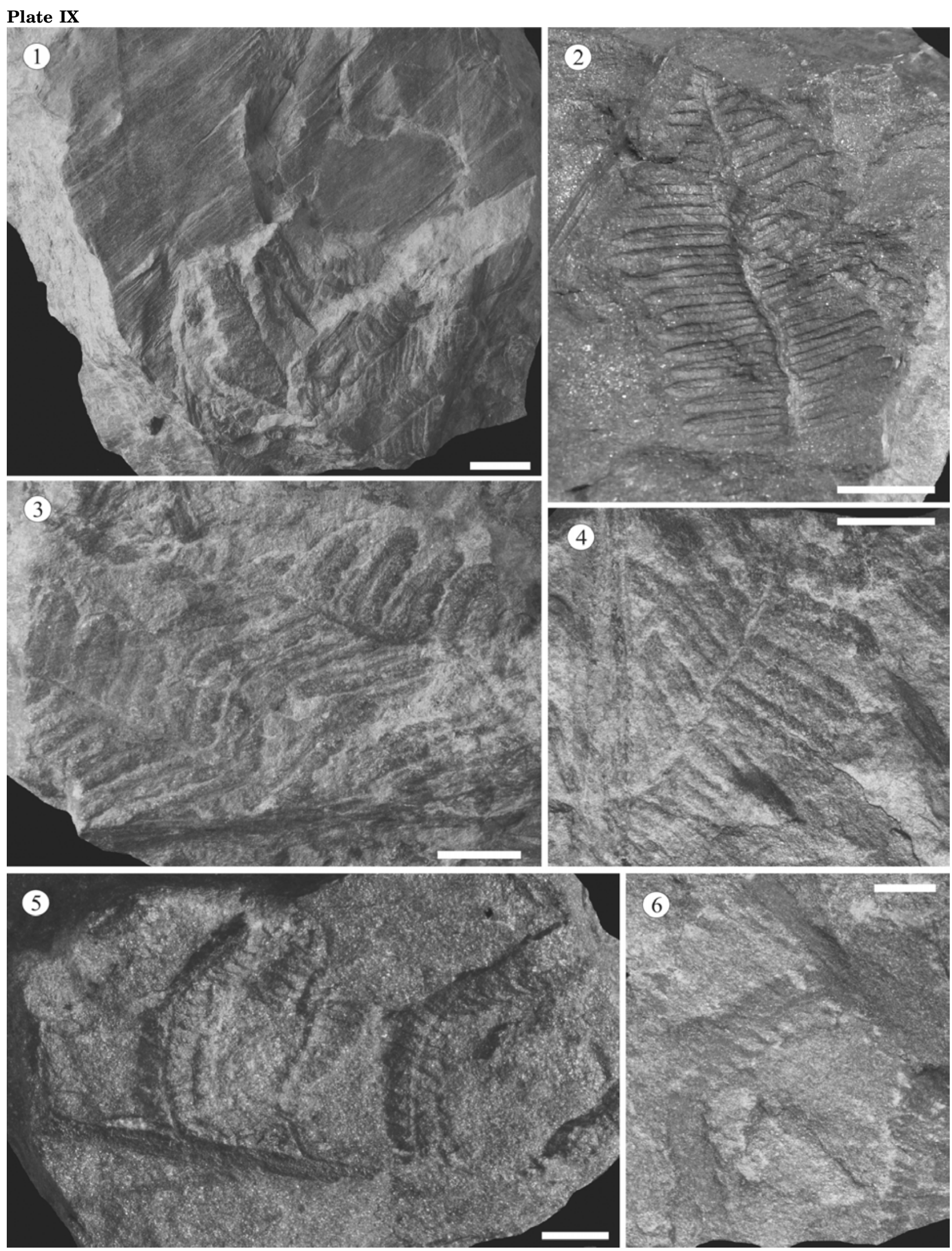
Remarks: The species could be compared with Sphenopteris andraeana Roehl which was described from the middle Moscovian (Bolsovian) of the Saar Basin. Pinnules of both species have sphenopterid pinnules with a serrate/dentate margin. However, $S$. andraeana tends to have more ovate pinnules with a strongly constricted base (Alvaréz-Ramis et al., pl. 1, fig. 1) while the studied Sphenopteris sp. has elongate pinnules with a slightly constricted base (Plate XI, Fig. 1).

The studied specimen could represent a new species but the material is too fragmentary and poorly preserved to be suitable for typifying of a new taxon.

Species: Eusphenopteris cf. neuropteroides (Boulay 1876) Novik 1947 (Plate XI, Figs 3, 4)

This species is represented by only one specimen (B 1893) which shows part of a penultimate pinna with several incomplete ultimate pinnae (Plate XI, Fig. 4). The penultimate rachis is $0.8 \mathrm{~mm}$ broad, bearing alternating ultimate pinnae. The distance between adjacent ultimate pinnae is $6.8 \mathrm{~mm}$. The ultimate rachis is $0.5 \mathrm{~mm}$ broad and makes an angle of $55^{\circ}$ with the penultimate rachis. The ultimate pinnae are more than $25 \mathrm{~mm}$ long and $13 \mathrm{~mm}$ wide (Plate XI, Figs 3, 4). Eusphenopterid pinnules (Figure 9) alternate on the ultimate rachis (Plate XI, Fig. 3), spaced as a distance of $3.7 \mathrm{~mm}$. Pinnules are lobate (4-5 lobes), 5.7 - $8.2 \mathrm{~mm}$ long and 3.5 - $4 \mathrm{~mm}$ wide, slightly elongated, and make an angle of $55^{\circ}$ with the ultimate rachis. The pinnule base is strongly constricted. The tip of the pinnules is more or less triangular or rounded (Plate XI, Figs 3, 4). Venation is not well preserved but a marked midvein is present.

Remarks: The studied specimen corresponds to Eusphenopteris neuropteroides as described by Boulay (1876) and van Ameron (1975). This is not the same as the species that most authors (e.g. Kidston) have tended to name as $E$. neuropteroides. Small differences can be observed in the tip of pinnules. Our studied species has more triangular

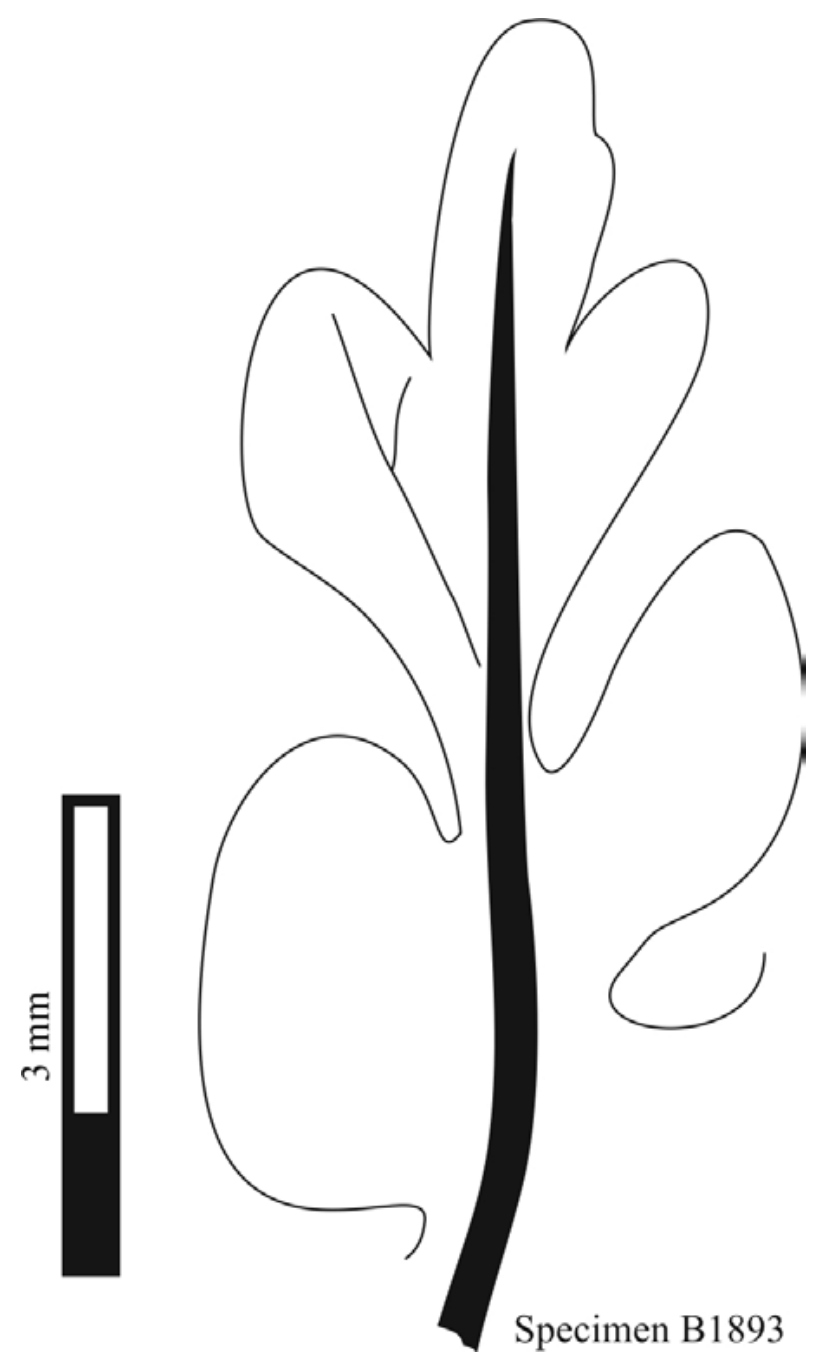

Figure 9. The pinnule shape of Eusphenopteris cf. neuropteroides; camera lucida from specimen B1893.

apical part of pinnules while pinnules in Eusphenopteris neuropteroides have more rounded apical part. Venation pattern cannot be compared because of poor preservation of the studied specimen.

Eusphenopteris neuropteroides stratigraphically ranges from the middle Bashkirian (Langsettian) to middle Moscovian (Bolsovian) (Ameron, 1975).

\section{Plate IX}

1) Lobatopteris miltoni; Museo Civico di Storia Naturale (Milan); specimen B1894; scale bar $10 \mathrm{~mm}$; 2) Pecopteris microphylla; the Museo Etnografico e Naturalistico Val Sanagra; scale bar $10 \mathrm{~mm}$; 3) Lobatopteris miltoni; Museo Civico di Storia Naturale (Milan); specimen B1894; scale bar $5 \mathrm{~mm}$; 4) Lobatopteris miltoni; Museo Civico di Storia Naturale (Milan); specimen B1894; scale bar $5 \mathrm{~mm}$; 5) Corynepteris sp.; Museo Civico di Storia Naturale (Milan); specimen B1788; scale bar 5 mm; 6) Corynepteris sp.; Museo Civico di Storia Naturale (Milan); specimen B1788; scale bar 5 mm. 

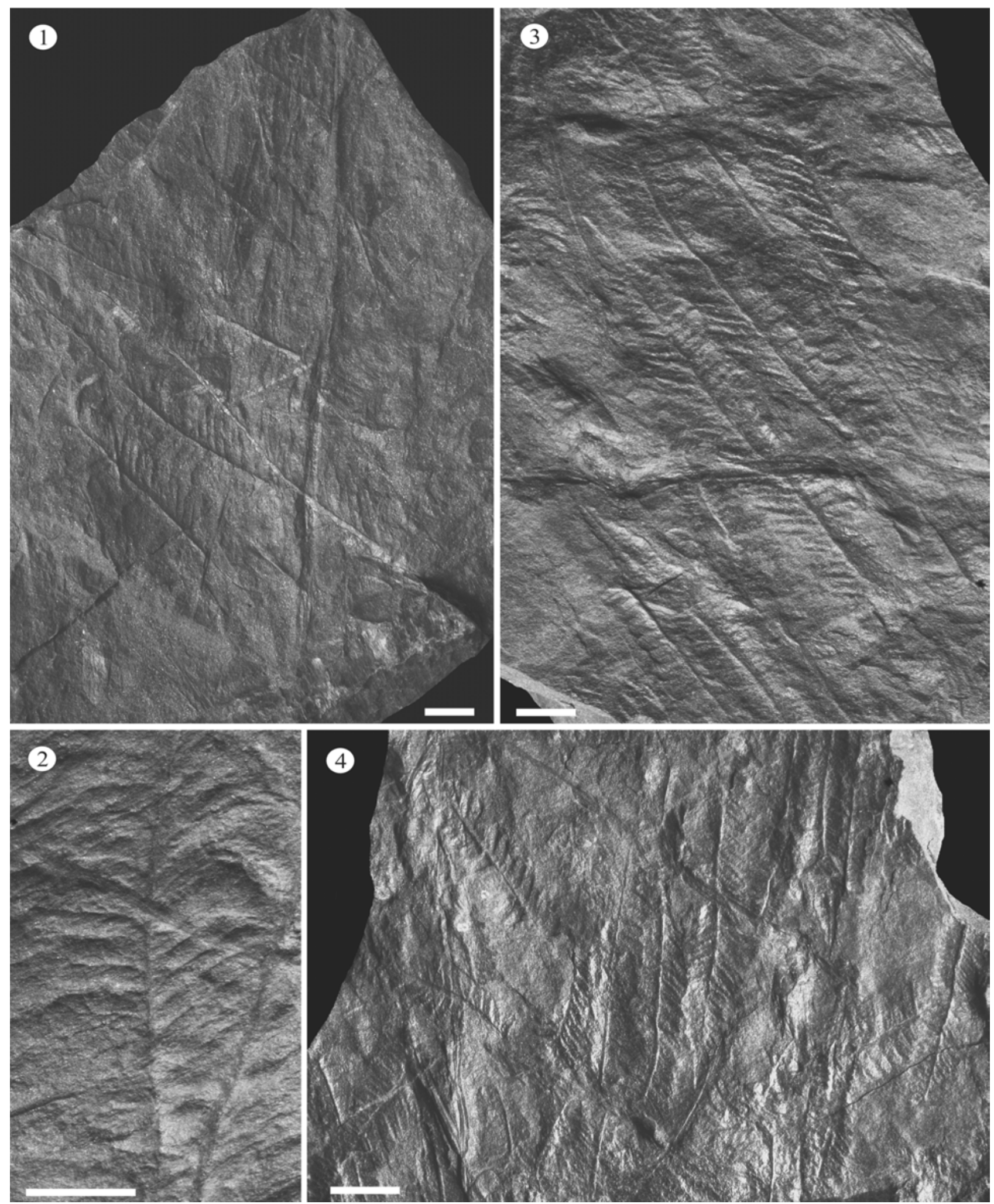

Plate X - Senftenbergia plumosa; Museo Civico di Storia Naturale (Milan).

1) specimen B1634; scale bar $5 \mathrm{~mm}$; 2) specimen B1662; scale bar $5 \mathrm{~mm}$; 3) specimen B1634; scale bar 5 mm; 4) specimen B1662; scale bar $10 \mathrm{~mm}$. 


\section{Order: Callistophytales}

\section{Family: Insertae sedis}

Species: Mariopteris cf. lobatifolia Kidston 1925 (Plate XII, Fig. 1)

Only one specimen (B1904) could be referred to this species. It shows the distal part of a pinna with several ultimate pinnae. The pinna rachis is $2.3 \mathrm{~mm}$ broad. The distance between adjacent ultimate pinnae is $9.3 \mathrm{~mm}$. Ultimate rachises are $0.6 \mathrm{~mm}$ broad and more than $40 \mathrm{~mm}$ long. Pinnules are robust, obtuse, $6-7 \mathrm{~mm}$ long $3-3.5 \mathrm{~mm}$ wide (Plate XII, Fig. 1). Venation is not well preserved but the midvein is well visible.

Remarks: Mariopteris lobatifolia Kidston resembles Mariopteris nervosa (Brongniart) Zeiller, but the pinnules of the latter species are almost invariably united to each other at the base, even on the ultimate pinnae in basal positions in the frond. In Mariopteris nervosa only the basal posterior pinnule has a lobe at the base of their distal margin, while in Mariopteris lobatifolia the succeeding pinnules on both sides of the rachis have a lateral basal lobe. The presence of these lateral lobes also separates M. lobatifolia from Mariopteris sauveuri (Brongniart) Frech. Lateral lobes on Mariopteris sauveuri, when present, are usually feebly developed.

Mariopteris lobatifolia Kidston was described by Kidston (1925) from Great Britain, Yorkshire Coalfield, Barnsley, Peacock Coal of the late Bashkirian (Langsettian) age. It has been also mentioned by Danzé-Corsin (1953) from France, from Pas de Calais, Assise de Bruay, also of Moscovian (Bolsovian) age.

Species: Mariopteris cf. sauveurii (Brongniart, 1833) Frech, 1899 (Plate XII, Figs 2, 3)

This species is represented by two specimens. Specimen B1932 (Plate XII, Fig. 2) shows the uppermost part of a pinna and specimen B1923 (Plate XII, Fig. 3) shows the middle part of an exterior ultimate pinna (2P3ext) of interior pinna (P2 int) (based on terminology of Boersma 1972). The pinna rachis is straight, $0.7 \mathrm{~mm}$ broad. Different pinnules occur in the acroscopic and basiscopic parts (Plate XII, Fig. 3). Acroscopic pinnules are linguaeform, with an obtuse apex, $8 \mathrm{~mm}$ long and $4 \mathrm{~mm}$ wide, and lie at $70^{\circ}$ to the rachis (Plate XII, Fig. 3). Basiscopic pinnules are elongated, 12 -
$15 \mathrm{~mm}$ long and $3-3.7 \mathrm{~mm}$ wide, and lie at $40^{\circ}$ to the rachis (Plate XI, Fig. 3). The midvein is prominent, slightly S-curved in basiscopic pinnules, but the lateral veins are not preserved due to poor preservation.

Remarks: Fragments of Mariopteris sauveurii frond are difficult to distinguish from $M$. nervosa and $M$. lobatifolia. The pinnules of comparable size with Mariopteris nervosa are more elongate and have an obtuse to acute apex, while the apices in Mariopteris sauveurii are rounded. Mariopteris lobatifolia hardly shows fusion of the pinnules, even in small fronds, whereas pinnule fusion is a characteristic for $M$. sauveurii (Boersma, 1972). Mariopteris sauveuri has a very wide geographic distribution e.g. Great Britain, Belgium, France, Germany, Algeria and Turkey (Jongmans and Dijkstra, 1960). It starts in the Duckmantian, occurs most commonly in the Bolsovian, and disappears in the Asturian.

Species: Karinopteris dernoncourti (Zeiller 1886) Boersma 1972 (Plate XII, Figs 4-6)

This species is represented by several small fragments of ultimate pinna at the studied locality. Their rachises are $1.2 \mathrm{~mm}$ broad. Sphenopterid lobate pinnules are $5-11 \mathrm{~mm}$ long and $4.3-5.5$ $\mathrm{mm}$ wide, with a slightly constricted base (Plate XI, Figs 4-6). Pinnules make an angle of $65^{\circ}$ with the rachis. The distance between adjacent pinnules is $6 \mathrm{~mm}$. The midvein is prominent and slightly S-curved (Plate XI, Fig. 4). Lateral veins are not preserved.

Remarks: Kariopteris dernoncourtii looks like $K$. acuta with rounded pinnule apices and therefore determination of "intermediate" pinnules can be problematical. The pinnules of $K$. dernoncourtii are more "sphenopteroid" and more divided than in $K$. acuta. The prominent proximal basal lobes are an important diagnostic feature of Karinopteris dernoncourtii. The pinnule margin can be slightly undulated (Josten, 1991).

Boersma (1972) erected the new genus Karinopteris to accommodate "quadripinnate" forms of Mariopteris. Not all researchers accepted this transfer; e.g. Josten (1991) used the traditional name Mariopteris for this species. The species has got a wide geographical and stratigraphical distribution. It occurs usually in the Langsettian and Duckmantian (Great Britain, Netherlands, Bel- 
Folia vol. 46, No. 1-2, 2012

\section{Plate XI}
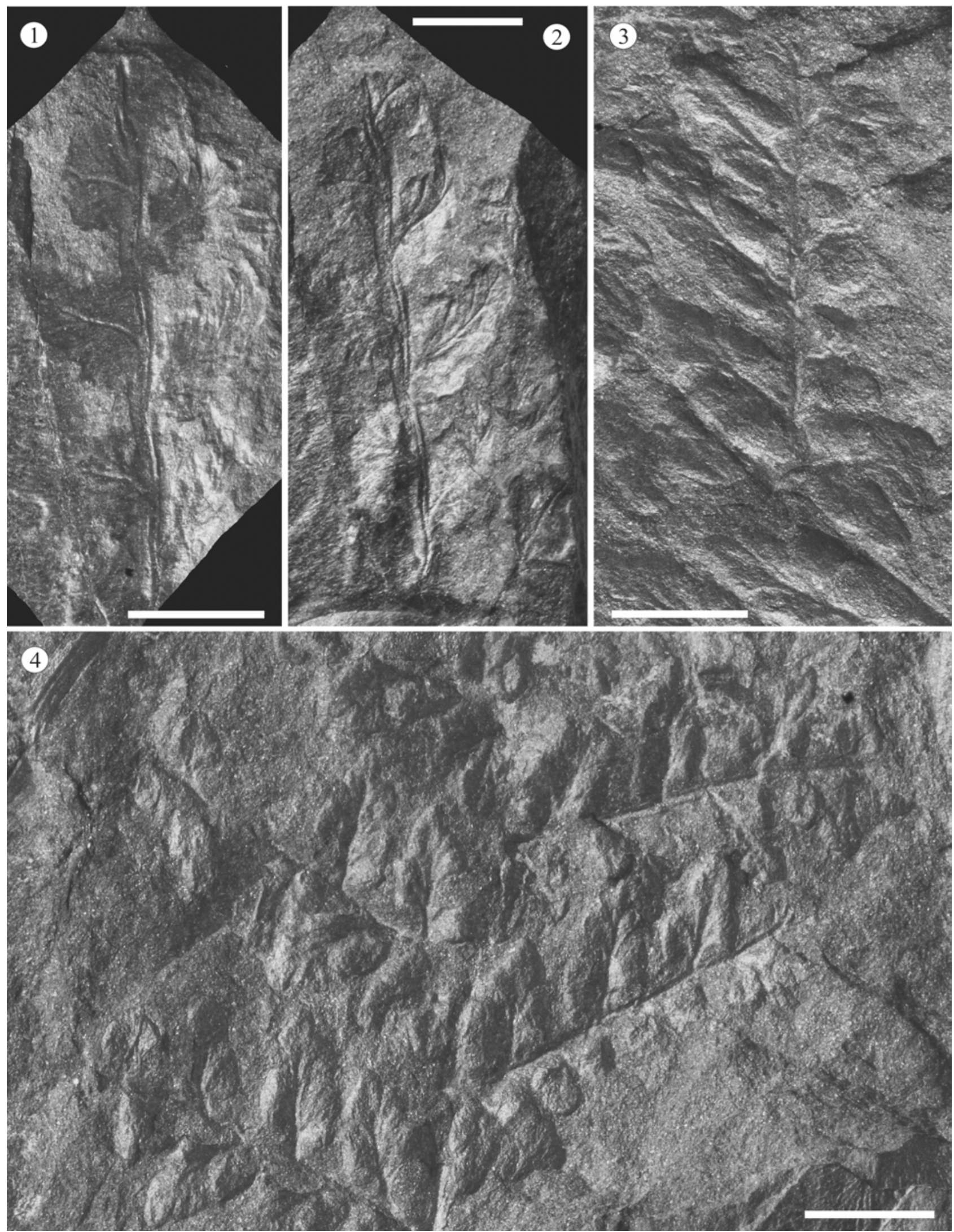
gium, France, Germany, Russia and Turkey) (Jongmans and Dijkstra, 1960). It has been found also in the Namurian - Yeadonian in Poland and Yeadonian and Kindercontian in the Czech Republic (Upper Silesian Basin) Purkyňová (1976).

\section{Order: Medullosales}

\section{Family: Insertae sedis}

Species: Alethopteris sp. [? cf. grandinii (Brongniart, 1828) Goeppert, 1836] (Plate XIII, Figs 1, 5, 7)

Specimen B1894 represents an upper part of a pinna with apical long pinnules with more or less straight (Plate XIII, Fig. 5) or lobate margins (Plate XIII, Fig. 5). Pinnules are more than $10 \mathrm{~mm}$ long and $4 \mathrm{~mm}$ wide, and the rachis is $1 \mathrm{~mm}$ broad. Specimen B1902 (Plate XIII, Fig. 1) shows the apical part of an ultimate pinna with apical pinnules $3-4 \mathrm{~mm}$ long and $1.8-2 \mathrm{~mm}$ wide and larger pinnules $8 \mathrm{~mm}$ long and $3 \mathrm{~mm}$ wide (Figure 10). Pinnules are linguaeform. The rachis is $1 \mathrm{~mm}$ broad. Pinnules lie at $45^{\circ}$ to the rachis. The midvein is marked and extends for $2 / 3$ of the pinnule length. Lateral veins are not visible.

Remarks: Identifying the Alethopteris species from Val Sanagra is difficult because the venation, which is a critical feature in determining Alethopteris species, is not preserved. We considered that specimen B1902 (Plate XIII, Fig. 1) could belong either to Alethopteris grandinioides Kessler or Alethopteris grandinii Brongniart (Goeppert) based on their relatively small pinnules. Alethopteris grandinioides Kessler, 1916 is poorly documented, the original illustration baing a retouched photograph and its holotype has been lost. Therefore Wagner (1968) selected a neotype but, according to Zodrow and Cleal (1988), this did not reflect the original characteristics of Kessler's (1916) specimen. Zodrow and Cleal (1998) solved this problem by erecting a new species, Alethopteris pseudograndinioides Zodrow and Cleal, to replace A. grandinioides Wagner (non Kessler).

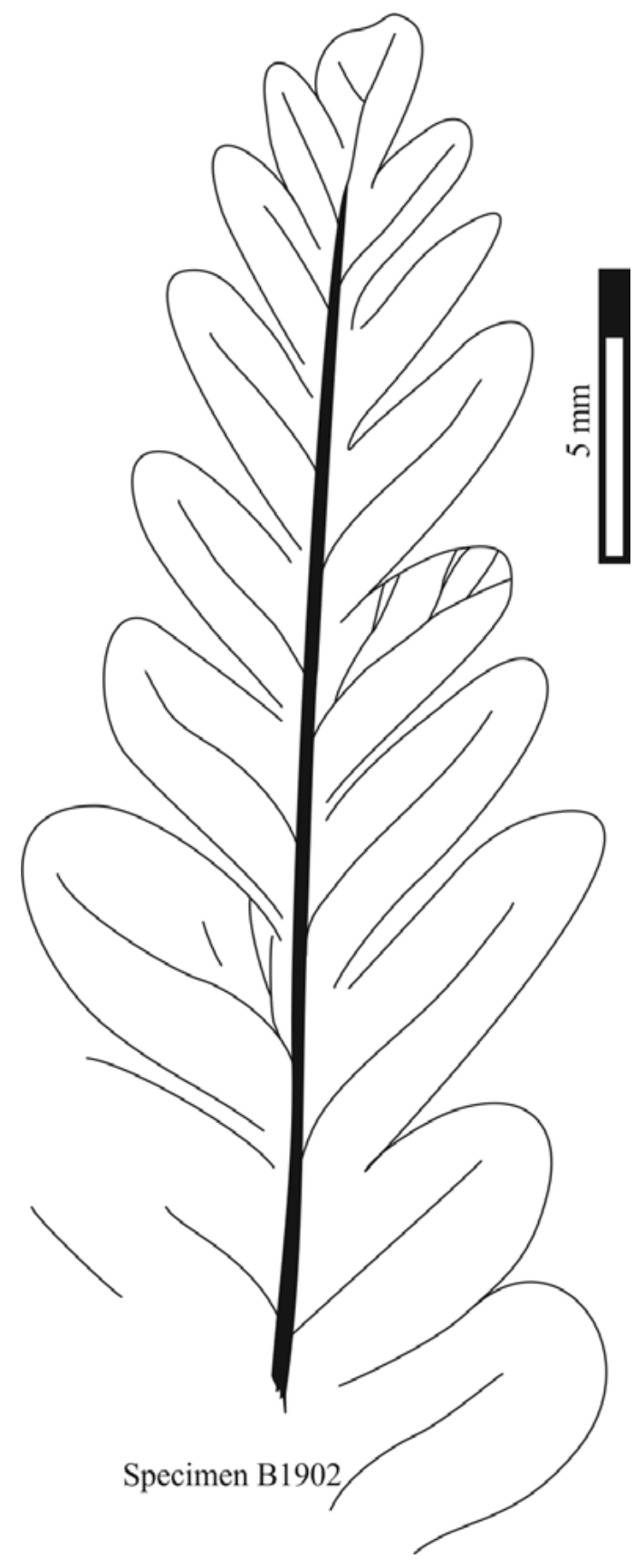

Figure 10. Ultimate pinna of Alethopteris sp.(cf. grandinii); camera lucida from specimen B1902.

\section{Plate XI}

1) Sphenopteris sp.; Museo Civico di Storia Naturale (Milan); specimen B1671; scale bar 5 mm; 2) Sphenopteris sp.; Museo Civico di Storia Naturale (Milan); specimen B1671; scale bar $5 \mathrm{~mm}$; 3) Eusphenopteris cf. neuropteroides; Museo Civico di Storia Naturale (Milan); specimen B1893; scale bar; 4) Eusphenopteris cf. neuropteroides; Museo Civico di Storia Naturale (Milan); specimen B1893; scale bar $5 \mathrm{~mm}$. 
Folia vol. 46, No. 1-2, 2012
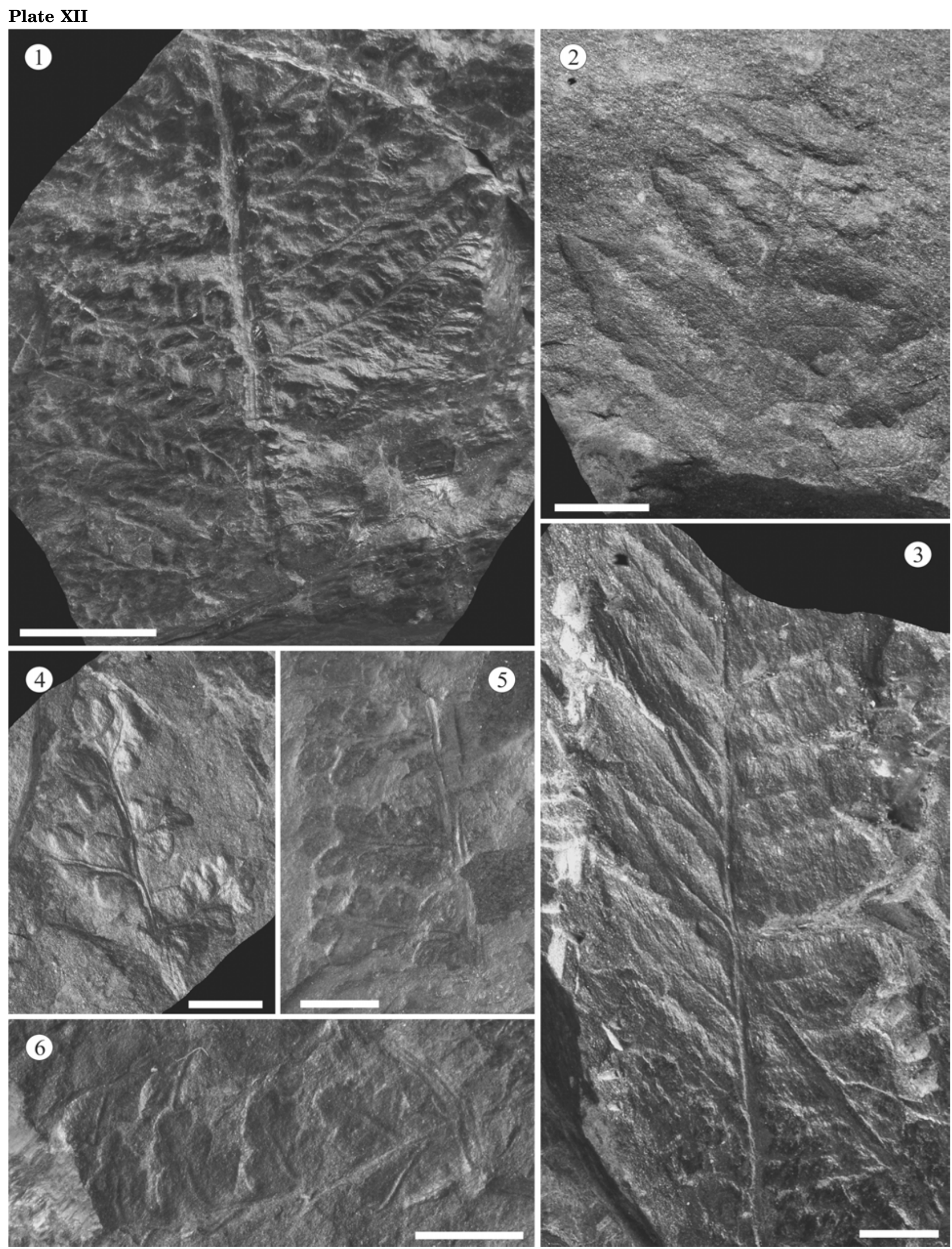
Alethopteris grandinii, A. grandinioides and A. pseudograndinioides have holotypes of Westphalian D (Asturian) age, but they can also occur stratigraphically lower, in the Bolsovian.

The reason, why we decided for Alethopteris grandinii is in its pinnule shape. Alethopteris grandinii has gibbous pinnules that are also on sample B1902. The pinnules near the pinna apex become shorter and more slender, and the terminal is also short and small in both $A$. grandinii and sample B1902 (not preserved in full length (Pl. XIII, Fig. 1). A. grandinioides Kessler has usually "flat" pinnules, slightly prominent midvein, and relatively wider and longer terminal pinnules. On the other hand, sample B1902 (Fig. 10) has rounded pinnule apices that are rather more characteristic for Alethopteris pseudograndinioides Zodrow and Cleal (A. grandinioides Wagner) than for Alethopteris grandinii, the latter having rather bluntly acuminate to rounded apices. According to these notes, it is very difficult to decide to which species the specimens on Pl. XIII belong. We identified them as Alethopteris sp. with a little probability, that the specimen on Pl. XIII, Fig. 1 could belong to Alethopteris grandinii.

Species: Alepthopteris sp.A (Plate XIII, Figs 2, 6) Specimen B1788 shows several very poorly preserved fragments of pinnae. Pinnules are small, elongated, linguaeform, subtriangular, $5 \mathrm{~mm}$ long and $1 \mathrm{~mm}$ wide and united in lower part. The rachis is $0.5 \mathrm{~mm}$ broad. The midvein is prominent but the lateral veins are not visible.

Remarks: It is difficult to make a comparison, when venation is not preserved. Only one species has such narrow pinnules (1 mm wide) - Alethopteris decurrens (Artis) Frech. However, it tends to have much longer pinnules.

Species: Alepthopteris sp.B (Plate XIII, Figs 3, 8) Specimens B1771 (Plate XIII, Fig. 3) and part of specimen B1902 (Plate XIII, Fig. 8) show a small fragment of what is probably an alethopterid pinna.
Pinnules are elongated, linguaeform, $8 \mathrm{~mm}$ long and $2 \mathrm{~mm}$ wide; adjacent pinnules are united in their basal parts. The rachis is $0.7 \mathrm{~mm}$ broad. The midvein is prominent for $3 / 5$ of the pinnule length. Remarks: As with the previous species, the venation is very poorly preserved and pinnule apices are not preserved, and so any comparison is difficult. The pinnules are a little longer and wider than in the previouslyand becauseof its species and with its dimension it could belong to various alethopteroid species.

Species: Neuralethopteris cf larischii (Šusta, 1930) Laveine, 1967. (Plate XIII, Fig. 4)

Several specimens could be assigned to the genus Neuralethopteris, most notably specimen B1893 (Plate XIII, Fig. 4). Pinnules are linguaeform, elongated, $12 \mathrm{~mm}$ long and $2.3 \mathrm{~mm}$ wide, and attached to the rachis by a width of $0.8 \mathrm{~mm}$. The pinnules have a weakly cordate base, are parallelsided in their proximal part, and taper in their distal part to an bluntly acute apex (Figure 11). The midvein lies in a pronounced longitudinal furrow that extends for most of the length of the pinnule. Lateral veins are not visible.

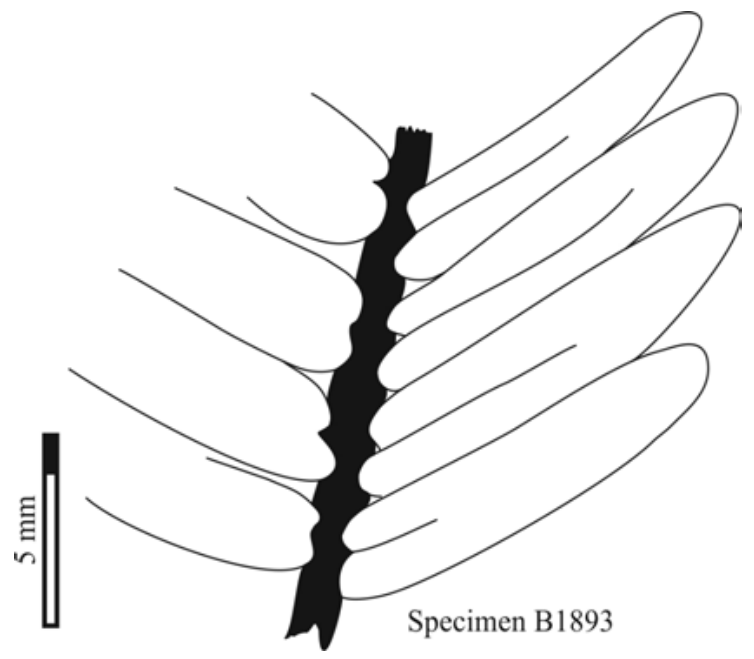

Figure 11. Ultimate rachis with pinnules of Neuralethopteris cf. larischii; camera lucida of the specimen B1893.

\section{Plate XII}

1) Mariopteris cf. lobatifolia; Museo Civico di Storia Naturale (Milan); specimen B1904; scale bar 10 mm; 2) Mariopteris cf. sauveurii; Museo Civico di Storia Naturale (Milan); specimen B1932; scale bar 5 mm; 3) Mariopteris cf. sauveurii; Museo Civico di Storia Naturale (Milan); specimen B1923; scale bar 5 mm; 4) Karinopteris dernoncourti; Museo Civico di Storia Naturale (Milan); specimen B1887; scale bar $5 \mathrm{~mm}$; 5) Karinopteris dernoncourti; Museo Civico di Storia Naturale (Milan); specimen B1897; scale bar $5 \mathrm{~mm}$; 6) Karinopteris dernoncourti; Museo Civico di Storia Naturale (Milan); specimen B1897; scale bar $5 \mathrm{~mm}$. 
Folia vol. 46, No. 1-2, 2012

\section{Plate XIII}
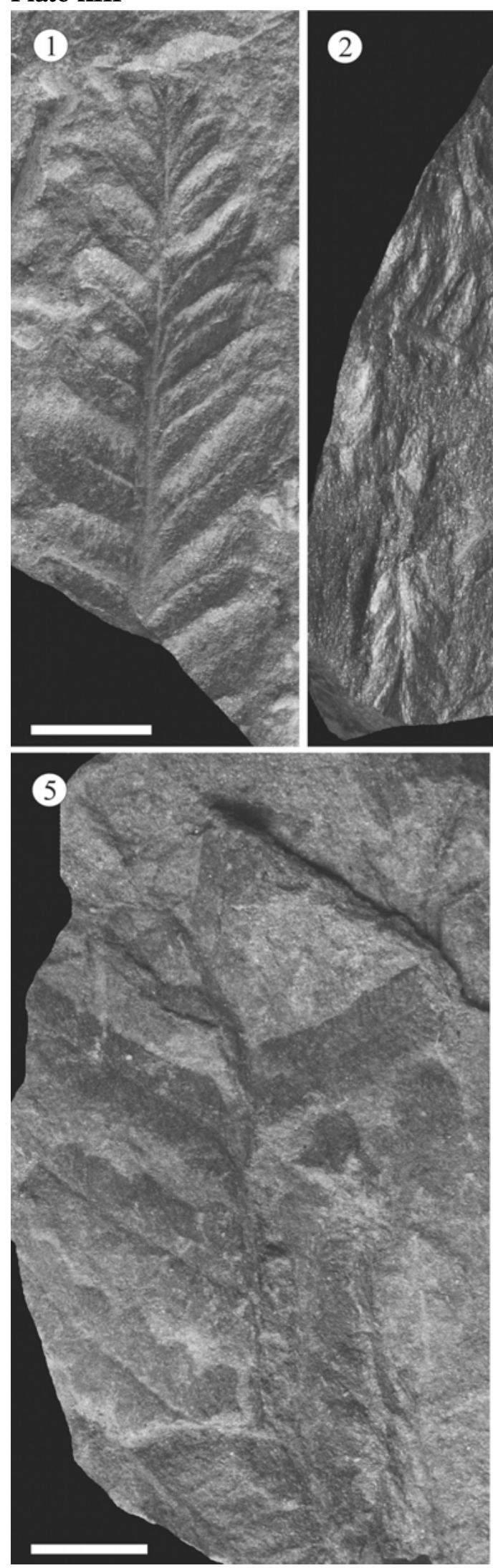

\section{2}
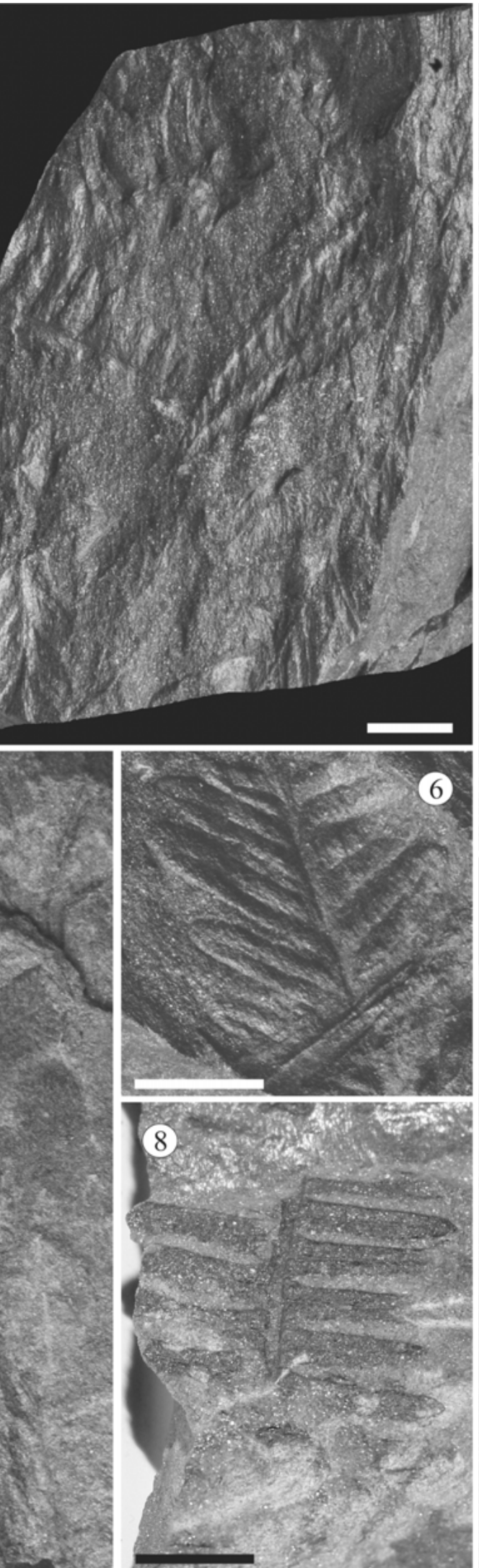
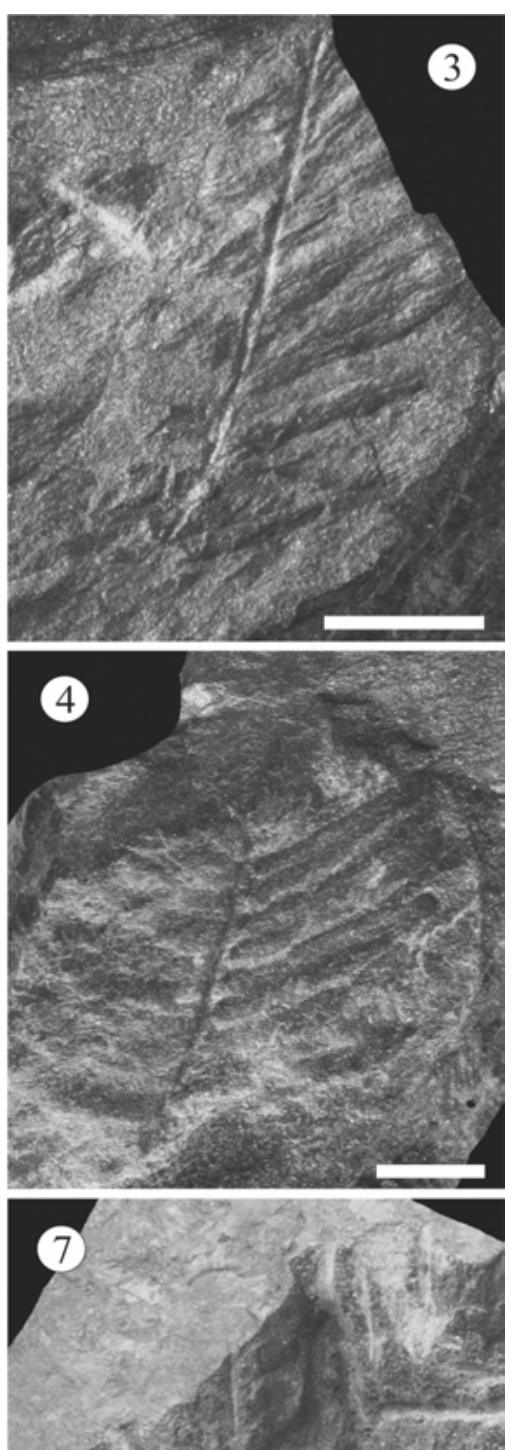

19. $\sqrt{2}$
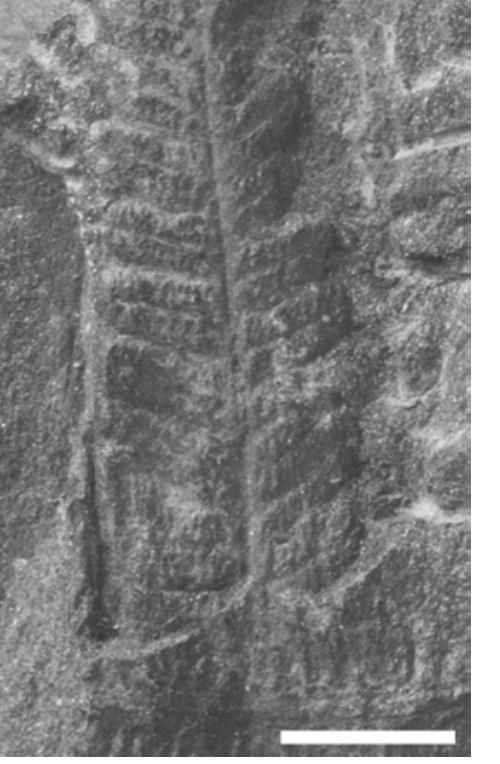
Remarks: Neuralethopteris larishii is very similar to Alethopteris decurrens except that the pinnules have a "neuropteroid" base. It differs from other species of Neuralethopteris Cremer by the form of the pinnules (Josetn, 1983).

The species Neuralethopteris larischii occurs mainly in the Bashkirian Stage, possibly ranging very rarely into the basal Moscovian (Duckmantian) Stage (Tenchov and Cleal, 2010).

Species: Cf. Odontopteris sp. (Plate XIV, Fig. 1) Only one species shows any similarity with the genus Odontopteris based on the shape of pinnules. Pinnules are more or less triangular, attached to the rachis by their whole base, and make an angle of $50^{\circ}$ to the rachis. The pinnules are relatively small $(4.7 \mathrm{~mm}$ long and $2.8 \mathrm{~mm}$ wide) which is not typical for odontopterid species. The venation is not visible which makes the identification of the specimen rather speculative.

Remarks: The pinnule shape resembles those of the Stephanian species Odontopteris nemejcii (Němejc) Šimůnek and Cleal, O. brardii Brongniart or O. minor Brongniart. However, without knowledge of the venation a detailed comparison cannot be provided.

Species: Paripteris linguaefolia (P. Bertrand 1927) Gothan 1941. (Plate XIV, Figs 2 - 4, 6 - 7)

Remains of this species are fairly common at the studied locality, represented by isolated tongueshaped pinnules, $40-50 \mathrm{~mm}$ long and $10-14 \mathrm{~mm}$ wide. Variation in the size and shape of the pinnules can be explained by their different positions in the frond. The midvein is not preserved.

Remarks: Paripteris linguaefolia differs from Paripteris gigantea, P. pseudogigantea and $P$. schuetzei in the absence of a strong midrib and having a fan-shaped venation. Paripteris schuetzei and $P$. pseudogigantea also usually have smaller pinnules, a more prominent, coarser venation, and often a vaulted pinnule blade (Šimůnek, 2010).

According to Wagner (1984), Paripteris linguaefolia is an index species for the Bolsovian linguaefolia Zone. Zhang et al. (1993) argue that Paripetris linguaefolia and other paripterid species are only forms of Paripteris gigantea (Sternberg) Gothan. Their opinion is based on the co-occurrence of both these "forms" and others at the same localities in China. On this evidence, they argue that Paripteris gigantea forma linguaefolia occurs also in older strata than Bolsovian is association with "true" Paripteris gigantea.

Species: Linopteris obliqua (Bunbury 1847) Zeiller 1899 (Plate XIV, Fig. 5; Plate XV; Plate XVI, Plate XVII, Fig. 1)

Linopteris obliqua represents one of the most common plant remains at the studied locality. It is represented by isolated pinnules that vary in shape from round, linguaeform, straight to subtriangular (Plate XV, Figs 1, 2). Pinnule length ranges from $6 \mathrm{~mm}$ (Plate XVI, Figs 1,2) to $13 \mathrm{~mm}$ (Plate XVI, Figs 4, 7, 9) and width from 4.5 to 6.2 $\mathrm{mm}$. The pinnules have asymmetric cordate (Plate XVI, Figs 4, 5, 8) or straight bases (Plate XVI, Figs 1, 2, 6, 7, 9), and margins that are longitudinally arched with curled margins (Plate XVI, Fig 5). The abaxial midvein occupies 80 per cent of the pinnule length (Plate XVI, Figs 4, 5), except in the shorter pinnules where it is relatively shorter (Plate XVI, Figs 1, 2). The venation is anastomosing, with lines-of-areolae. Tailed, elongate areolae lie lengthwise with the midvein (Figure 12). Adjacent to these are elongate areolae of variable shape, including hexagonal and septangular meshes and toward the pinnule-margin areolae gradually decrease in size. Areolae at the pinnule margin are consistently elongate, open-ended.

\section{Plate XIII}

1) Alethopteris sp. [? cf. grandinii (Brongniart, 1828) Goeppert, 1836]; specimen B1902; Museo Civico di Storia Naturale (Milan); scale bar $5 \mathrm{~mm}$; 2) Alethopteris sp. A.; Museo Civico di Storia Naturale (Milan); specimen B1788; scale bar $5 \mathrm{~mm}$; 3) Alethopteris sp. B; Museo Civico di Storia Naturale (Milan); specimen B1771; scale bar 5 mm; 4) Neuralethopteris cf. larischii; Museo Civico di Storia Naturale (Milan); specimen B1893; scale bar $5 \mathrm{~mm}$; 5) Alethopteris sp. [? cf. grandinii (Brongniart, 1828) Goeppert, 1836]; Museo Civico di Storia Naturale (Milan); specimen B1894; scale bar 5 mm; 6) Alethopteris sp. A.; Museo Civico di Storia Naturale (Milan); specimen B1913; scale bar $5 \mathrm{~mm}$; 7) Alethopteris sp. [? cf. grandinii (Brongniart, 1828) Goeppert, 1836]; Museo Civico di Storia Naturale (Milan); specimen B1913; scale bar 5 mm; 8) Alepthopteris sp. B; specimen B1902; the Museo Etnografico e Naturalistico Val Sanagra; scale bar $10 \mathrm{~mm}$. 
Folia vol. 46, No. 1-2, 2012

\section{Plate XIV}

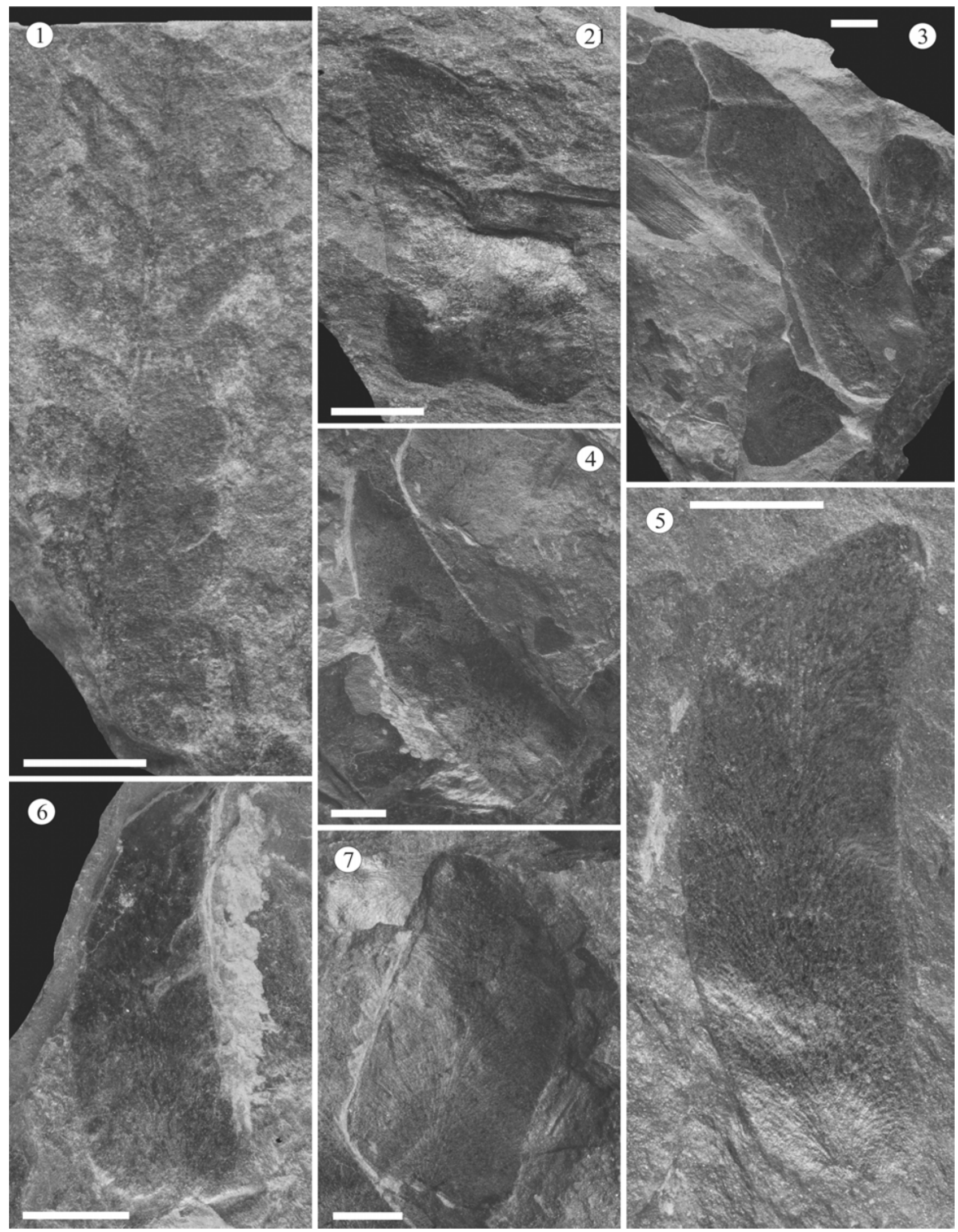




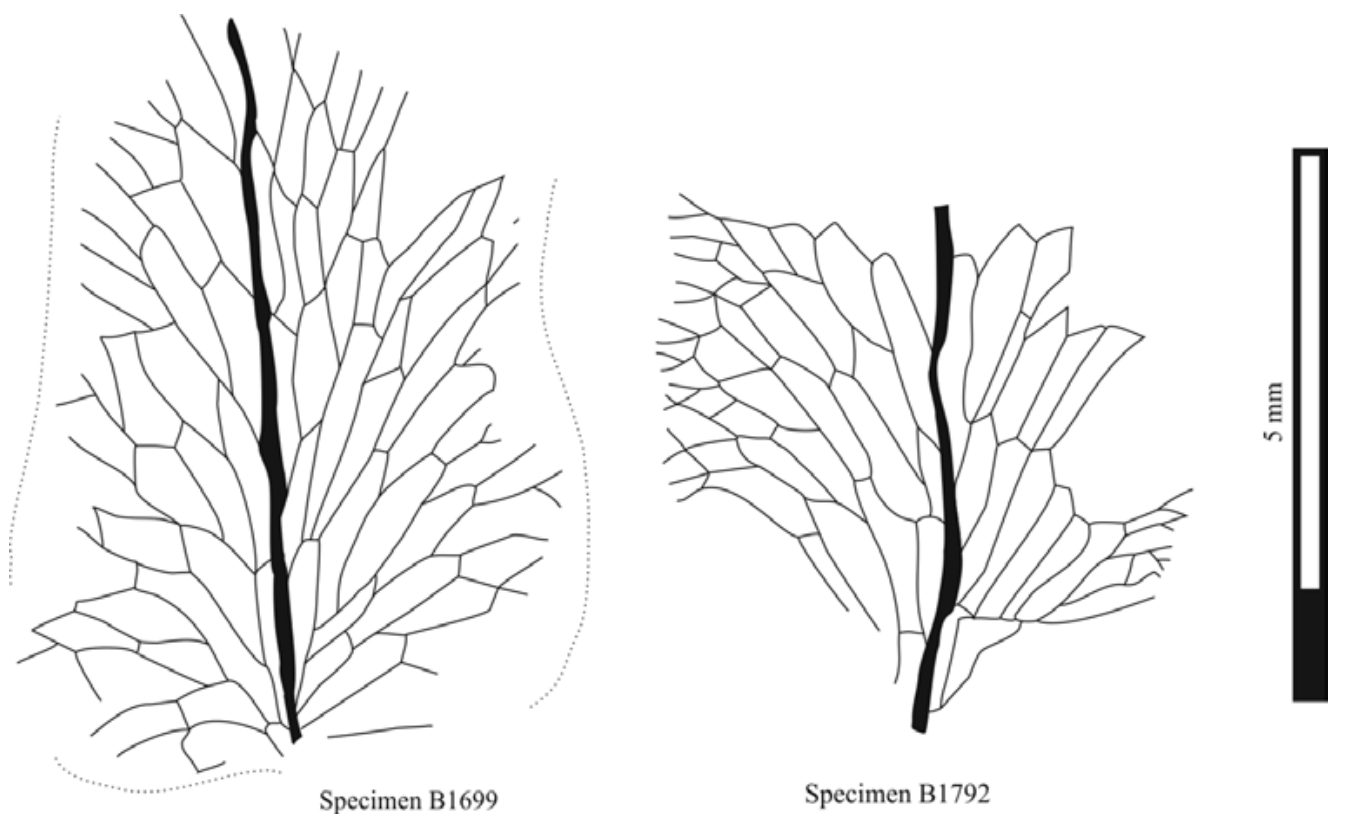

Figure 12. The anastomosed venation of Linopteris obliqua, with the lines-of-areolate. Tailed, elongate areolae lie lengthwise with the midvein. The elongate areolae are variable in shape, including hexagonal and septangular meshes and toward the pinnule-margin areolae gradually decrease in size. Areolae at the pinnule margin are consistently elongate, open-ended; camera lucida.

The association of pinnules of different shapes indicates that these pinnules come from the same species, but from different parts of the plant. This phenomenon is also shown in Zodrow et al. (2007). Figure 1 on the Plate XVII shows two poorly preserved pollen organs in organic connection to a rachis with some Linopteris obliqua pinnules still attached.

Pollen organs consist of several elongated, banana-shaped microsporangia, $7 \mathrm{~mm}$ long and $0.7 \mathrm{~mm}$ wide. The number of microsporangia per pollen organ cannot be exactly given but it appears number more than 10. Laveine et al. (1993) reported a great abundance of Potoniea Zeiller associated with Linopteris pinnules. Nevertheless, our pollen organ compared with the genus Potoniea is too small.
Remarks: Linopteris obliqua stratigraphically ranged from lower Moscovian (Uppermost Duckmantian) (Fissunenko and Laveine, 1984) to Uppermost Moscovian (Asturian) (Zodrow et al., 2007). Specimen B1714 shows a very interesting pinnule form with anastomosed venation, with the linesof-areolate. The pinnule is very long $(20 \mathrm{~mm})$ and narrow $(3.2 \mathrm{~mm})$ (Figure 13). The pinnule could represent an aberrant for of Linopteris obliqua, an opinion that would be supported by the venation pattern which corresponds with that species.

Remarks: The specimen B1714 (Plate XVI, Fig. 3) is comparable with pinnule dimensions to Linopteris linearis Wagner from near the Westphalian/ Stephanian boundary strata of NW Spain (Wagner, 1964). The venation of both species is very similar, however on Spanish species is better preserved.

\section{Plate XIV}

1) Cf. Odontopteris sp.; specimen B1894; Museo Civico di Storia Naturale (Milan); scale bar 5 mm; 2) Paripteris linguaefolia; Museo Civico di Storia Naturale (Milan); specimen B1714; scale bar $5 \mathrm{~mm}$; 3) Paripteris linguaefolia; Museo Civico di Storia Naturale (Milan); specimen B1887; scale bar $5 \mathrm{~mm}$; 4) Paripteris linguaefolia; Museo Civico di Storia Naturale (Milan); specimen B1887; scale bar 5 mm; 5) Linopteris obliqua; Museo Civico di Storia Naturale (Milan); specimen B1895; scale bar $5 \mathrm{~mm}$; 6) Paripteris linguaefolia; Museo Civico di Storia Naturale (Milan); specimen B1895; scale bar $5 \mathrm{~mm}$; 7) Paripteris linguaefolia; Museo Civico di Storia Naturale (Milan); specimen B1887; scale bar 5 mm. 

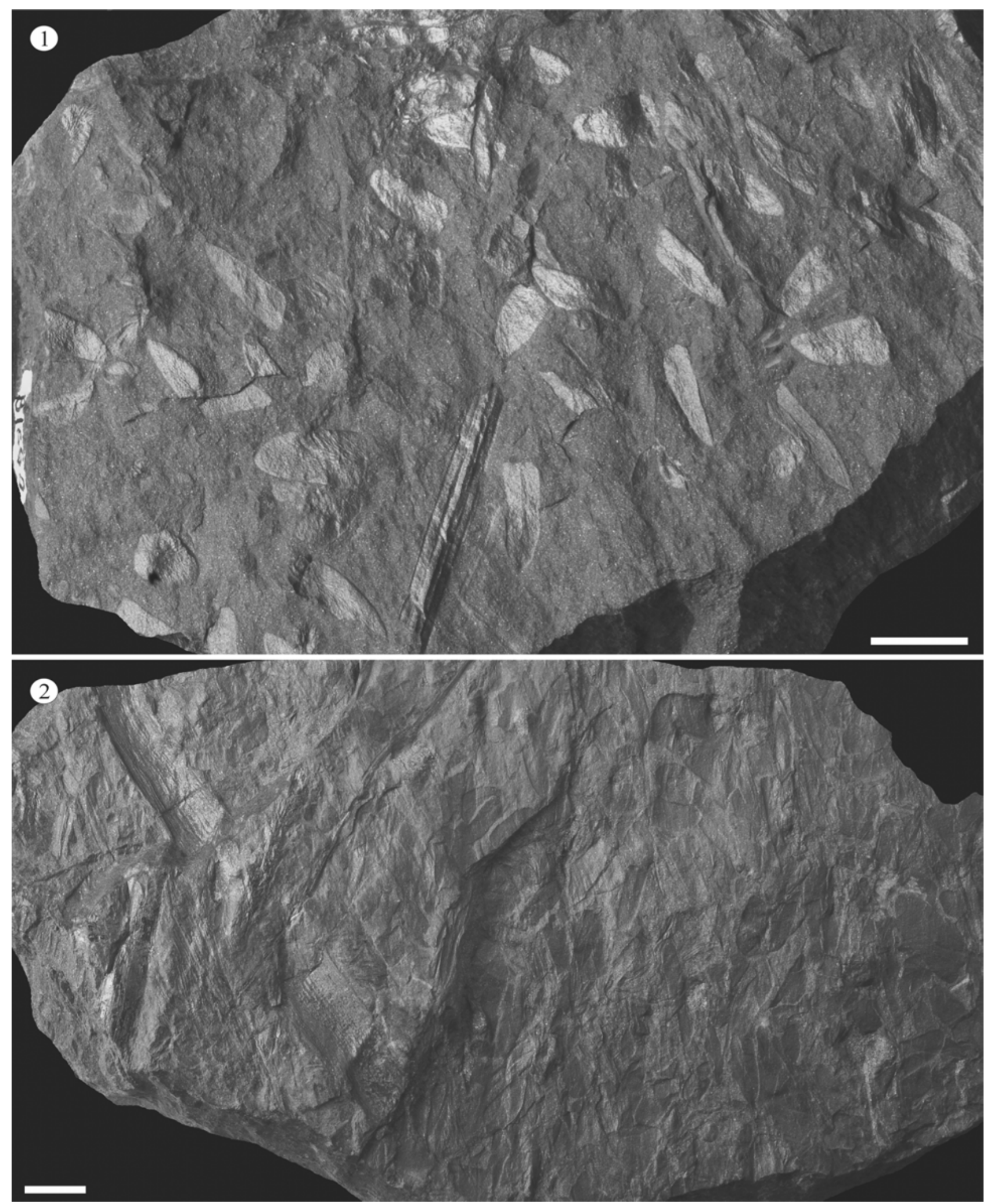

\section{Plate XV}

1) Linopteris obliqua; Museo Civico di Storia Naturale (Milan); specimen B1660; scale bar 10 mm; 2) Linopteris obliqua; Museo Civico di Storia Naturale (Milan); specimen B1995; scale bar $10 \mathrm{~mm}$. 


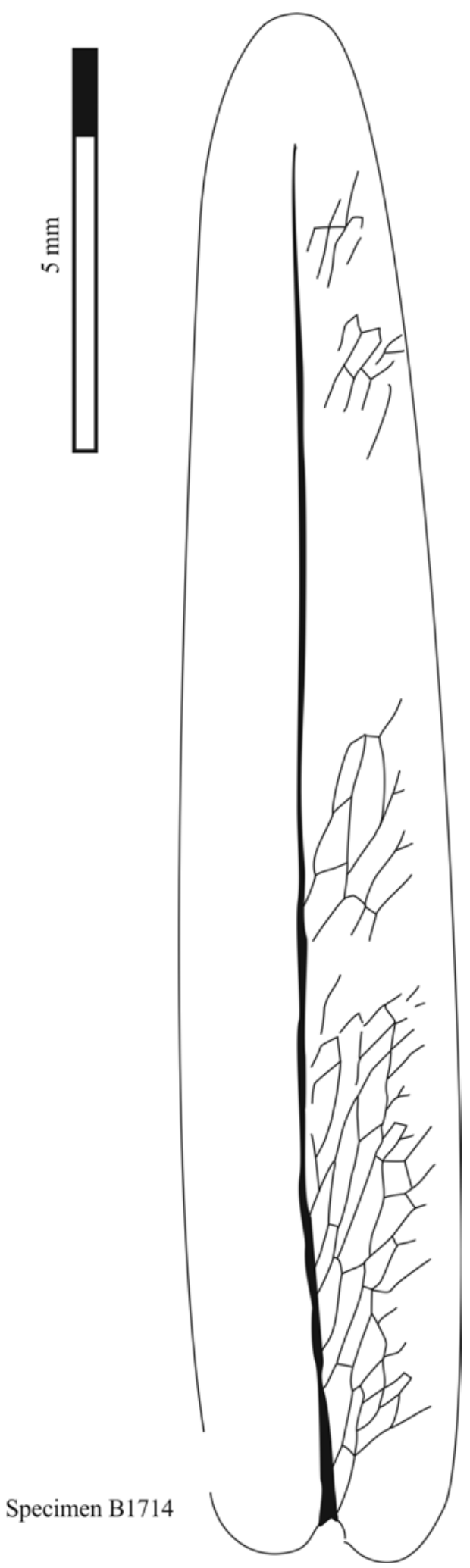

Figure 13. Leave of Linopteris sp. with anastomosed venation and lines-of-areolate. Pinnule is very long and narrow.
Species: Hexagonocarpus sp. (Plate XVII, Fig. 2) One specimen compares with the Hexagonocarpus figured by Zodrow et al. (2007, fig. 23, A). Zodrow linked this seed with Linopteris obliqua foliage, which could agree with the fact that this species is the commonest type of foliage at the present locality. The seed has a diameter of $15 \mathrm{~mm}$ and three narrow longitudinal ribs (sclerotesta).

\section{Pteridospem seeds}

Species: Trigonocarpus spp. (Plate XVII, Figs 3, 4) Seeds were probably radially symmetrical (presently preserved as compressions), elongate, and longer than broad. The testa is differentiated into a soft outer sarcotesta and hard inner sclerotesta. Only the sclerotesta is preserved with prominent longitudinal, equidistant grooves (Crookall, 1976). Both illustrated specimens represent different species. The seed on Plate XVII, Fig. 3 is $21 \mathrm{~mm}$ long and $5.5 \mathrm{~mm}$ wide; the seed on Plate XVII, Fig. 4 is $15 \mathrm{~mm}$ long and $5 \mathrm{~mm}$ wide.

Species Carpolithus sp. (Plate XVII, Fig. 5)

This seed is $20 \mathrm{~mm}$ long and $10 \mathrm{~mm}$ wide. It is of a quite different type in comparison with the Trigonocarpus species, as the inner sclerotesta does not show prominent, longitudinal equidistant grooves.

\section{Order: Cordaitanthales}

\section{Family: Cordaitantaceae}

\section{Species: Cordaites sp.(Plate Plate XVIII)}

Determination of species of the genus Cordaites is always difficult without knowledge of cuticles; as was documented by Šimůnek (2007), the venation alone is not sufficient for species determination. The preserved venation is a result of taphonomy and mode of preservation of Cordaites leaves before burial. Such long leaves underwent some maceration before burial that could influence the state of preservation. It seems that two types occur in the Val Sanagra locality. The first (Plate XVIII, Figs 1, 2) has venation of the "palmaeformis" type. with relatively dense, fine veins (about 40 vein per $10 \mathrm{~mm}$ ). The second (Plate XVIII, Figs 3,4 ) has a venation consisting of alternating thick and thin veins (Josten, 1991) of the "principalis" type. The density of thick veins is about 15 veins per $10 \mathrm{~mm}$.

Remarks: These venation types have no stratigraphical significance, and range from the upper Namurian to the Permian. 
Folia vol. 46, No. 1-2, 2012

\section{Plate XVI}
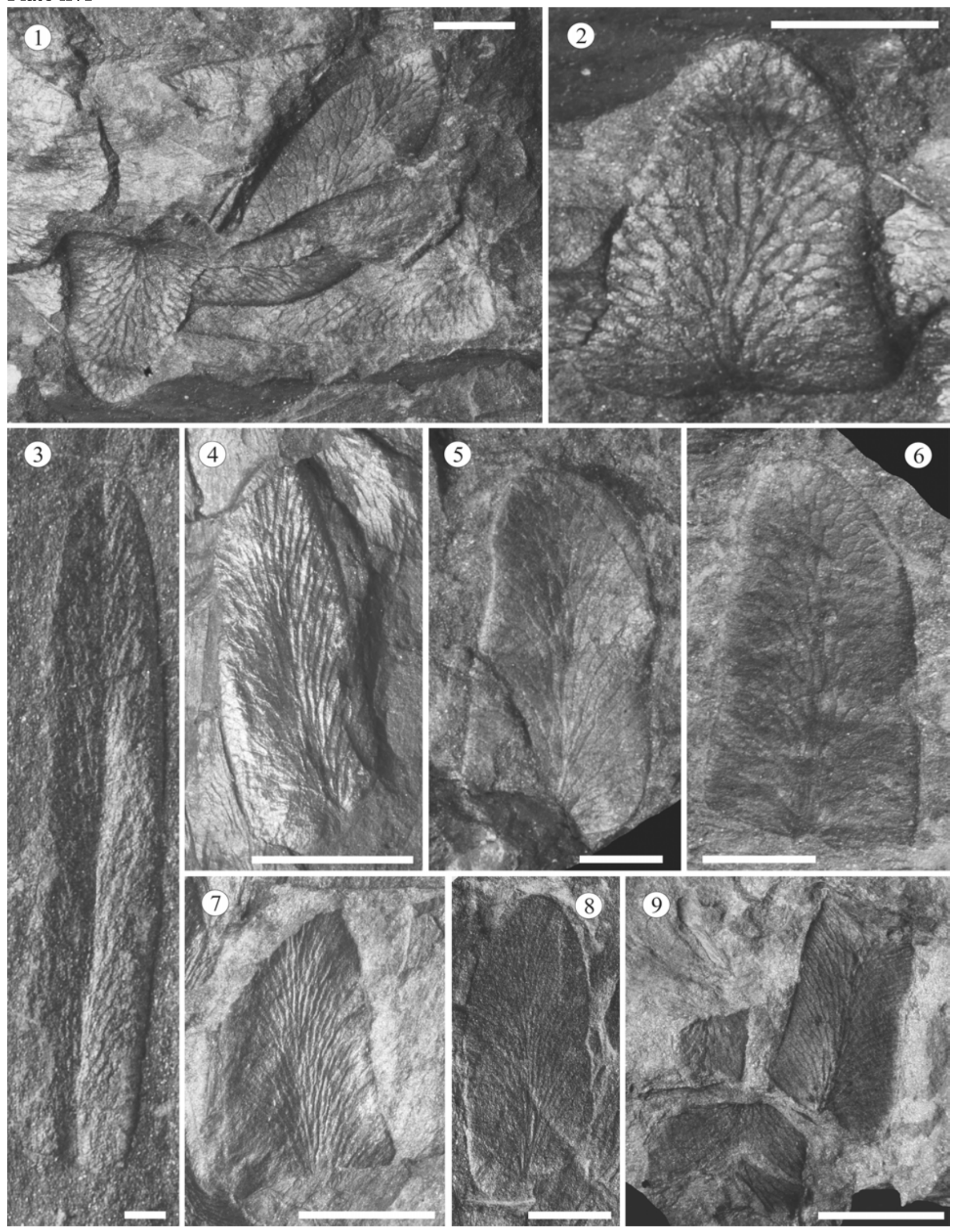


\section{DISCUSSION}

Since the first report of Pennsylvanian macrofloras (Calamites, Sigillarie and Lepidodendron) from the studied locality (Magnani, 1946), many species have been described. Venzo \& Maglia (1947) greatly upgraded the list of species from here, describing around 70 fossil species (Table 1), again with a clear dominance of lycopsids. Later Venzo (1951) revised material from the locality and added several new species to the list (Table 1). In this present revision we have distinguished about 43 fossil species, which is more than Sordelli (1896) described from Manno (Canton Ticino, Switzerland) but less than those identified by Venzo (1951) in Val Sanagra. The high number of species identified by Venzo could not be confirmed by our revision, mainly because the generally poor preservation makes identification of the fossils problematic. Venzo probably took small differences caused either by deformation of the plant remains due to a strong tectonic overprint of the fossil-bearing strata, or simply related to natural variability within species, as a justification for identification of different species. Due to this fact, the number of species (especially among the lycopsids and sphenopsids) described by Venzo \& Maglia (1947) and Venzo (1951) has been reduced after a careful revision. Nevertheless, there are some species that are mentioned in all the papers including the present one. These common species are as follows: Sigillaria rugosa, Sigillaria tessellata, Lepidodendron aculeatum, Lepidocarpon cf. majus, Stigmaria ficoides, Calamites (Crucicalamites) cruciatus, Calamites (Stylocalamites) cisti, Annularia radiata, Asterophyllites equisetiformis, Lobatopteris miltonii, Senftenbergia plumosa and Linopteris obliqua. In addition, following species are described for the first time from the locality: Sigillaria cf. inferior, Sigillaria cf. ovata, Asolanus camptotaenia, Lepidodendron cf. acutum, Bothrodendron sp., Calamites (Diplocalamites) carinatus, Asterophyllites longifolius, Calamostachys cf. tuberculata, Lobatopteris cf. simonii, Pecopteris microphylla, Corynepteris (Alloiopteris) sp., Eusphenopteris cf. neuropteroides, Mariopteris cf. lobatifolia, Mariopteris ef. sauveurii, Karinopteris dernoncourti, Alethopteris sp. [? cf. grandinii (Brongniart, 1828) Goeppert, 1836], Neuralethopteris cf. larischii, Paripteris linguaefolia or Hexagonocarpus sp.

Zygopterids, which as a group of ferns, have never been mentioned previously from the Val Sanagra locality. We discovered only two poorly preserved specimens of the genus Corynepteris but it is clear evidence that this type of fern was present in the plant assemblage.

Previous authors described two species of $\mathrm{Li}$ nopteris - L. obliqua and L. neuropteroides. Nevertheless, our research shows that all pinnule remains of the linopterid species probably belong to one species $L$. obliqua. Its pinnules are commonly associated with the other species from different plant group. The pinnules identified as L. neuropteroides are mixed with pinnules, which are referred to L. obliqua on the same specimen. Venation diagrams of the pinnules made by camera lucida show some differences between pinnules preserved showing the adaxial and abaxial sides, as already described by Zodrow et al. (2007). Due to this fact we assume that only one linopterid species inhabited the original environment. The presence of pollen organ attached directly to ultimate rachis and accompanied by pinnules is interesting because it represents quite a different model from that described by Laveine (1993). He reconstructed fertile pollen part as isolated fertile "fronds" that lacked pinnules.

Collected rock samples containing fossils and a simple graphic documentation and description of the Val Sanagra section allow only a very general conclusion concerning the sedimentary paleoenvironment and habitats colonized by the plants. Available data indicate the existence of a wide

\section{Plate XVI}

1) Linopteris obliqua; Museo Civico di Storia Naturale (Milan); specimen B1605; scale bar 3 mm; 2) Linopteris obliqua; Museo Civico di Storia Naturale (Milan); specimen B1605; scale bar $3 \mathrm{~mm}$; 3) Linopteris obliqua; Museo Civico di Storia Naturale (Milan); specimen B1714; scale bar $1 \mathrm{~mm}$; 4) Linopteris obliqua; Museo Civico di Storia Naturale (Milan); specimen B1962; scale bar $5 \mathrm{~mm}$; 5) Linopteris obliqua; Museo Civico di Storia Naturale (Milan); specimen B1659; scale bar $2 \mathrm{~mm}$; 6) Linopteris obliqua; Museo Civico di Storia Naturale (Milan); specimen B1659; scale bar $3 \mathrm{~mm}$; 7) Linopteris obliqua; Museo Civico di Storia Naturale (Milan); specimen B1962; scale bar $5 \mathrm{~mm}$; 8) Linopteris obliqua; Museo Civico di Storia Naturale (Milan); specimen B1995; scale bar 5 mm; 9) Linopteris obliqua; Museo Civico di Storia Naturale (Milan); specimen B1782; scale bar $5 \mathrm{~mm}$. 
Folia vol. 46, No. 1-2, 2012

\section{Plate XVII}
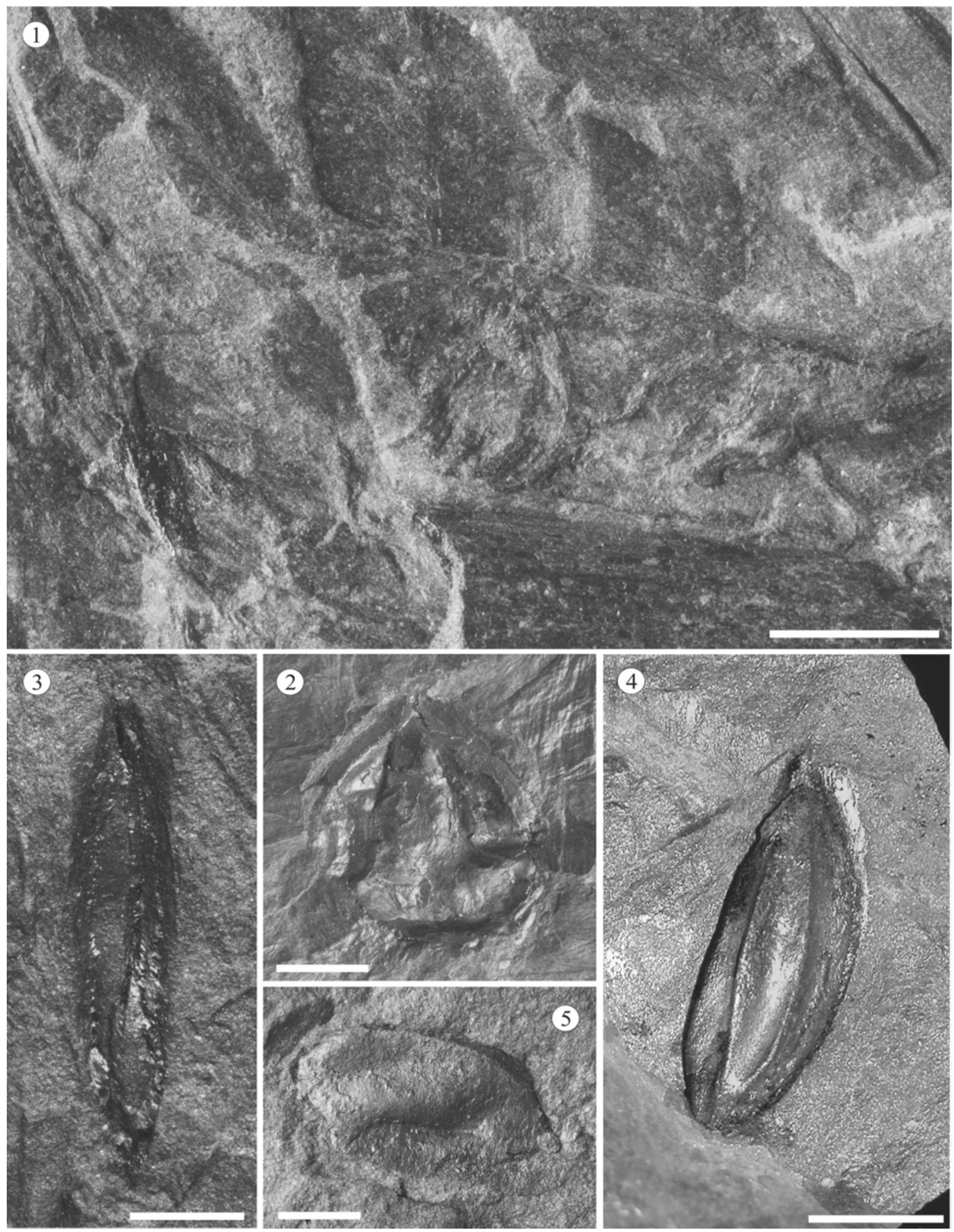
range of lithologies from mudstones to conglomerates deposited in environments with variable dynamics. Fine-grained sediments are represented by massive and bedded mudstones, often with mica. Bedded mudstones are dark grey and often contain drifted plant remains, either concentrated on a single bedding plane, or scattered. Roots are rare or absent. Massive mudstones and siltstones are either nearly without plant remains or usually contain appendices and rhizomes of arborescent lycopsids thus representing stigmarian root horizons probably underlying coal seams. Both these texturally different lithologies probably represent floodplain (or delta plain) sediments. Those without roots with drifted flora represent sediments of shallow floodplain lakes, whereas rooted mudstones represent aerially exposed parts of floodplains. Sandy admixture in some mudstones indicates the influence of a clastic source, probably an active channel. Locally common biotite may indicate a volcanic admixture, or may be simply of detrital origin.

Siltstones laminae often alternate with finegrained sandstone or grade to fine-grained laminated sandstone. Rootlets are common as well as some aerial plant remains. Coarse-grained sandstones and conglomerates rich in feldspar with clasts commonly around $3-4 \mathrm{~mm}$ and scattered pebbles around $10 \mathrm{~mm}$ in diameter contain remains of massive plant axes. The affinities of these massive axes are not always determinable even within the collected specimens, but those which can be determined are mostly decorticated ribbed sigillarian and much less commonly lepidodendrid stems. Those without "ornamentation" may represent also cordaites or pteridosperms. These coarse lithologies with coalified trunks suggest the presence of vegetation in proximity to the bed-load dominating fluvial channels. Domination of certain plant taxa remains (e.g. isolated sigillarian leaves or Linopteris pinnules) indicate the existence of partitioned habitats colonized by various plant assemblages dominated by pteridosperms and calamites, or by arborescent lycops- ids, mostly sigillarians or less commonly lepidodendrids (mostly Paralycopodites). Such ecological differentiation of vegetation is a common feature described from many coalfields and we assume it existed also in the Val Sanagra locality (e.g. DiMichele and Philips, 1994). The Carboniferous deposits at Val Sanagra are only a thin tectonic slice of a once thicker sedimentary complex. It is therefore difficult to make any serious conclusions about the basin type and its development. However, the absence of marine fauna in the locality suggests this was formerly a part of a continental ba$\sin$. This is also in agreement with relatively high content of feldspatic sandstones indicating a close proximity of feldspar source. In other European coalfields, feldspatic sandstones are typical for continental basins rather than for the paralic ones. We therefore assume that Val Sanagra sediments represent part of a succession deposited in a continental setting in a fluvial environment with a well-developed and vegetated floodplain with clastic substrates that locally/occasionally changed into peat swamps.

\section{STRATIGRAPHICAL RELEVANCE}

Venzo and Maglia (1947) placed the flora from Val Sanagra locality in the late Westphalian, (Westphalian C, i.e. Middle Moscovian). Our revision of the Val Sanagra flora shows that it contains elements which have their last appearance in the uppermost Duckmantian. The best examples are representatives of the genus Neuralethopteris larischii, Karinopteris dernoncourti and Sigillaria ovata. The Duckmantian Substage is also indicated by the rich occurrence of rhytidolepis and subrhytidolepis sigillarias although most of the identified species range up into the Bolsovian. They tend not to be so common there as in stratigraphically lower levels. There are some other species, which are typical for the Duckmantian Substage, however, their last appearance occurs within the Bolsovian Substage (Table 2). These are Sigillaria inferior, Lepidodendron acutum, Eusphenopteris

\section{Plate XVII}

1) The pollen organs of Linopteris obliqua; Museo Civico di Storia Naturale (Milan); specimen B1995; scale bar 5 mm; 2) Hexagonocarpus sp.; Museo Civico di Storia Naturale (Milan); specimen B1962; scale bar 5 mm; 3) Trigonocarpus sp.; Museo Civico di Storia Naturale (Milan); specimen B1985; scale bar $5 \mathrm{~mm}$; 4) Trigonocarpus sp.; the Museo Etnografico e Naturalistico Val Sanagra; scale bar 5 mm; 5) Carpolithus sp.; Museo Civico di Storia Naturale (Milan); specimen B1985; scale bar $5 \mathrm{~mm}$. 
Folia vol. 46, No. 1-2, 2012

\section{Plate XVIII}
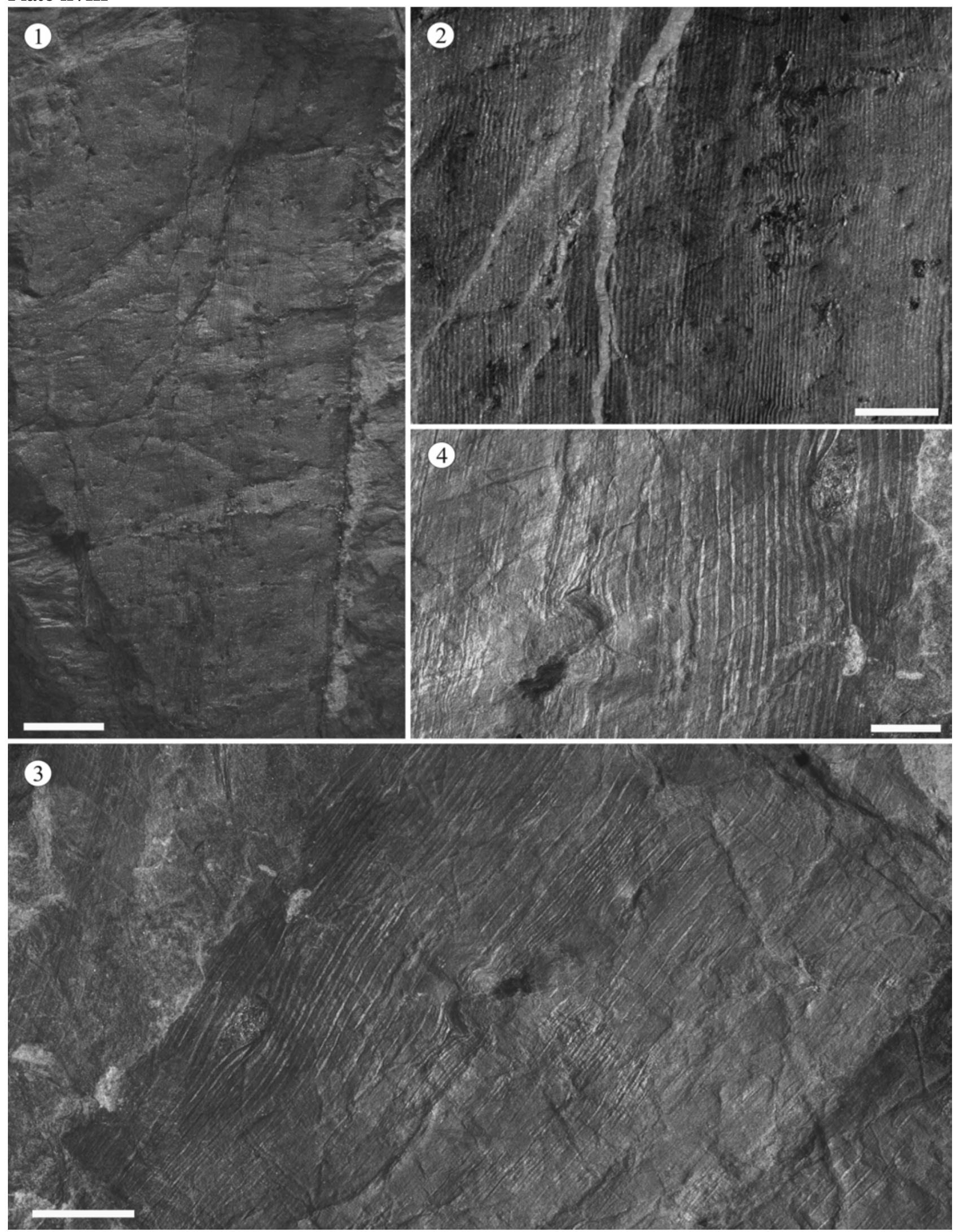
neuropteroides and Lobatopteris miltonii. Typical of the Bolsovian Substage are Mariopteris latifolia and Paripteris linguaefolia, whereas Pecopteris microphylla or Alethopteris sp. [? cf. grandinii (Brongniart, 1828) Goeppert, 1836] start their occurrence in the Bolsovian Substage. Calamostachys tuberculata is usually associated with late Moscovian floras, but is normally accompanied by Annularia stellata, which is absent in Val Sanagra; the determination of $C$. tuberculata is, therefore, not very reliable here. As a whole, the predominance of rhytidolepis sigillarias and species typical for Duckmantian or Bolsovian substages, suggest that the Val Sanagra flora spans the interval between the Duckmantian and Bolsovian Substages (middle Moscovian).

Val Sanagra flora thus belongs among the oldest Pennsylvanian floras of Southern Alps. Interesting is the biostratigraphical comparison of the Val Sanagra flora with that found in the Manno locality (Canton Ticino, Switzerland), since the age-attribution of both has been a matter of debate for a long time. The first discoveries from the above-cited Swiss fossiliferous locality were made by Heer (1876), who listed Calamites cisti, Sigillaria elongata and S. elegans. Some years later Sordelli (1896), recognized 13 species (see Table 1), ten of which are shared in common with the flora from the Alpe Logone/Val Sanagra, including five species of Sigillaria, and another five species of $C a$ lamites, Lepidodendron and Cordaites. He attributed the Manno flora to the early Stephanian, but with many Westphalian elements. Further studies were made later by Escher (1911) who confirmed the presence of Calamites cisti, and Sigillaria elongata, but attributed the last species to $S$. tessellata.

Venzo \& Maglia (1947) compared their taxonomic list with that of Sordelli (1896) and concluded that the Val Sanagra flora was older than that from Manno. Venzo (1951) later ascribed the Manno flora to the transition between the Westphalian $\mathrm{B}$ and $\mathrm{C}$ substages, thus suggesting it to be slightly older than the flora from Alpe Logone. Jong- mans (1950), related the floras of various Swiss localities (including Manno), first to the Westphalian B-C due to the presence of some elements such as Linopteris neuropteroides, Pecopteridium, Sigillariophyllum, Cordaites cf. borassifolius, but later considered it to be slightly younger, most likely Westphalian C ("Mittleres Westphalien", Jongmans, 1960, p. 95). The taxonomic revision made in this paper, together with lithostratigraphical affinities of the two localities, permits a clear chronostratigraphic correlation, hence denying any age-difference between them.

\section{ACKNOWLEDGEMENT}

The authors thank Paolo Arduini, Alessandro Garassino, Giorgio Teruzzi (Museo Civico di Storia Naturale di Milano) and Attilio Selva (Museo Etnografico e Naturalistico Val Sanagra, Grandola ed Uniti) for their help with the collections and obtaining information. G. Cassinis (Pavia University) is also acknowledged by AR for a fruitful discussion on the geology of the area and to tirelessly stimulating us in revising this flora and re- investigating the Pennsylvanian outcrops of W Southern Alps. G. Santi (Pavia University) gave a fundamental contribution in the picturing of samples in the Museum of Milano and Val Sanagra. R. Gianotti (Pavia University) is thanked for his thoughtful suggestions and for the time spent on excursion on some Pennsylvanian outcrop to the $\mathrm{W}$ of the area. Thanks also go to E. L. Zodrow (Nova Scotia, Canada) for the consultation of linopterid species. The visit of the collection in the Museo Civico di Storia Naturale di Milano by two of the authors (Stanislav Oplištil and Josef Pšenička) was enabled with financial support of the grant project of the Grant Agency of the Czech Republic (GACR) P210/11/1431. This paper is a contribution to the IGCP 575 project, Pennsylvanian terrestrial habitats and biotas of southeastern Euramerica. We also thank the reviewers Chris Cleal and Erwin L. Zodrow for their useful comments and grammar revision.

\section{Plate XVIII}

1) Cordaites sp.; Museo Civico di Storia Naturale (Milan); specimen B1858; scale bar $10 \mathrm{~mm}$; 2) Cordaites sp.; Museo Civico di Storia Naturale (Milan); specimen B1858; scale bar 5 mm; 3) Cordaites sp.; Museo Civico di Storia Naturale (Milan); specimen B1919; scale bar 10 mm; 4) Cordaites sp.; Museo Civico di Storia Naturale (Milan); specimen B19195; scale bar $5 \mathrm{~mm}$. 
Table 1

List of species published by several authors and the actual list of species. The gray fields represent the common species.

\begin{tabular}{|c|c|c|c|c|c|}
\hline & & $\begin{array}{c}\text { Sordelli } \\
1896\end{array}$ & $\begin{array}{c}\text { Venzo } \\
\text { and } \\
\text { Maglia } \\
1947\end{array}$ & $\begin{array}{c}\text { Venzo } \\
1951\end{array}$ & $\begin{array}{l}\text { present } \\
\text { work }\end{array}$ \\
\hline \multirow[t]{39}{*}{ Lycopsida } & Sigillaria rugosa & $\mathrm{x}$ & $\mathrm{x}$ & & $\mathrm{x}$ \\
\hline & Sigillaria cf. inferior & & & & $\mathrm{x}$ \\
\hline & Sigillaria cf. ovata & & & & $\mathrm{x}$ \\
\hline & Sigillaria tessellata & $\mathrm{x}$ & $\mathrm{x}$ & $\mathrm{x}$ & $\mathrm{x}$ \\
\hline & Sigillaria pachyderma & $\mathrm{x}$ & & & \\
\hline & Sigillaria cf. micaudi & & $\mathrm{x}$ & & $\mathrm{x}$ \\
\hline & Sigillaria ocellata & $\mathrm{x}$ & & & \\
\hline & Sigillaria elongata & $\mathrm{x}$ & & $\mathrm{x}$ & \\
\hline & Sigillaria elongata $f$. minor & & $\mathrm{x}$ & & \\
\hline & Sigillaria deutschiana & $\mathrm{x}$ & $\mathrm{x}$ & & \\
\hline & Sigillaria cf. transversalis & & $\mathrm{x}$ & $\mathrm{x}$ & \\
\hline & Sigillaria cf. saulli & & & $\mathrm{x}$ & \\
\hline & Sigillaria cf. diploderma & & $\mathrm{x}$ & $\mathrm{x}$ & \\
\hline & Sigillaria reniformis & & $\mathrm{x}$ & & \\
\hline & Sigillaria principis & & $\mathrm{x}$ & & \\
\hline & Sigillaria principis f. reticolata & & $\mathrm{x}$ & & \\
\hline & Sigillaria scutellata & & $\mathrm{x}$ & & \\
\hline & Sigillaria scutellata f. elliptica & & $\mathrm{x}$ & & \\
\hline & Sigillaria laevigata & & $\mathrm{x}$ & & \\
\hline & Sigillaria sauveri & & $\mathrm{x}$ & & \\
\hline & Sigillaria intermedia & & $\mathrm{x}$ & & \\
\hline & Sigillaria nudicaulis & & $\mathrm{x}$ & & \\
\hline & Asolanus camptotaenia & & & & $\mathrm{x}$ \\
\hline & Lepidodendron aculeatum & $\mathrm{x}$ & & $\mathrm{x}$ & $\mathrm{x}$ \\
\hline & Lepidodendron cf. acutum & & & & $\mathrm{x}$ \\
\hline & Lepidodendron cf. dichotomum & & $\mathrm{x}$ & & \\
\hline & Lepidodendron distatus & & $\mathrm{x}$ & & \\
\hline & Lepidodendron cf., obovatum & & & $\mathrm{x}$ & \\
\hline & Lepidodendron cf. nathorsti & & $\mathrm{x}$ & & \\
\hline & Lepidodendron cf. ophiurus & & & & \\
\hline & Sublepidodendron cf. elegans & & $\mathrm{x}$ & & \\
\hline & Lepidophloias cf. laricinus & & $\mathrm{x}$ & $\mathrm{x}$ & \\
\hline & Lepidophloios macrolepidotus & & & $\mathrm{x}$ & \\
\hline & Lepidophloios cf. acerosus & & & $\mathrm{x}$ & \\
\hline & Lepidophloios sp. & & & & $\mathrm{x}$ \\
\hline & Ulodendron cf. minus & & $\mathrm{x}$ & & \\
\hline & Pinacodendron cf. ohmanni & & & $\mathrm{x}$ & \\
\hline & Halonia cf. tortuosa & & $\mathrm{x}$ & & \\
\hline & Halonia sp. & & & & $\mathrm{x}$ \\
\hline
\end{tabular}




\begin{tabular}{|c|c|c|c|c|c|}
\hline & & $\begin{array}{c}\text { Sordelli } \\
1896\end{array}$ & $\begin{array}{c}\text { Venzo } \\
\text { and } \\
\text { Maglia } \\
1947 \\
\end{array}$ & $\begin{array}{c}\text { Venzo } \\
1951\end{array}$ & $\begin{array}{l}\text { present } \\
\text { work }\end{array}$ \\
\hline & Arctodendron kidstoni & & $\mathrm{x}$ & & \\
\hline & Lepidocarpon cf. majus & & $\mathrm{x}$ & $\mathrm{x}$ & $\mathrm{x}$ \\
\hline & Lepidocarpon sternbergi & & $\mathrm{x}$ & & \\
\hline & Lepidocarpon lanceolatum & & & $\mathrm{x}$ & \\
\hline & Lepidostrobus sp. & & & $\mathrm{x}$ & \\
\hline & Stigmaria ficoides & & $\mathrm{x}$ & $\mathrm{x}$ & $\mathrm{x}$ \\
\hline & Stigmaria ficoides f. rimosa & & & $\mathrm{x}$ & \\
\hline & Stigmaria ficoides $f$. laevis & & & $\mathrm{x}$ & \\
\hline & Stigmariopsis & & & $\mathrm{x}$ & \\
\hline & Knorria imbricata & & $\mathrm{x}$ & & \\
\hline & Knorria sp. & & $\mathrm{x}$ & & $\mathrm{x}$ \\
\hline & Bergeria feistmanteli & & $\mathrm{x}$ & & \\
\hline & Aspidiaria sp. & & $\mathrm{x}$ & & \\
\hline & Bothrodendron sp. & & & & $\mathrm{x}$ \\
\hline \multirow[t]{24}{*}{ Sphenopsida } & Calamites (Diplocalamites) carinatus & & & & $\mathrm{x}$ \\
\hline & Calamites (Crucicalamites) cruciatus & & $\mathrm{x}$ & $\mathrm{x}$ & $\mathrm{x}$ \\
\hline & Calamites (Stylocalamites) cisti & $\mathrm{x}$ & $\mathrm{x}$ & $\mathrm{x}$ & $\mathrm{x}$ \\
\hline & Calamites (Stylocalamites) suckowi & & $\mathrm{x}$ & $\mathrm{x}$ & \\
\hline & Calamites (Stylocalamites) jubatus & & $\mathrm{x}$ & & \\
\hline & C. ramosus forma monobrachiatus & & $\mathrm{x}$ & & \\
\hline & Calamites (Calamitina) schützeiformis & & $\mathrm{x}$ & & \\
\hline & $\begin{array}{l}\text { Calamites (Calamitina) schützeiformis } \\
\text { f. intermedius }\end{array}$ & & & $\mathrm{x}$ & \\
\hline & $\begin{array}{l}\text { Calamites (Calamitina) schützeiformis } \\
\text { f. waldenburgensis }\end{array}$ & & & $\mathrm{x}$ & \\
\hline & Calamites (Calamitina) undulatus & & $\mathrm{x}$ & $\mathrm{x}$ & \\
\hline & Annularia sphenophylloides & & & $\mathrm{x}$ & \\
\hline & Annularia radiata & & $\mathrm{x}$ & $\mathrm{x}$ & $\mathrm{x}$ \\
\hline & Asterophyllites longifolius & & & & $\mathrm{x}$ \\
\hline & Calamostachys cf. tuberculata & & & & $\mathrm{x}$ \\
\hline & Asterophyllites equisetiformis & & $\mathrm{x}$ & $\mathrm{x}$ & $\mathrm{x}$ \\
\hline & Arthropitys cannaeformis & $\mathrm{x}$ & $\mathrm{x}$ & & \\
\hline & Arthropitys approximates & $\mathrm{x}$ & $\mathrm{x}$ & & \\
\hline & Arthropitys gigas & $\mathrm{x}$ & & & \\
\hline & Sphenophyllum sp. & & $\mathrm{x}$ & $\mathrm{x}$ & \\
\hline & Palaeostachya elongata & & $\mathrm{x}$ & & \\
\hline & Palaeostachya aff. schültzi & & $\mathrm{x}$ & & \\
\hline & Calamostachys germanica & & $\mathrm{x}$ & & \\
\hline & Calamostachys ramosa & & $\mathrm{x}$ & $\mathrm{x}$ & \\
\hline & Calamostachys sp. cfr. tubercolata & & $\mathrm{x}$ & & \\
\hline \multirow[t]{3}{*}{ ferns } & Lobatopteris cf. simonii & & & & $\mathrm{x}$ \\
\hline & Lobatopteris miltonii & & $\mathrm{x}$ & $\mathrm{x}$ & $\mathrm{x}$ \\
\hline & Pecopteris microphylla & & & & $\mathrm{x}$ \\
\hline
\end{tabular}




\begin{tabular}{|c|c|c|c|c|c|}
\hline & & $\begin{array}{c}\text { Sordelli } \\
1896\end{array}$ & $\begin{array}{c}\text { Venzo } \\
\text { and } \\
\text { Maglia } \\
1947\end{array}$ & $\begin{array}{c}\text { Venzo } \\
1951\end{array}$ & $\begin{array}{c}\text { present } \\
\text { work }\end{array}$ \\
\hline & Pecopteris cf. daubreei & & $\mathrm{x}$ & & \\
\hline & Pecopteris cf. arborescens & & $\mathrm{x}$ & $\mathrm{x}$ & \\
\hline & Corynepteris (Alloiopteris) sp. & & & & $\mathrm{x}$ \\
\hline & Senftenbergia plumosa & & $\mathrm{x}$ & $\mathrm{x}$ & $\mathrm{x}$ \\
\hline Noeggeratiopsida & Noeggheratia cf. tenuistriata & & $\mathrm{x}$ & & \\
\hline \multirow[t]{29}{*}{ Pteridospermopsida } & Sphenopteris sp. & & & & $\mathrm{x}$ \\
\hline & Eusphenopteris cf. neuropteroides & & & & $\mathrm{x}$ \\
\hline & Dicksoniites cf. pluckeneti & & $\mathrm{x}$ & & \\
\hline & Mariopteris latifolia & & $\mathrm{x}$ & & \\
\hline & Mariopteris cf. lobatifolia & & & & $\mathrm{x}$ \\
\hline & Mariopteris cf. sauveurii & & & & $\mathrm{x}$ \\
\hline & Karinopteris dernoncourti & & & & $\mathrm{x}$ \\
\hline & Neuropteris attenuata & & $\mathrm{x}$ & & \\
\hline & Neuropteris flexuosa & & $\mathrm{x}$ & & \\
\hline & Laveinopteris tenuifolia & & $\mathrm{x}$ & & \\
\hline & Alethopteris sp. (cf. grandinii) & & & & $\mathrm{x}$ \\
\hline & Alepthopteris sp.A & & & & $\mathrm{x}$ \\
\hline & Alepthopteris sp.B & & & & $\mathrm{x}$ \\
\hline & Neuralethopteris cf. larischii & & & & $\mathrm{x}$ \\
\hline & Cf. Odontopteris sp. & & & & $\mathrm{x}$ \\
\hline & Paripteris gigantea & & $\mathrm{x}$ & & \\
\hline & Paripteris linguaefolia & & & & $\mathrm{x}$ \\
\hline & Linopteris obliqua & & & $\mathrm{x}$ & $\mathrm{x}$ \\
\hline & Linopteris neuropteroides & & $\mathrm{x}$ & $\mathrm{x}$ & \\
\hline & Cyclopteris sp. & & & $\mathrm{x}$ & \\
\hline & Palaeoweichselia defrancei & & $\mathrm{x}$ & & \\
\hline & Aulacopteris vulgaris & & $\mathrm{x}$ & & \\
\hline & Hexagonocarpus sp. & & & & $\mathrm{x}$ \\
\hline & Trigonocarpus bernardi & & $\mathrm{x}$ & $\mathrm{x}$ & \\
\hline & Trigonocarpus sp. & & & & $\mathrm{x}$ \\
\hline & Carpolithus sp. & & & & $\mathrm{x}$ \\
\hline & Carpolithes coniformis & $\mathrm{x}$ & & & \\
\hline & Codonospermum sp. & & $\mathrm{x}$ & & \\
\hline & Rhabdocarpus costatus & & $\mathrm{x}$ & & \\
\hline \multirow[t]{8}{*}{ Cordaitopsida } & Cordaites sp. & & & & $\mathrm{x}$ \\
\hline & Cordaites principalis & $\mathrm{x}$ & & $\mathrm{x}$ & \\
\hline & Cordaites palmaeformis & & $\mathrm{x}$ & $\mathrm{x}$ & \\
\hline & Cordaites borassifolius & & $\mathrm{x}$ & & \\
\hline & Dorycordaites palmaeformis & & $\mathrm{x}$ & & \\
\hline & Cordaicarpus sp. & & & $\mathrm{x}$ & \\
\hline & Aspidiopsis aff. coniferoides & & $\mathrm{x}$ & & \\
\hline & Cordaicarpus cordai & & $\mathrm{x}$ & & \\
\hline
\end{tabular}




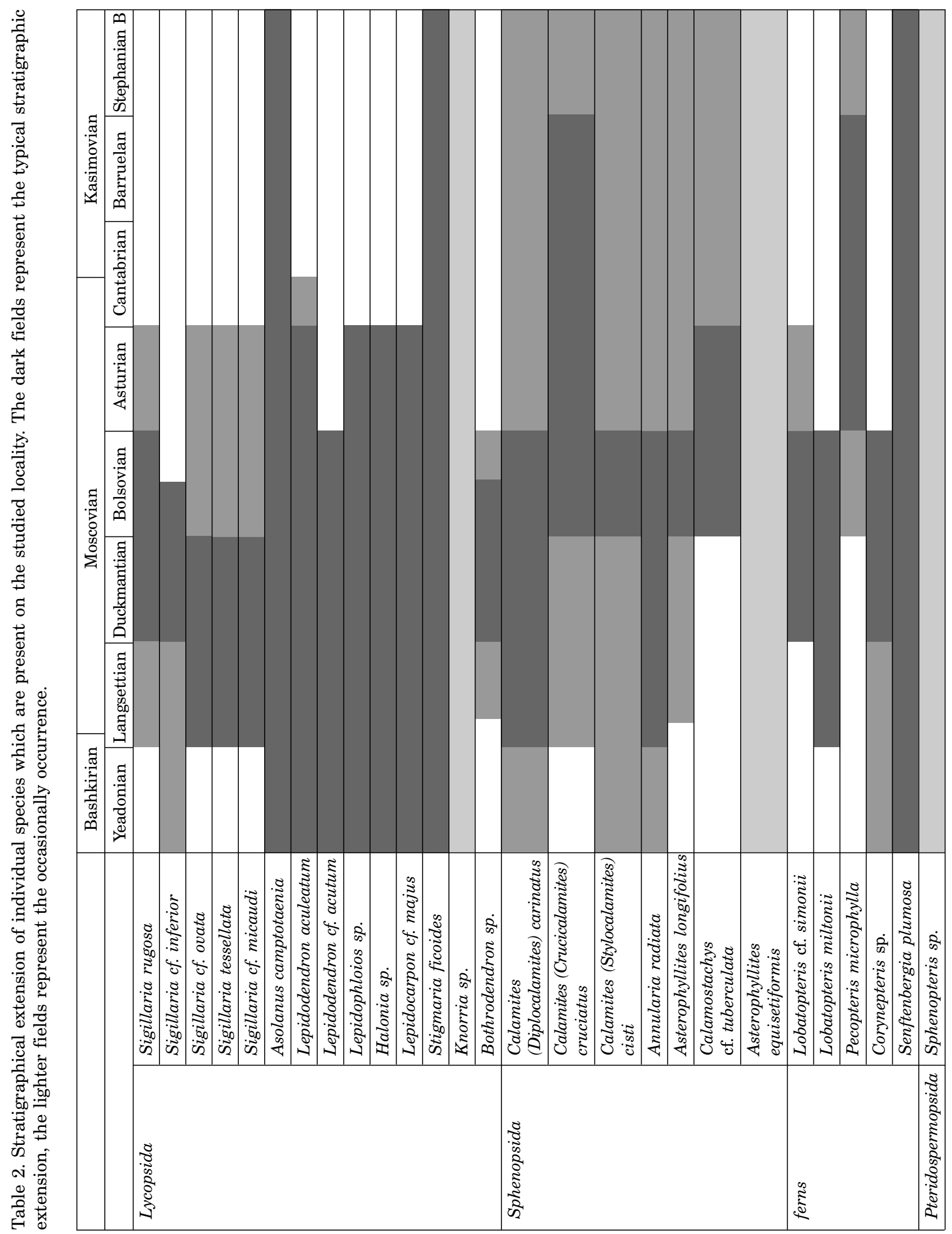




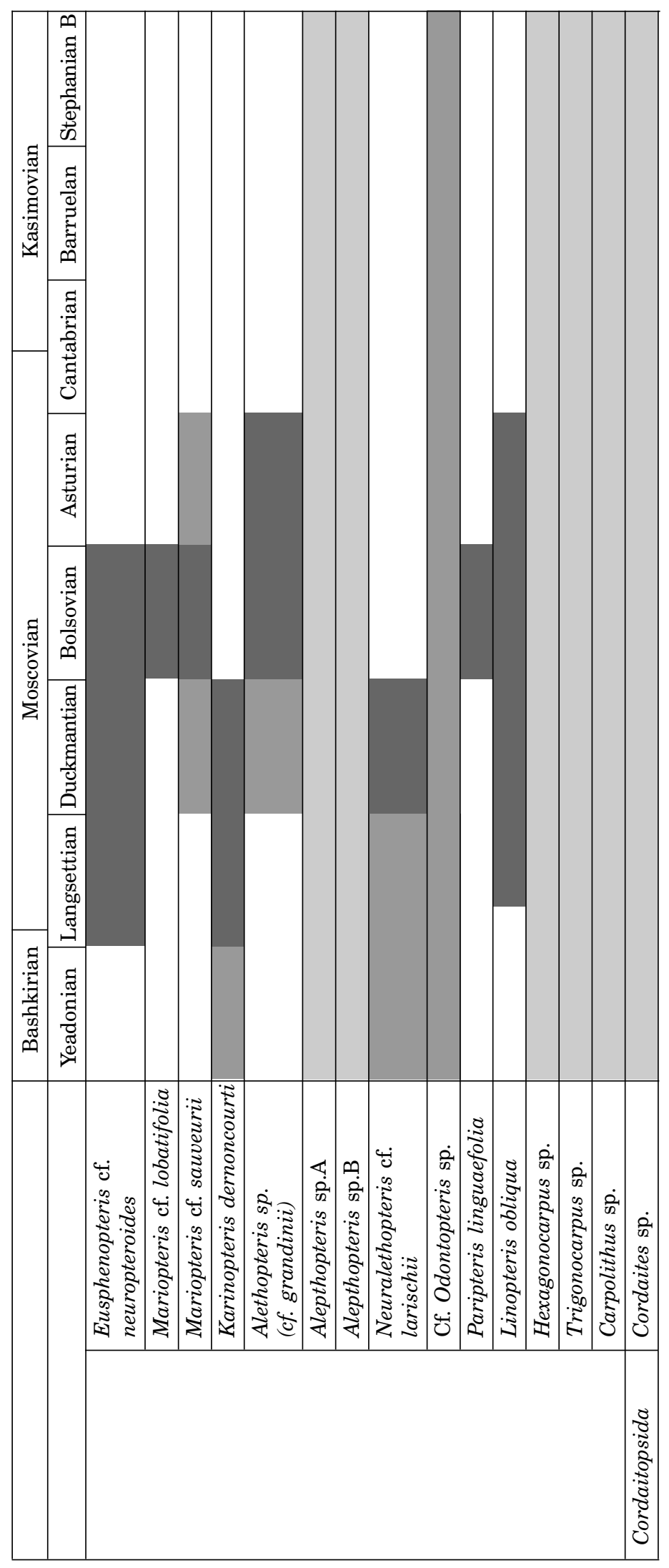




\section{REFERENCES}

Alvarez-Ramis, C.A., Doubinger, J., Germer, R. 1978. Die Sphenopteridischen Gewächse des Saarkarbons, 1. Teil: Sphenopteris sensu stricto. Palaeontographica, Abt. B, 165, (1-3), 1-42.

Ameron, H.W., 1975. Die Eusphenopteridischen Pteridophyllen aus der Sammlung des Geologischen Bureaus in Heerlen, unter Besonderen Berücksichtigung Ihrer Stratigraphie Bezüglich des Südlimburger Kohlenreviers. Mededelingen Rijks Geologische Dients, Series C, 17, 1-208.

Bateman, R.M., DiMichele, W.A., Willard, D.A. 1992. Experimental cladistic analysis of anatomically preserved arborescent lycopsids from the Carboniferous of Euramerica: an essay on paleobotanical phyllogenetics. Annals of the Missouri Botanical Garden, 79, 500-559.

Bek, J., Pšenička, J. 2001. Senftenbergia plumosa (Artis) emend. and its spores from the Carboniferous of the Kladno and Pilsen Basin, Bohemian Massif, and some related and synonymous taxa. Review of Palaeobotany and Palynology, 116, 213-232.

Boersma, M. 1972. The Heterogeneity of the form genus Mariopteris Zeiller. A comparative morphological study with special reference to the frond composition of West-European Species. 172 pp. Drukkerij Elinkwijk, Utrecht.

Boulay, N. 1876. Le terrain houiller du nord de la France et ses végétaux fossiles. Lille, I-II, 1-74.

Boureau, E. 1964. Traité de Paléobotanique, Tome III, Sphenophyta, Noeggerathiophyta. 544 pp. Masson et $\mathrm{C}^{\mathrm{ie}}$, Paris.

Brongniart, A. 1828. Prodrome d' une histoire des végétaux fossiles. Dictionaire des sciences naturelles., 57, $223 \mathrm{pp}$.

Casati, P. 1978. Tettonismo e sedimentazione nel settore occidentale delle Alpi Meridionali durante il tardo Paleozoico, il Triassico e il Giurassico. Rivista Italiana di Paleontologia e Stratigrafia, 84, 313-326.

Corsin, P. 1951. Bassin houiller de la Sarre et de la Lorraine, I. Flore Fossile 4me Fascicule Pécoptéridiées. 370 pp. Études des Gîte Minéraux de la France.

Crookall, R. 1966. Fossil Plants of the Carboniferous Rocks of Great Britain (second edition). Memoirs of the Geological Survey of Great Britain. Palaeontology, Vol. IV (4), 1-571.
Crookall, R. 1976. Fossil Plants of the Carboniferous Rocks of Great Britain (second edition). Memoirs of the Geological Survey of Great Britain. Palaeontology, Vol. IV (7), 857-956.

Dalinval, A. 1960. Les Pecopteris du Bassin houiller du Nord de la France. Theses, Université de Lille, la Faculté des Sciences, France, DouriezBataille, $222 \mathrm{pp}$.

Danzé, J. Corsin P., 1953. Contribution a 'l etude des Mariopteridées du Nord de la France. Études Géologiques pour l'Atlas de Topographie Souterraine publiées par le Service Géologique des H.B.N.P.C. 1(1): 269 pp.

Deltenre, H, 1924. Les Sigillaries des Charbonnages de Mariemont. (Mémoire posthume publié par Jean de Dorlodot). Mémoire de Institut Université de Louvain, Vol. III, 1-116.

DiMichele, W.A., Phillips, T. L. 1994. Paleobotanical and paleoecological constraints on models of peat formation in the Late Carboniferous of Euramerica. Palaeogeography, Palaeoclimatology, Palaeoecology 106 (1-4), 39-90.

Escher, B.G. 1911. Über die prätriasische Faltung in den Westalpen mit besonderer Untersuchung des Carbons an der Nordseite des Toedi (Bifertengraetli) : mit einem Anhang über das Scheidnössli bei Erstfeld im Reusstal und das Carbon von Manno bei Lugano. 174 pp. PhD thesis on Proefschrift Polytechnische Schule Zürich.

Fissunenko, O.P., Laveine, J.P. 1984. Comparaison entre la distribution des principalese spécesgiudes végétales du carbonifére moyen dans le bassin du Donetz (URSS) et les bassins du Nord-Pas.de-Calais et Lorraine (France). C.R. IXe International Stratigraphy Geology Carboniferous Congress, Washington-Urbana, 1979, 1, 95-100.

Gaetani, M., Gianotti, R., Jadoul, F., Ciarapica, G., Cirilli, S., Lualdi, A., Passeri, L., Pellegrini, M., Tannoia, G. 1986. Carbonifero superiore, Permiano e Triassico nell area Lariana. Memorie della Societŕ Geologica Italiana, 32, 5-48.

Galtier, J., Scott, A.C. 1979. Studies of paleozoic ferns: on the genus Corynepteris . A redescriptions of the type and some other European species. Palaeontographica, Abt. B., 170, 81-125.

Heer, O. 1876. Flora fossilis Helvetiae, 47. Verlag von J. Wurster and Co., Zurich, 41-42. 
Hirmer, M. 1927. Handbuch der Paläobotanik. 7081 pp. R. Oldenburg Verlag., Munich.

Jongmans, W.J. 1950. Mitteilungen zur Karbonflora der Schweiz. I. Eclogae Geologicae Helvetiae 43 (2), 95-104.

Jongmans, W.J. 1960. Die Karbonflora der Schweiz. Beiträge zur geologiche Karte der Schweiz (NF) 108, 1-97.

Jongmans, W., Dijkstra, S. J. 1960. Fossilium Catalogus, II. Plantae, Filicales, Pteridospermae, Cycadales. Uitgeverij Dr. W. Junk, Gravenhage, 44 (17), 1453-1596.

Josten, K. H. 1983. Die fossilen floren im Namur des Ruhrkarbons. Fortschritte in der Geologie von Rheinland und Westfalen, 31, 1-327.

Josten, K. H. 1991. Die Steinkohlen-Floren Nordwestdeutschlands. Fortschritte in der Geologie von Rheinland und Westfalen, 36, 1-434.

Kessler, P. 1916. Die Alethoptreriden und Mariopteriden der Saarbrückener Schichten des Saarbeckens. Zeitschrift der Deutschen Geologischen Geselschaft, 67, 69-84.

Kidston, R. 1925. Fossil plants of the Carboniferous Rocks of Great Britain. Memoirs of the Geological Survey of Great Britain. Palaeontology, Vol. II, (6), 523-670.

Kidston, R., 1903. Fossil plants of the Carboniferous Rocks of Canobie. Transactions of the Royal Society Edinburgh, Vol. XL, p. 765.

Laveine, J. P., Lemoigne, Y., Zhang, S.,Z. 1993. General characteristics and palaeobiogeography of the Parispermaceae (genera Paripteris Gothan and Linopteris Presl), Pteridosperms from the Carboniferous. Palaeontographica, B, 230 (1-6), 81-139.

Lehner, P. 1952. Zur Geologie des Gebietes der Denti della Vecchia,des M. Broglia, des M. Brč, und des M. San Salvatore bei Lugano. Eclogae Geologicae Helvetiae, 45, 86-159.

Magnani, M. 1946. Sulla presenza di terreni spettanti al Carbonifero nei monti di Menaggio (Valle Sanagra). Atti della Regia Accademia delle Scienze di Torino, 80, I, 199-206.

Němejc, F. 1947. The Lepidodendraceae of the coaldistricts of Central Bohemia. Sborník Národního Musea 7, B, 2, 45-87.

Němejc, F. 1951. Studies on the Sigillariae of the Lower grey beds of the Carboniferous in central Bohemia. Sborník Národního musea v Praze. Vol. VII B, 2, 1-59.
Němejc, F. 1953. Úvod do floristické stratigrafie kamenouhelných oblastí v ČSR. 173 pp. Československá akademie věd, Praha.

Pittau, P., Del Rio, M., Cotza, F., Ronchi, A., Santi, G., Gianotti, R. 2008. Pennsylvanian miospore assemblages from the Bčdero Section, Varese, Italian Southern Alps. Revue de micropaléontologie, 51, 133-166, doi: 10.1016/j.revmic.2007.11.001.

Pšenička, J., Bek, J. 2003. Cuticles and spores of Senftenbergia plumosa (Artis) Bek and Ps`enic $>k a$ from the Carboniferous of Pilsen Basin, Bohemian Massif. Review of Palaeobotany and Palynology, 125, 299-312.

Pšenička, J., Opluštil, S. 2011. Fossil flora from the Üjez u Svatého Kříže Coalfield (Bolsovian, Pennsylvanian), Radnice basin, Czech Republic. Folia Musei Rerum Naturalium Bohemiae Occidentalis Geologica et Paleobiologica 45 (1-2), 61 - 93.

Pšenička, J., Bek, J., Cleal, C.J., Wittry, J., Zodrow, E.L. 2009. Description of synangia and spores of the holotype of the Carboniferous fern Lobatopteris miltoni, with taxonomic comments. Review of Palaeobotany and Palynology, 155, 133-144.

Purkyňová, E. 1976.Makrofloristická korelace svrchnonamurských vrstev v podbeskydské pánvi (hornoslezská pánev). Časopis Slezského muzea, Opava (A), 24,185-189.

Ronchi, A., Kustatscher, E., Pittau, P., Santi, G. 2012. Pennsylvanian floras from Italy: an overview of the main sites and historical collections. Geologia Croatica, 65(3), 299-322.

Selva, A. 2009. Alla ricerca dei fossili nei monti e nelle cave del Lario e del Ceresio. 237 pp. Maggioli Editore, Litografia Titanlito s.a. Dogana.

Sordelli, F. 1896. Flora fossile insubrica. Studi sulla vegetazione in Lombardia durante $i$ tempi geologici. 298 pp. Tipografia Cogliati Milano.

Stadler, G., Teichmuller, M., Teichmuller, R. 1976. Zur geotermischen Geschichte des Karbons von Manno bei Lugano des "Karbons" von Falletti (Sesiazone der Westalpen). Neues Jahrbuch für Geologie und Paläontologie - Abhandlungen, 152, 177-198.

Šimůnek, Z. 2007. New Classification of the genus Cordaites from the Carboniferous and Permian of the Bohemian Massif, based on cuticle micromorphology. Sborník Národního muzea v Praze, rada B-př́rodní vědy - Acta Musei Nationalis Prague, Ser. B. Historia Naturalis 62, 3-4, 97-210. 
Šimůnek, Z. 2010. Cuticles of Paripteris Gothan, 1941 (Pteridospermopsida) from the Westphalian of Poland. Bulletin of Geosciences 85, 2, 353-360.

Tenchov, Y.G., Cleal, C.J. 2010. Neuralethopteris foliage (Medullosales) in the Carboniferous of the Dobrudzha Coalfield, Bulgaria. Review of Palaeobotany and Palynology, 158, 298-307.

Venzo, S. 1951. Les gisements nouveaux du Carbonifčre (Westphalien) dans les Alpes Lombardes. C. R. du 31e Congrčs de Stratigraphie et de Géologie du Carbonifčre, Herleen 1951, 647649.

Venzo, S., Maglia, L. 1947. Lembi carboniferi trasgressivi sui micascisi alla „Fronte sedimentaria subalpina" del Comasco (Acquaseria di MenaggioBocchetta di S. Bernardo) e del Varesotto (Bčdero). Atti della Societŕ Italiana di Scienze Naturali, 85/86, 33-70.

Wagner, R. H. 1964. Stephanian floras in NW. Spain, with special reference to the Westphalian D - Stephanian A boundary. Cinquičme Congrčs International de Stratigraphie et de Géologie du Carbonifčre, Paris: 9-12 septembre 1963. Compte Rendu. 835-851.
Wagner, R. H. 1968. Upper Westphalian and Stephanian species of Alethopteris from Europe, Asia Minor, and North America. Mededelinge van de Rijks Geologisches Dienst, Serie C., III1, 6, 1-188.

Wagner, R. H. 1984. Megafloral zones of the Carboniferous. Compte rendu 9e Congrčs International de Stratigraphie et de Géologie du Carbonifčre,(Washington 1979). 2, 109-134

Zhang, S., Huo, F., Cao, J., Liu, Z., Laveine, J. P. and Lemoigne, Y. 1993. The Carboniferous flora of Zhongning district, Ninxia Region, North China. Revuew of Paleobiology, 6, 1-93.

Zodrow, E.L., Tenchov, Y.G., Clelal, C.J. 2007. The arborescent Linopteris obliqua plant (Medullosales, Pennsylvanian). Bulletin of Geosciences 8, $1,51-84$.

Zodrow, E. L., Cleal. C. J. 1998. Revision of the pteridosperm foliage Alethopteris and Lonchopteridium (Upper Carboniferous), Sydney Coalfield, Nova Scotia. Canada. Palaeontographica, Abteilung B, 247, 65-122. 